MPRYGALE'S

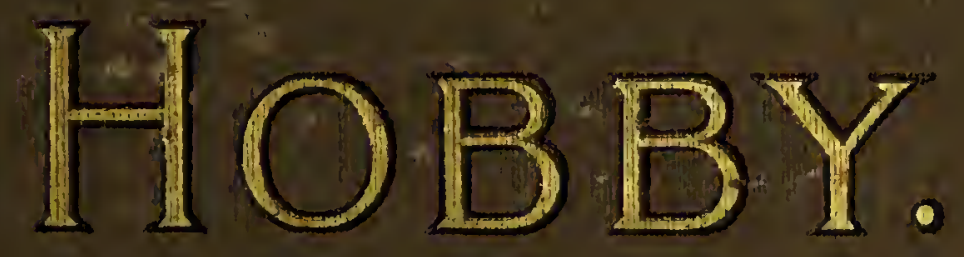

\title{
DARLEY DALE
}

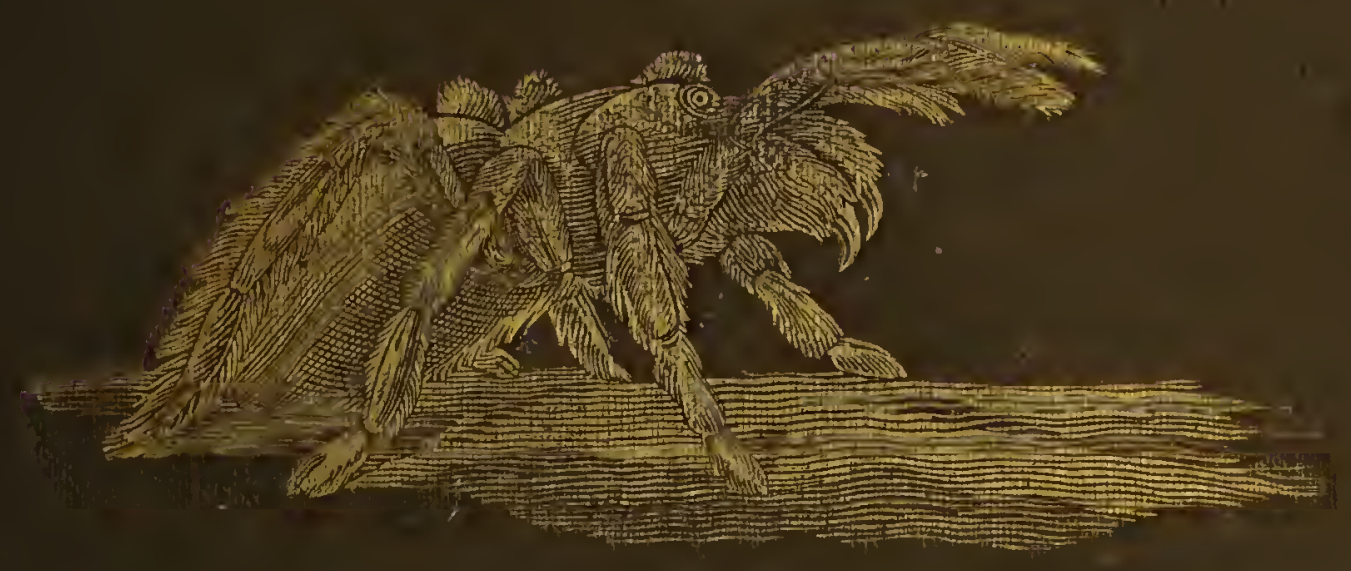

LlLustrated BY C. WHYMPER, 



Alfed Barold Bastir 1890 


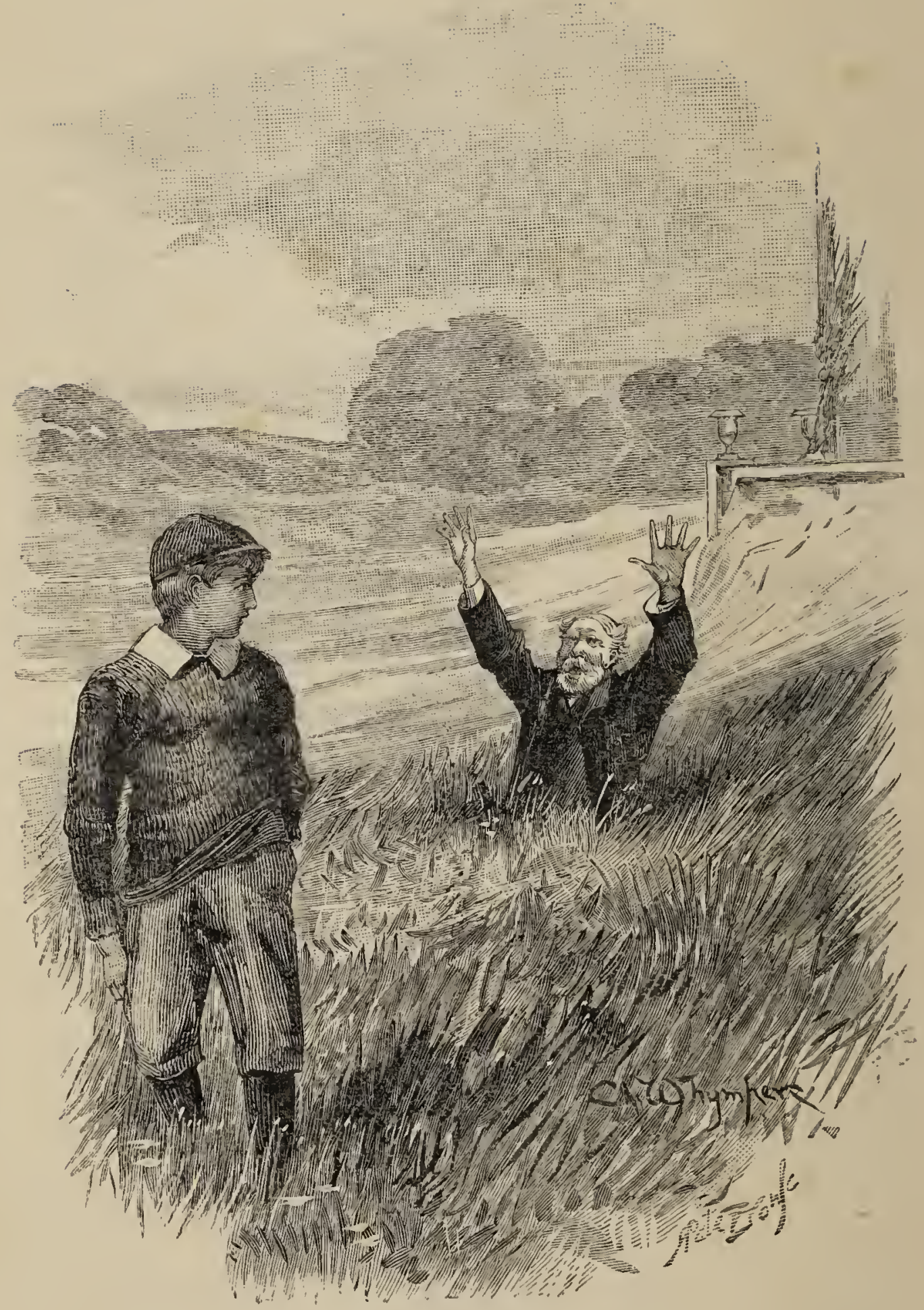

[See page 12. 


\section{MR. MYGALE'S HOBBY}

\section{A Story about Spions}

BY THE AUTHOR OF

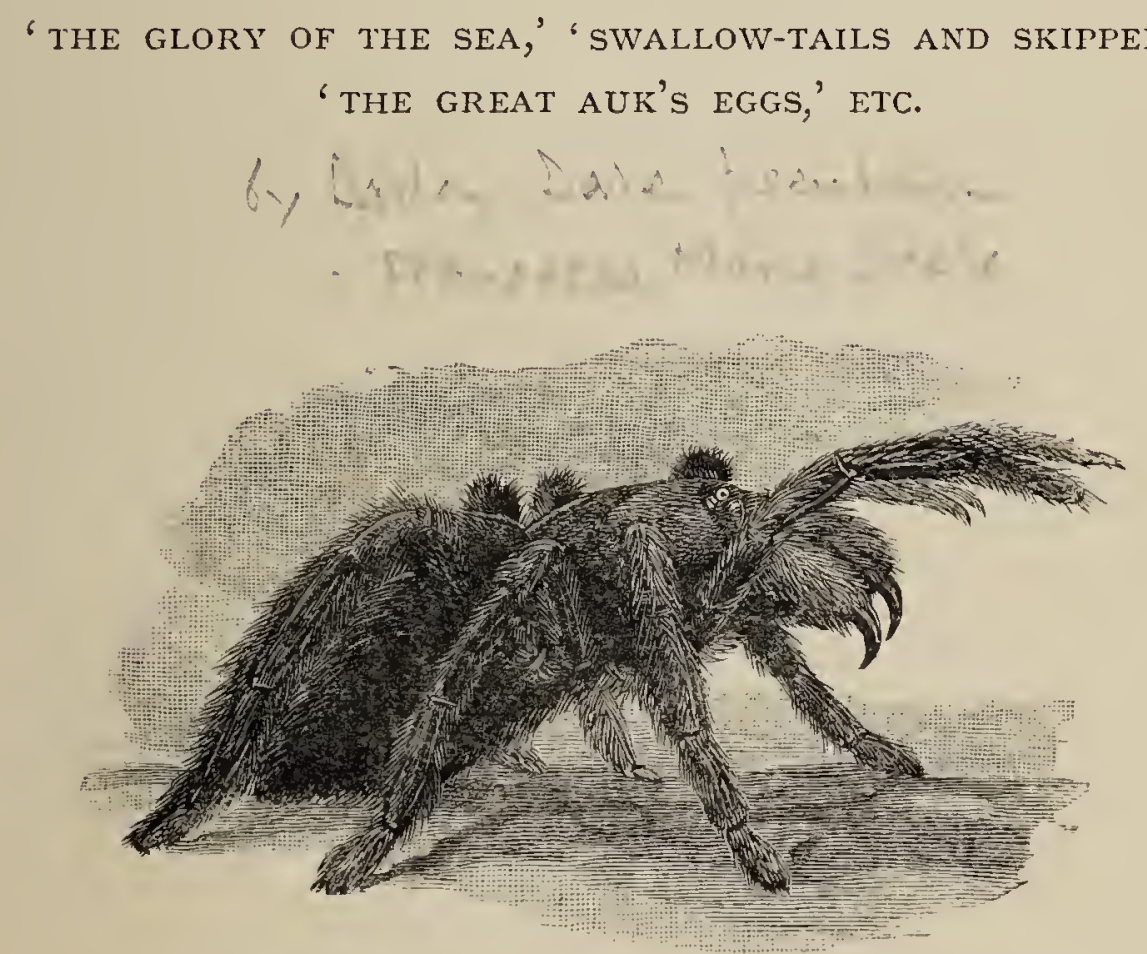

THE RELIGIOUS TRACT SOCIETY

56 Paternoster row, $6_{5}$ st. Paul's ChUrChyard AND $\mathrm{I}_{4}$ PICCADILLY 
(1) $\mathfrak{x} \mathfrak{\operatorname { a r d }}$

HORACE HART, PRINTER TO THE UNIVERSITY 


\section{CONTENTS.}

CHAPTER I. PAGE

A CApture . . . . . . . . . . . 7

CHAPTER II.

The Return of the Prisoner • • • • • . $\quad 27$

CHAPTER III.

A Practical Joke . . . . . . . . . . 50

CHAPTER IV.

The Story of Tile Portrait . . . . . . 70

CHAPTER V.

Plans Frustrated • • • • • • • • • 93

CHAPTER VI.

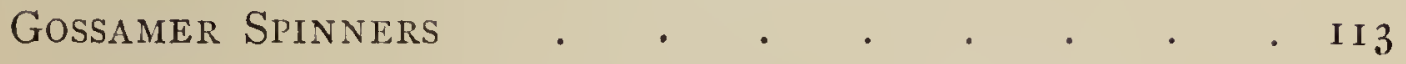

CHAPTER VII.

OFF to THE CAPE . . . . . . . . . .

CHAPTER VIII.

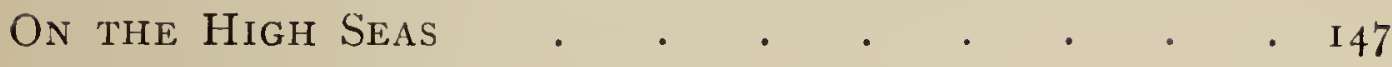

CHAPTER IX.

FOREIGN SPIDERS . . . . . . . . . . . . 166

CHAPTER X.

Sir Richard SUTTON . . . . . . . . . I75

APPENDIX . 



\section{CHAPTER I.}

\section{A CAPTURE.}

"Will you come into my parlour?"

Said the spider to the fly;

"'Tis the prettiest little parlour

That ever you did spy."

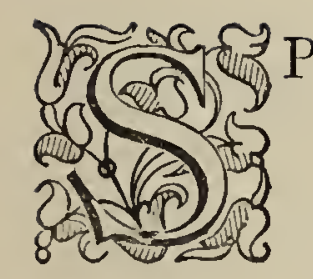

PIDERS !

They were his hobby. He studied them, he collected them, he hunted them, he travelled in search of them, he watched them living, he kept them in glass-cases when dead, he marvelled at them, he loved them.

Yes, strange as it may appear, he loved spiders, and what is even stranger, it is exceedingly doubtful whether he loved anything else. Report said he did not, unless he loved himself; and his neighbours maintained this was impossible, so exceedingly unlovable did he seem to them to be.

Poor Mr. Mygale! He deserved to be pitied, and 'pity,' we know, 'is akin to love,' for he had not a single relative in the world nearer than a distant cousin. 
He had no friends; he lived alone-no, not alone ; but with his spiders. He never had any visitors, he never paid any visits, indeed, he seldom went out, except in his own grounds; but he sometimes was absent from home for months at a time, for he travelled a good deal, always with the same object in view, and that object was spiders.

But poor Mr. Mygale was not poor in this world's goods; on the contrary, he was rich. His house, and the park in which it stood, were his own, and he had a large income; nevertheless, he lived very simply; he kept no large establishment, all the house (with the exception of two or three rooms for his use, and two or three more for the man and his wife who were his only servants) was shut up, and only opened occasionally to be aired and cleaned. He kept no horses or carriages; the garden was neglected, except about half-an-acre of kitchen garden, which the man-servant kept in order. He had no dogs, no pets of any kind, always excepting his spiders.

He was a little man, very thin, and always dressed in a very tight suit of black clothes; in the summer these clothes were made of alpaca, in the winter, of velvet; in the evening, both summer and winter, of cloth, but always black, and always so tight that one wondered first how he got into them, and secondly how, having achieved that feat, he ever got out of them again. He was ugly, decidedly ugly: he had small eyes with shaggy eyebrows, a short thick nose, 
and a large mouth, partially hidden by a rather ragged, grizzly moustache and beard; but he had beautiful hands, small, well-shaped, and white as a lady's. Such was Mr. Mygale.

His servant, Martin, was a great contrast to his master, for Martin was a tall handsome man, with a genial manner and a fine open countenance; and Mrs. Martin, who was cook and housekeeper and general servant all in one, was a comely, motherly-looking woman, who waged an incessant war with her master on the subject of cobwebs, of which wonderful structures they took opposite views. Mrs. Martin regarded cobwebs as things to be swept away indignantly, as soon as observed, though she knew it was as much as her place was worth to destroy one, if her master discovered the act; for Mr. Mygale-considered cobwebs the most precious things in his house, after his spiders, and would on no account suffer one to be destroyed.

'Martin,' he would say, 'your best black silk dress, nay, the best silk dress ever turned out of a factory, is coarse, common trumpery, in comparison with a spider's web; that thread, so fine you can scarcely see it with the naked cye, is five-fold; why, the silk of which your dress is spun a spider would scorn, as you would sackcloth.'

And Martin, who boasted that her silk dress would stand alone, would give an indignant snort, shut the door with unnecessary violence, and sail majestically into the kitchen, to report to her husband the insult 
done to her Sunday best dress, and express her opinion that her master was mad.

Perhaps she was right. We are all mad on some points, doctors tell us. Mr. Mygale's point was spiders. He was undoubtedly very eccentric, and Mrs. Martin was not singular in her opinion, which was shared by many people in the neighbourhood. Among his eccentricities, he had a trap-door in his garden which opened into an underground passage or tunnel, leading into his study; this terminated in a small spiral staircase, at the top of which was the trap-door; this door was a work of art, and was made on the model of the Trap-door spider's. It was in some long grass, about twenty yards from the study window, and when closed was so effectually concealed by the grass that it was almost impossible to discover it. Another of Mr. Mygale's eccentricities was, that he allowed no one to venture inside the park gates. The postman and tradespeople left his letters and all that he required at the lodge, but never ventured inside the gates. Had they done so, they would have been dismissed at once. Boards announcing that all trespassers would be prosecuted were plentifully posted about the outer side of the park, and every entrance was carefully locked and chained, and high wooden palings surrounded it.

Judge then of Mr. Mygale's amazement one afternoon, when, from his study window, he beheld a small boy, perhaps ten years old, strolling leisurely through 
the long grass towards the house, with his hands in his pocket, his cap well on the back of his head, which was thrown rather high in the air, as the boy, with eyes of blue, gazed into the sky, and whistled a tune with his red lips. Two things were evident to the most casual beholder; one, that the boy was a gentleman; the other, that he was beautiful. A third thing struck Mr. Mygale, namely, that he was, without exception, the boldest, most audacious little scamp it had ever been his lot to set eyes on. Were there not boards without end all over the park threatening trespassers with prosecution? Were not all the gates securely fastened? Was it not well known that under no pretext whatever was any one admitted inside the park?

And yet here was this little whipper-snapper, ten years old, marching nonchalantly about as if the place were his own, in utter defiance of all notices, threats, locks, and bars, whistling; yes, there was no doubt of it, positively whistling his defiance.

Mr. Mygale almost danced with rage. His first impulse was to open the window, step out, seize my lord by his collar, flog him, and send him about his business; but second thoughts are often best, and on second thoughts he decided to pursue an entirely different course. With a grim chuckle he opened a trap-door in his room, and disappeared down a wooden staircase, shutting the door after him. In a few minutes, an unearthly snarl or yell, sounding like 
the monosyllable 'yah,' caused the boy, who had been slowly advancing, to turn abruptly round; and to his amazement he saw the head and a piece of the shoulders of Mr. Mygale emerging from the earth: as he stood watching this remarkable phenomenon, the head and shoulders suddenly disappeared, and the trap-door closed with a little thud.

'Jupiter!' cried the boy aloud, 'that's queer, and no mistake; a real hobgoblin, as I live; I must see if I can't discover his hole.'

So saying, he walked in the direction of the apparition, and wandered about among the long grass, searching carefully for the trap-door, but in vain; he could not discover a trace of it. He was about to give up the search, when, a few feet from the spot where he was standing, the door opened a second time, the head and shoulders of Mr. Mygale appeared, with uplifted arms, which he shook in anger at the boy, at the same time gnashing his teeth and frowning furiously. $\mathrm{He}$ then disappeared a second time. If he hoped to frighten the intruder, he was sorely disappointed, for instead of being frightened the boy went into fits of laughter, and when he had partially recovered himself, jumped about the grass, laughing and shouting.

'Bravo, Hobgoblin! bravo! do it again, there's a good fellow; this is prime!'

No response was made to this appeal, and once again the boy set to work to try and discover the trap-door, but with no better success. He went down 
on his hands and knees, and carefully examined the turf, but not a trace of an opening could he find. $\mathrm{He}$ thumped the earth with his little fist to see if it was hollow, he shouted appeals to the hobgoblin to favour him with one more glimpse of his person, but all in vain; and he was about reluctantly to abandon his search, when he felt a small hand firmly grasp one of his feet and pull him backwards.

The boy; who was lying on his face, struggled, and turned round to look at his captor, but his efforts to escape were in vain; in a few moments he found himself sitting upright on the turf, his legs dangling down into the hole he had been trying to find, while his hobgoblin held open the trap-door with one hand, and grasped him by the shoulder, as in a vice, with the other.

For a moment the boy was startled, and the colour vanished from his cheeks, to Mr. Mygale's intense satisfaction; but it was only for a minute, and then the little prisoner, whose young face was very close to Mr. Mygale's ugly, wrinkled countenance, pealed forth one of his merry laughs, and clapped his hands with delight.

'The young rascal! Why, he is not frightened,' exclaimed Mr. Mygale, in amazement.

'Frightened! I am never frightened; I don't know the feeling; but, I say, it is awfully clever of you. Do tell me how you have made such a lovely trap-door, and where it leads to. May I come down and see?' 
Mr. Mygale's astonishment changed to admiration at the boy's coolness, but he could not resist the temptation to make another attempt at frightening his prisoner, so frowning prodigiously, and accompanying his words with several little shakes, he said in his gruffest voice :-

'May you come down? indeed, you will come down, young man; and, what is more, you will stay down. Take a farewell look at the blue sky and the green grass, and then down with you into the bowels of the earth, for good and all, with your hobgoblin.'

'You are not a hobgoblin; there are no such things. You must be Mr. Mygale, who, the people say, is mad; and I should like to come down with you very much indeed. I am not a bit afraid; I am sure you won't hurt me; you are only in fun.'

'In fun, am I? We'll see about that before you leave me again. If I am Mr. Mygale, as you think, it is a very bad look-out for you, for he knows what to do with trespassers who disregard his warnings,' said Mr. Mygale fiercely, but with a fierceness he was far from fecling:

'Well, you see, I am not exactly a trespasser, because I persuaded the lodge-keeper, who is a friend of mine, to let me in. It is all my fault, you know, not his at all, so you must not be angry with him,' replied the child in an apologetic tone. 
'I'll square accounts with you first, young sir, and then direct my attention to your friend the lodgekeeper. Come along; get on to my back, and hold your head as low as you can, or you'll get it broken sooner than you expect.'

The boy obeyed, swung himself on to Mr. Mygale's shoulders, and gave a shout of delight as the trapdoor closed upon them. He felt his captor descend a few stairs until they reached the tunnel, in which stood a lantern. This Mr. Mygale picked up, and, with his prisoner on his shoulders, walked through the passage till they reached the foot of the little spiral staircase which led into his study. Here Mr. Mygale paused, put the boy down on the ground, and told him to go first up the staircase, while he followed close upon him, unbolted the trap-door, and they found themselves in the study.

It was a good-sized room, two sides of which were lined with books from ceiling to floor; the other two sides were almost covered with glass cases, containing spiders and spiders' nests. A handsome microscope and cases of slides stood near the window, and on a large table in the centre of the room were more cases containing spiders, spiders' eggs, and cocoons, while cobwebs plentifully adorned the ceiling and every available nook and cranny.

The boy gazed round him with mingled feelings of astonishment, delight, and disgust-all of which by turns were expressed on his face. 
'Well, sir,' said Mr. Mygale, after a few minutes' silence, during which the child looked about him, ' may I ask what is your opinion of my den ?'

' I think it is a lovely place, only it is so dreadfully dirty; it is all over cobwebs. But, you see, you are a bachelor, so you have no one to look after your servants. Now if mother were here, she would ring the bell and have all those horrid cobwebs, and the spiders that spin them, swept away in five minutes. I could do it myself for you if I only had a broom-they spoil the room,' he added, glancing at the library steps, on which, doubtless, he proposed to conduct his sweeping.

'Disturb my cobwebs! Boy, it is as much as your life is worth! I value them more than anything I possess, except my spiders,' exclaimed Mr. Mygale, inwardly regretting that he had been guilty of such folly as bringing this young Philistine into his den.

' I wonder if he really is mad, as the people say; I had better be careful not to offend him,' thought the child, and aloud he said apologetically, raising his blue eyes to his strange host's face; 'I beg your pardon, I didn't know you really liked cobwebs. I hate them, and I think spiders the nastiest insects living:'

'Insects! they are not insects at all, boy. What an ignorant child you are not to know that!'

'Spiders not insects?-what are they then? They are not birds, and they are not animals. I don't 
see what else they can be, unless they are reptiles; they are nasty enough to be classed with toads and snakes.'

'Boy, your ignorance is appalling. Every living creature that moves is an animal. Perhaps you will be surprised to hear that a fly is the average size of all animals. I dare say you don't believe me.'

'Yes, I do. I am sure you know; but it seems, you see, impossible just at first, because elephants are such very big things and flies so very small. I should have thought a cat was about the average size of all animals. Of course, I was quite wrong.'

'You were,' said Mr. Mygale, dryly; 'but I don't suppose the Infusoria, by which I mean microscopic animals, have yet come under your notice.'

'Microscopic animals! No, I don't know anything about them; but I should like to know what spiders are if they are not insects.'

'They are animals belonging to a class called the Arachnida. A perfect insect is divided into three segments, the head, the thorax, and the abdomen; it has wings, only two eyes; it breathes by spiracles, or breathing-holes, and the head is furnished with two antenna. Now just come here and look at this spider; look at its body first, and you will see it is divided into two pieces only, instead of into three, like an insect; the head and the thorax are united into one piece, which is called the cephalo-thorax (cephale being the Greek for head, and thorax for 
chest); the larger piece is the abdomen. It has no wings; it has, however, eight legs, whereas insects have seldom more than six. This particular spider has only six eyes, as you may see if you look through this magnifying glass; but, as a general rule, spiders have eight eyes, all of which are simple eyes, as distinct from compound, and the various ways in which these eyes are arranged form the distinguishing marks of the different genera. They shine in the dark like cats' eyes, and I believe spiders are able to see as well by night as by day. The eyes are sometimes mounted on little tubercules above the cephalothorax. The upper side of this cephalo-thorax is called the shield, the under-covering the breastplate; the eyes are placed on the front part of the shield. The eight legs, which in all British spiders, and nearly all foreign, consist of seven joints, are inserted in a sort of circle round the cephalo-thorax; they are generally hairy, and their length varies very much in the different genera. The feet have two or three claws : when there are only two, they frequently have a little brush underneath them; when there are three, they are of various sizes. Now the shape of the cephalo-thorax varies in different spiders: sometimes it is oval, sometimes nearly square, sometimes round, sometimes heart-shaped. The abdomen also varies very much in shape; it is either flat, or nearly round like a globe, or cylindrical, or egg-shaped, or angular; sometimes it is hairy, sometimes destitute 
of hairs, sometimes glossy; and the same may be said for the breastplate and the shield.'

During this long speech the boy had been listening most attentively, and looking eagerly through the magnifying glass at the different parts Mr. Mygale pointed out; while, as for the latter, he was so intensely interested in his subject that it never occurred to him to fear he was tiring his listener.

'Are you tired, boy?' he exclaimed, suddenly and sharply.

'Oh, no; please tell me some more. I believe I shall end in almost liking spiders. That would be odd, wouldn't it?' And he threw up his golden head, and laughed one of his merry, happy laughs.

'It would,' said Mr. Mygale, grimly; 'but if you wish to hear more, you must wait till I get a stronger magnifying glass.-This will do. Now, look here; just below the eyes, and above the mouth, you will see two little claws; these are the falces, or poison-fangs. With these the spider seizes, holds, and kills his prey, by means of the poison, which he has secreted in a gland in the cephalo-thorax, and is able to pour into the wound he makes with his fang from a little opening at the tip of it. The fang is moveable, hard, sharp, and, as you see, curved. When not in use, it folds into a little groove at the base. The mouth, just below the falces, has two lips and two jaws, and a pair of long thin tubes, called palpi, on the jaws. At the other end of the spider, at the extremity of the 
abdomen, are the spinnerets, with which the animal spins his web. The number and shape of these spinnerets vary in different genera; there may be two, three, or four pairs; sometimes they are equal in length, sometimes the upper pair is much the longest, sometimes they are all short, and grouped together into a sort of boss. From these spinnerets, which are furnished with minute tubes, the spider emits a viscid fluid, which, on being exposed to the air, becomes hardened. This is the silk, or thread, with which the web is spun. Now, to us, this thread, so fine as to be almost invisible, appears single; nevertheless, each thread we see is composed of at least four, or six, or eight threads, according to the number of the spinnerets, and woven into one fairy-like cable as it leaves the spinnerets. I'll tell you more about the way in which the web is made another day. Do you understand this much?'

'Yes, quite, I think. Why, I believe I shall actually end in liking cobwebs as well as spiders; in time, you know; not just yet, perhaps. I should like to know what the inside of a spider is like, please; I always like to look at the insides of things.'

'Watches, and clocks, and bellows, and such like things, for instance. What a delightful person you must be to live with!' said Mr. Mygale.

'I am afraid I am rather troublesome; at least I have been when I was very young indeed, much younger than I am now. Insides have got me into 
no end of rows; but there is no harm in looking at the inside of a spider, of a dead one at any rate, is there?'

'None whatever ; but we should require my microscope, and there is not light enough for that to-day; but I'll show you some diagrams which will do as well. See, here is a diagram of a spider's heart and arteries. If you knew what cruel, relentless creatures spiders are, you would not believe they had a heart; but they have. See, it is a long, cylindrical organ, not the shape of a heart at all, placed in the upper part of the abdomen, and it pumps the blood into the aorta or principal artery, just as our heart does; this aorta runs through the little stalk which connects the cephalo-thorax and abdomen, and is then divided into arteries which supply the whole body. The blood is not red like ours, but colourless; and the fact that the spider has a system of arteries and veins shows it is higher in the scale of creation than insects, who have no true system either of circulation or of respiration; spiders have both, for they are provided with a pair of true gills for breathing, as well as with veins and arteries. They also have a gullet, a stomach, a liver, and an alimentary canal; and though they have no brain they have a nervous system like that of insects, and pale fibrous muscles, which are attached to the shell or outer skin.'

'Have they any ears? You forgot to teli me that.' 
'If they have, it remains for you to discover them. No one has at present done so; but it is a wellknown fact that they like music; many naturalists have observed this; their senses of touch and of sight are very highly developed; but we know nothing about their organs of smell and taste. Now just tell me the differences between spiders and insects; I want to see if you have been an intelligent listener.'

'Let me see-spiders' bodies are in two pieces, insects in three; spiders have eight legs, insects never more than six; spiders have no antennæ, insects have; spiders' bodies are never divided into rings, insects are; and spiders have no wings, and have simple eyes.'

'Quite right; and now what is your opinion of spiders? Do you like them?'

'I think they are very wonderful things; but I am afraid I don't quite like them yet,' said the child, in a deprecating tone.

' Not like them! boy, their cleverness is marvellous ; they are as cruel as even a boy could wish, unrelenting, crafty, fierce, venomous, persevering, industrious, with their snares and their webs, their nests and their nets, their traps and their wonderful trap-doors, to say nothing of their tents and their beautiful cocoons, and their devotion to their young; and you actually dare to tell me you don't like them!' said Mr. Mygale, in a tone of mock ferocity. 
But the boy was not alarmed; he sidled up to his host, and leaning his golden head against his shoulder, said in a gentle voice: 'I like you very much, and if you will be so kind as to let me, I should like to come and see you very often.'

'Come and see me very often, indeed! Why, you are my prisoner; you don't suppose I am going to let you escape out of my toils, do you? "Trespassers will be prosecuted,"-you are a trespasser, therefore you must be prosecuted; or, to save the bother and trouble to me, and the disgrace to you, of hauling you up before a magistrate, I'll try your case myself-I am a J. P.-and I sentence you to imprisonment in my house during my pleasure;' and Mr. Mygale looked as fierce and as ugly as he could manage to look.

'Well, I should like to be your prisoner very much, only there is mother: I don't quite see how to manage it,' said the boy, thoughtfully.

'What about your mother? What has she to do with it?' demanded M.r. Mygale; but the boy was lost in thought, and was silent for a minute or two; suddenly he exclaimed: 'I know what we can do; you let me go home and tell mother. I'll give you my word of honour I'll come back. Let me out on "parole," you know, like soldiers; I could not possibly break it, so mother will be forced, you see, to let me come. There is no help for her. The only thing is, I should like to know how long I am to be 
imprisoned, because my holidays only last five weeks, and this is the first day of them.'

'How many children has your mother?' demanded Mr. Mygale.

'Five: but I am the eldest; and now father is in India I am a good deal with mother-I take care of her.'

'Oh, indeed! well, the other four children can take care of her for the present. You tell her your imprisonment is to last one month; you won't be starved, you can have as much bread and water as you like, and your cell is next door to my bedroom. How far off do you live?'

'About half-a-mile. We have taken the rectory, because Mr. Smith can't afford to live in it, and we are going to live there very quietly till father comes back from India; he is only a poor captain, with nothing but his pay; but grandad is well off, and he pays the rent for us.'

'And pray what is your name, and when am I to expect you back? I can't give you a long parole.'

'My name is Claude Meadows, and it'll take me twenty minutes to run home and back, and about ten minutes to persuade mother, and there are my things to pack; nurse will take a dreadful long time over them, and then there are the little ones to say good-bye to, and the rabbits to look at; I am afraid I shall be gone a whole hour, but I won't be a minute longer.' 
"Very well, Mr. Claude Meadows, under the circumstances I release you on "parole" for one hour. Would you like to go out the way you came in, or by the side-door? The front-door is never opened.'

'By the way I came in, please; but I shall come to the side-door when I come back, because some one will have to come with me to carry my luggage.'

Accordingly, Mr. Mygale allowed his prisoner to escape by the trap-door, and as soon as he was gone rung for his housekeeper.

'Martin, put a small bedstead into my dressingroom, and bundle all my things out of there into my bedroom; there is a boy coming to stay here; and be sure to have plenty of jam-tarts, and sweets, and creams for dinner while he is here, and plum-cakes for tea, and-and everything boys like for every meal. You know better than I what to have; you can spend double our usual sum for housekeeping.'

'John Martin, John Martin, your master is as mad as a hatter! All I hope is he won't murder us and that child that is coming in our beds. It is that young master up at the rectory, that James, at the lodge, talks so much about, who is coming, I guess,' said Mrs. Martin, on returning to her own domain.

But Mr. Mygale spent the next hour in watching the clock, pacing his den impatiently, listening 
anxiously for every sound, and, as the hour grew to a close, inwardly abusing himself for his folly in dreaming that the boy would be allowed to keep his 'parole,' though he was firmly convinced it would not be the child's fault, if he were unable to do so. 


\section{CHAPTER II.}

THE RETURN OF THE PRISONER.

'The snare is laid for him in the ground, and a trap for him in the way.'-Job xviii. Io.

你 Claude Meadows left Mr. Mygale's den 'on parole,' and before the clock on the chimney-piece chimed half-past five there was a violent ring at the side-door, followed, as soon as it was opened, by the boy's voice giving some directions about his luggage in the hall; then a scamper towards the study, the door of which was burst suddenly open, and Claude, with his cheeks flushed, his blue eyes sparkling with glee, rushed in, seized hold of one of Mr. Mygale's hands, and exclaimed, panting, 'Here I am! I ran the whole way; mother didn't very much like it at first, but she said it was quite impossible for a soldier's son to break his parole; father would never forgive me if I did such a thing, so she let me come. That was a capital dodge of mine, going out "on parole," wasn't it?' and 
the boy pealed out another of his laughs, which were music indeed to his host's ears. But almost before Mr. Mygale had time to answer the merry face grew grave, and a tender, thoughtful look came into the blue eyes as their owner looked into the fire, and said, half-aloud:-

'I hope she won't be very lonely without me. She need not be afraid of me breaking my promise, and she won't, that's a comfort.'

'What promise?' said Mr. Mygale, who was watching his little guest, and inwardly hoping the boy was not going to have an attack of home-sickness.

'I can't tell you all the promise; part of it is a secret; the other part was, I promised to be as good as I could be, without mother;' and the red lips trembled slightly, and something very like tears rose to the blue eyes.

' Oh! and if you were to break your promise, what then?'

'I should be dreadfully sorry, and I think you'd have to let me out "on parole" again, to go home and tell her. But I don't mean to break it if I can help it ; I mean to keep it all, the secret part as well,' said the child, rallying.

'That is a very creditable sentiment, and I hope for my sake, as well as your mother's, you will keep the part of your promise you have confided to me.'

'The secret part concerns you the most, though 
but we must not talk about that. What time shall I have to go to bed here?'

'When you like. I'll tell you what my hours are: I have breakfast at nine, luncheon at one, tea at five ; it is later to-night, because I waited for you-here it comes; and dinner at half-past seven. Will that suit you? You can go to bed as soon after dinner as you like.'

'Half-past eight is generally my bed-time, but mother said you would settle all that. I suppose I shall be allowed to come in to dessert after dinner?'

'You'll have to dine late while you are here; you'll have to eat two dinners a day, one at one, and another in the evening; bread and water for both. It is part of your sentence; come and get your tea now.'

'Dine late every night! Oh! I shall like that; it will be nice staying here; now, I'll tell you what I should like to do, as soon as we have had tea;-may I pour it out? I always make her afternoon tea ;' this with a little sigh for her.

'You may; and pray what do you wish to do?'

'Go all over this house, into every room; and I should like a game at hide-and-seek, but I am afraid that is impossible; I am afraid you couldn't manage it, could you? And I suppose Martin will be busy laying the cloth, and Mrs. Martin cooking the dinner?'

'You have divined Martin's and his wife's occupa- 
tions with great accuracy. But I shall have much pleasure in showing you my housc, even if my intellect is not equal to grasping the mysteries of hideand-seek.'

' Oh! you are clever enough to do it; I was afraid you were too old to care for games; I don't play them every day myself, but I don't want to think about her too much to-night.'

'I see; well, you shall go over the house first, and then teach me hide-and-seek.'

Accordingly, the next two hours, until the dressingbell rung, were spent in exploring the house, the corridors of which echoed with boyish laughter and shouts of 'whoop,' now from Claude, now from Mr. Mygale, to the infinite amusement of Martin, and terror of his wife, who was more certain than ever of her master's insanity. The dressing-bell found them both hot, dusty, dirty, and dishevelled; but one of them, at least, was happier than he had been for many a day, for his loneliness had been abruptly broken into, like a gleam of sunshine across a barren moor; the boy's youth, and grace, and beauty shone upon the old man's life, and, in trying to give pleasure to his little new-found friend, Mr. Mygale himself experienced happiness hitherto unknown to him. In spite of this, however, he could not resist the temptation to tease the child, for Mr. Mygale was nothing, if not a tease; so, when they sat down to dinner, Claude radiant in his black velvet suit, a tureen of soup was 
put before Mr. Mygale, and a large piece of stale bread, on a silver plate, and a glass of cold water, to his guest.

To Mr. Mygale's astonishment, the child paused a moment, as if waiting for something which did not come, and then, bending his golden head before he sat down, said his grace to himself, and began upon the stale bread as if it were his usual fare.

'I an so hungry!-but, I say, how pretty the table looks. What lovely flowers you have! and I do like silver dishes and plates; they must take Martin a long time to clean, though, that is the worst of plate.'

'Don't you wish for some soup?' said Mr. Mygale.

'I don't mind the dry bread, I am so hungry after that game; you said I might have plenty of it, and I always drink water.'

'Take that bread away, Martin. Give Master Meadows some soup directly. I was only teasing you, child; did you really think I meant to eat a big dinner while you munched a dry crust?' he added, while Martin went to fetch the fish.

'Well, I thought you might keep me on bread and water for a day or two, perhaps, but I didn't think you meant to do it all the time I am here.'

'Oh!' grunted Mr. Mygale. 'And pray may I enquire how you propose to spend the term of your imprisonment?'

'Well, I think in the mornings you might teach 
me all you know about spiders; then, in the afternoons, we'll go out; in the evenings we'll play games, as we did to-night. It need not always be hide-andseek, because, perhaps, you would like a quieter game, backgammon or chess. I don't know either, but of course you do; and after dinner I am afraid I shall be getting sleepy.'

'I sincerely hope so, for you have not left me much margin for reading or writing. My work seems to be cut out for me,' said Mr. Mygale, grimly.

After dinner, Claude made one or two efforts at conversation, but he was so sleepy he was obliged to go to bed; so, rising from his seat, he went round to Mr. Mygale's chair, and said,-

'I am afraid I can't stay up to prayers, I am so tired: may I go to bed?'

'By all means; there are no prayers to stay up to.'

'Well, I think there ought to be in a big house like this. Why don't you have them?'

'Er-really-ahem! suppose we discuss that interesting question another day, when you are less sleepy. Good night! Ring for Martin if you want anything.' And Mr. Mygale held out his hand, but, to his surprise and inward delight, the boy bent over him and kissed his forehead.

The next morning, to Mr. Mygale's relief, Claude was so full of beginning his lessons on spiders that he forgot to renew the subject of family prayers.

'Now,' began Mr. Mygale, when Claude had seated 
himself in a most business-like way at a table, "the first thing you must do is to make out a table of the different families of spiders, then I'll describe each family or genus, if I have time, to you separately. It will be rather dry at first, and you'll have to learn some hard names ; but you have begun Latin, I suppose.'

'I know my declensions pretty well,' said Claude.

'That is all right; then you won't mind the Latin names. Now take a sheet of paper, and while I explain it to you copy this table of British spiders. As I told you yesterday, spiders are divided, according to the number of their eyes, into three tribes; the tribes are again divided into families, the families into genera, and the genera into species. The first tribe has eight eyes, and is called Octonoculina, eight-eyed. This contains ten families, five of which are hunting spiders, the other five catch their prey in snares which they weave; nine of these families have six spinnerets; the tenth family, the Ciniflonida, has only four. The second tribe has six eyes, and is called Senoculina, or six-eyed. It contains only two families. The third tribe has only two eyes, and is called Binoculina, or two-eyed. But with this tribe I won't trouble you; because, though I will tell you all I know of foreign spiders, our actual study had, I think, better be confined to the British spiders.'

'But I should like to know all about those monsters you have in that case up there: they are not British, are they? 
'No, I am glad to say they are not: they are Mygales; we have only one British representative of that family. I'll show you some of them this morning, if there is time, after you have made out the list of the families and genera.'

This was rather a lengthy process, for Claude wrote slowly, and Mr. Mygale was particular to have the table neatly written and arranged. When completed it stood thus :-

TRIBE I.

Octonoculina or Eight-eyed.

FAMILY I.

Mygalide or Trap-door Spiders.

Genus. Atypus or ill-shaped.

FAMily II.

Lycosidce or Wolf-spiders.

Genus I. Lycosa or wolf.

- II. Dolomedes or strategist.

— III. Heccërge or distant action.

- IV. Sphasus or butcher.

FAMILY III.

Salticida or Leapers.

Genus I. Eresus or fixers.

- II. Salticus or leapers.

Family IV.

Thomisida or Binders.

Genus I. Thomisus or binders.

- II. Philodromus or lovers of running.

- III. Sparassus or tearers.

Family V.

Drassida or Seizers. 
Genus I. Drassus or seizers.

II. Clubiona.

III. Argyroneta or silver spinners.

These are all hunting spiders.

$$
\text { Family VI. }
$$

Ciniflonida or Hair-curlers.

Genus I. Ciniflo or hair-curlers.

- II. Ergatis or workwomen.

- III. Veledta or soldiers.

\section{FAMILY VII.}

Agelenida or Foragers.

Genus I. Agelena or foragers.

II. Tegenaria or roof-raisers.

III. Calotes or hollow.

IV. Textrix or spinsters.

FAMILY VIII.

Theridizdc.

Genus I. Theridion.

_ II. Pholcus or squinters.

$$
\text { FAMILY IX. }
$$

Linyphiide or Weavers.

Genus I. Linyphia or weavers.

II. Neriëne, from neuris, a thread.

— III. Walckenaëra, from Walckenaër, a naturalist.

- IV. Pachygnatha or thick-jawed

$$
\text { FAMILY X. }
$$

Epëirida or Geometrical Spiders.

Genus I. Epëira or Geometrical spider.

- II. Tetragnatha or four-jawed.

TRIBE II.

Senoculina or Six-eyed.

FAMILY I.

Dy'sderidet. 
Genus I. Dysdera or difficult combat.

- II. Segestria, from segestre, a mat.

_- III. Oonops, or egg-shaped eyes.

\section{FAMILY II.}

\section{Scytodidle.}

Genus. Scytodes, from scutos, a kind of shield.

'Are you tired? Have you had enough of arachnology for this morning?' said Mr. Mygale, as Claude finished the table.

'I am, rather-at least, my hand aches. But what a funny word arachnology is. What does it mean?'

'It means the science of spiders, from two Greek words-arachne, a spider, and logos, a word or science. But, as you are tired, we will stop for this morning. It is just twelve o'clock, and I see your friend the lodge-keeper coming up to be tried and sentenced for his share in your crime.'

'Oh! you won't punish him, will you? You see, it was all my fault, not his at all; and you are giving me a lovely treat instead of a punishment, so it would not be fair not to let him off too.'

'Let him off, indeed! There is a very bad quarterof-an-hour in store for him, I can tell him. Well, James, and pray what have you to say for yourself for daring to disobey my orders in this way? Haven't I told you, over and over again, I strictly forbid you to allow any one, man, woman, or child, inside the park gates, on any pretext whatever, except by my express permission?" 
'You have, sir,' said the lodge-keeper, who stood just inside the study, fidgeting first on one leg, then on the other, and turning his hat round in his hand, looking very nervous and ill-at-ease.

'And yet you admitted this child yesterday afternoon, in direct opposition to my orders?' demanded Mr. Mygale fiercely.

'Well-yes, sir, I can't deny it. I did do so, and I ask your pardon; and I humbly hope, sir, that, as it is a first offence, you'll be so good as to overlook it.'

'Overlook it, indeed!' interrupted Mr. Mygale. 'Why, I have sentenced the child to a month's imprisonment; you don't suppose you are to go scotfree, do you?'

'Pray, sir, don't turn me away, for my poor wife's sake. We hadn't the heart to refuse the young gentleman, when he said so prettily, "I don't think your master would mind me, and if he does, I'll take the blame." "

'So he has, and the punishment too; so for this once I'll forgive your offence; but take care it does not occur again, or you won't get off so easily. You can go,' said Mr. Mygale curtly.

James required no second dismissal. Murmuring his thanks, he beat a hasty retreat, congratulating himself on the unexpected leniency he had met with at his eccentric master's hands.

The rest of the day was spent as Claude had planned; but he gave his host to understand that, 
although he was content to keep inside the parkgates that afternoon, he would not rest unless $\mathrm{Mr}$. Mygale consented to go beyond his own grounds the next day.

'It'll be Sunday, though; so of course we shall go to church,' said Claude.

'You may, if you like; I never go to church,' said Mr. Mygale abruptly.

They were going across the park towards the house as he spoke, and for a few minutes afterwards they proceeded in silence. Presently a small hand was thrust into one of Mr. Mygale's, and looking down he saw the boy's face wore a sorrowful, disappointed expression.

'What is the matter?'

'I am sorry you can't go to church with me tomorrow, because God will be angry with you. I wish you would come with me some Sunday, even if you can't possibly manage it to-morrow. Will you, please?' and the blue eyes looked wistfully up into the wrinkled face.

'We'll see. I won't promise, but I'll think it over while you are there to-morrow.'

'Oh, thank you! I am glad! I think I shall be able to keep my promise to mother.'

This last remark was made in an undertone, and was evidently not intended for his companion's ears; so Mr. Mygale pretended not to hear it, notwithstanding the fact that he felt intensely curious to 
know what this promise, to which Claude had once before alluded, could be.

And on Sunday the great square Hall pew, which had been empty from time immemorial, was occupied by a boy, whose behaviour during the service was most exemplary, but whose human nature was overcome by sleep during the sermon, when his innocent spirit wandered into dreamland.

'Well,' said Mr. Mygale, who was anxiously looking forward to the boy's return, as the child came in radiant; 'so you have come back. I half expected you would go home with your mother and leave me.'

'No, I like being here, and she is getting on as well as she could without me; the children are all very good, and she is so glad I am happy, and hopes I don't tease you. I said, No; it was you who tried to tease me, only you can't.'

'Oh, can't I? I am afraid you don't know the extent of my teasing powers yet. Suppose we have a lesson on spiders before luncheon.'

Claude coloured; then burst out laughing.

'You are trying again; you know I don't wish to learn about spiders on Sunday. I want you to read to me, please, and hear me say a hymn I have been learning; then we'll do the spiders directly after breakfast to-morrow.'

So Mr. Mygale found himself reading the Pilgrim's Progress, and listening to words that brought back his young childhood, lisped out by those childish lips. 
He found, too, that children are wonderful teachers, all unconscious as they are of the fact. Long-closed doors in his memory were opened, and associations of his early life were stirred as Claude repeated-

'There is a fountain filled with blood,

Drawn from Immanuel's veins;

And sinners plunged beneath that flood,

Lose all their guilty stains.

The dying thief rejoiced to see

That fountain in his day;

And there may I, though vile as he,

Wash all my guilt away.' .

On Monday morning Claude was as anxious as any arachnologist could desire to resume the study of spiders; and no sooner was breakfast over than he dragged Mr. Mygale into his den, and begged him to tell him something about a large spider, almost as big as a spider-crab, of which he had several specimens.

'Luckily for you, that spider is a Mygale, and belongs to the first family of the Eight-eyed tribe, or I should not gratify your curiosity by beginning with it; because I mean to take the families straight through, then there will be a little method in our madness. The Mygalide, or Tunnel spider, is a family represented in England by one genus only; indeed, by one species, Atypus Sulzeri. I have a specimen of the spider in that case over there, and several of its nest. Here is one, a tube, lined, as you see, with white silk, spun, of course, by the spider; this tube is always made in damp earth, first of all in a horizontal direction, like 
a gallery; afterwards, it descends into the earth, and at the end of it crouches Lady Atypus. I found this particular nest in a high sandy bank, where the end, hanging down like the cocoon of a moth, attracted my attention. It is nine inches long, and some are still longer; others shorter, for they vary in length. At the bottom of the tube was the spider, Lady Atypus, who, by the way, is a very Xantippe among spiders, being larger and stronger than her husband, and having a propensity to eat all other gentlemen of her species. Atypus himself declines to live with her; so they keep separate establishments, the wife living in her tunnel, but the house of her husband is veiled in mystery; all I know is, no males are ever found in the tunnels. Another point which puzzled naturalists for a long time is, on what does Lady Atypus live? For we never find any remnants of flies or any other insects in her tube.'

'Perhaps, as she is fierce and eats all the gentlemen she knows, she eats every scrap of a fly; or perhaps she goes out at night and feeds.'

"That is much more probable; there is only one objection. There is no door to her tube at either end; but it is possible she closes it up by day, and opens it at night. The end which hangs down outside the earth is two inches long. Now you see my specimens are flabby, flat-looking things; but the spider has the power of inflating her tube at her pleasure; but how she does this is more than I can 
tell you. Inside the tube, the silk is beautifully white and clean; but outside it looks soiled, because it is covered with grains of sand. It is possible you may be right about her eating up every scrap of her prey; for it is known that she remains with her feet on the end of her tube, so that if the tiniest insect passed over the sac which hangs outside the earth, she would feel it, and probably dart out and devour it. This, as I said before, is the only British representative of the Mygalide. In the Riviera, near Cannes and Nice, there is a species called the mason-spider, or Mygale camentaria, because it makes its tube of clay; and a beautiful piece of work this tube is. No human mason or potter could equal it; it is lined with the finest silk; but its most remarkable feature is the lid, in shape like a button, attached to the tube by a hinge, and bevelled at the edges, so as to fit perfectly to the tube; this remarkable lid is lined with layers of silk, and ventilated, actually ventilated, by these little holes you see perforating the lining in a circle. The outside of the lid is made of clay, and is hard and smooth, and so exactly the colour of the ground that it is most difficult to find one of these nests.'

\section{'As hard as it is to discover your trap-door ?'}

'Harder, probably; for although I took the pattern of my trap-door from the Mediterranean Mygale, it falls far short of the model. See how beautifully the lid tapers inside, and how firmly the silk is attached 
to the clay; to this silk the spider, if disturbed by any enemy,-a bird for example, which tries with its claws to open the trap-door and seize Mygale with its beak, - - hangs on by its pincers, and fixes the little hooks with which its claws are furnished into the sides of the tube, and holds on like grim death.'

'It would be grim death if it let go, wouldn't it?' said Claude.

'It would for the spider. Another point I want you to notice in the trap-door is, it is thinnest near the hinge and thickest at the opposite edge, so that its own weight suffices to keep it shut. But the Jamaica trap-door spider, Mygale nidulans, is the cleverest of all in the arrangement of its tunnel; there are two tubes, the outer thick, brown, and resembling bark; the inner, smooth, white, and like rough stiff white paper: if you were to put this inner tube into a microscope, you would see it is made of coarse silken threads,-coarse I mean for a spider,-twisted into little heaps and stiffened with gum. The door is round, and made of the same substance as the tube; the inside white, like the lining of the tunnel; the outside is covered with earth, and the lid fits so truly that it is almost impossible to discover it; the hinge is a widish one, and is always on the upper side of the hole, which is made in sloping ground, so that when the spider goes out his door closes after him and completely hides his tunnel, thus securing his home from burglars during his absence. If any enemy succeeds in dis- 
covering the trap-door when the spider is at home, he dashes up to it, hooks his hind-claws to the lid and his fore-claws to the side of the tunnel and holds on with all his force. Very often the spider may be seen peering out of its hole with the lid slightly open, and if startled, it darts back, slamming its door sharply. I was once sharp enough to catch one, though; there he is in that case; you know him well enough.'

'Yes, but I want to look at him again, please; he is very much like a crab, isn't he?'

'Yes, the French call him the Crab-spider, and he is as big as a small crab; his body measures an inch and a-half without his legs; they are short, but very strong; and his fangs are very alarming, just look at them and notice they are jointed horizontally; the feet are furnished with hairs, to enable them to walk up perpendicular or very smooth surfaces. Mygale nidulans is nocturnal in his habits; he goes out hunting at night, and sometimes, I expect, brings home some large beetles, for remnants of them, and of all sorts of insects, are found in his den. It is said that he sometimes catches humming-birds and other small tropical birds, but I cannot vouch for the truth of that statement; if he can catch them in his webs, he is certainly strong enough to kill them after he has caught them, but I don't believe the report.'

'Are there any other Trap-door spiders besides the English one, and the French one, and the Jamaica one?'

' Oh yes, they are found in many parts of the world; 
there is an Australian species which makes a marvellous nest; I have not a specimen, but if ever you go to London you can see one at the Natural History Museum in Kensington, and if a human potter had made it he could not have turned a neater piece of workmanship on his wheel; the edge of the tube as well as of the lid is bevelled, so that the door closes quite accurately. The hinge is a piece of the silken tube which lines the tunnel, and the lid is thinnest near the hinge, so that its own weight closes it; the outside of the lid is made rough, to resemble the ground in which the tube is placed. Here is another species, which I found in Greece, Mygale Ionica. The nest was at the root of an olive tree: there were two others close by, one I gave away and one I left, this is the third; they were in clay soil, and all about the same length, four or five inches. But there is a remarkable peculiarity about the door I want you to notice. Do you see how the edge of the lid projects just above the hinge? Now that projection acts as a lever to open the door from the outside; the least pressure on it opens the door; and a wonderfully clever thing it is too: fancy a spider understanding one of the great mechanical powers! Oh, boy, spiders are marvellous creatures!'

'I don't think the inside of this Greek spider's nest is so well finished off as the other nests we have been looking at.'

'You are quite right, it isn't; the fact is, Ionica is 
more of an architect than of a decorator. He has been paying so much attention to the leverage of his door, that he has had no time for papering his walls or hanging them with silken curtains. Now here is an African spider, Actinopus adificatorius (or Actinopus, the builder) is his name, and he is as black as a Negro; blacker, in point of fact, and shines like a well-polished
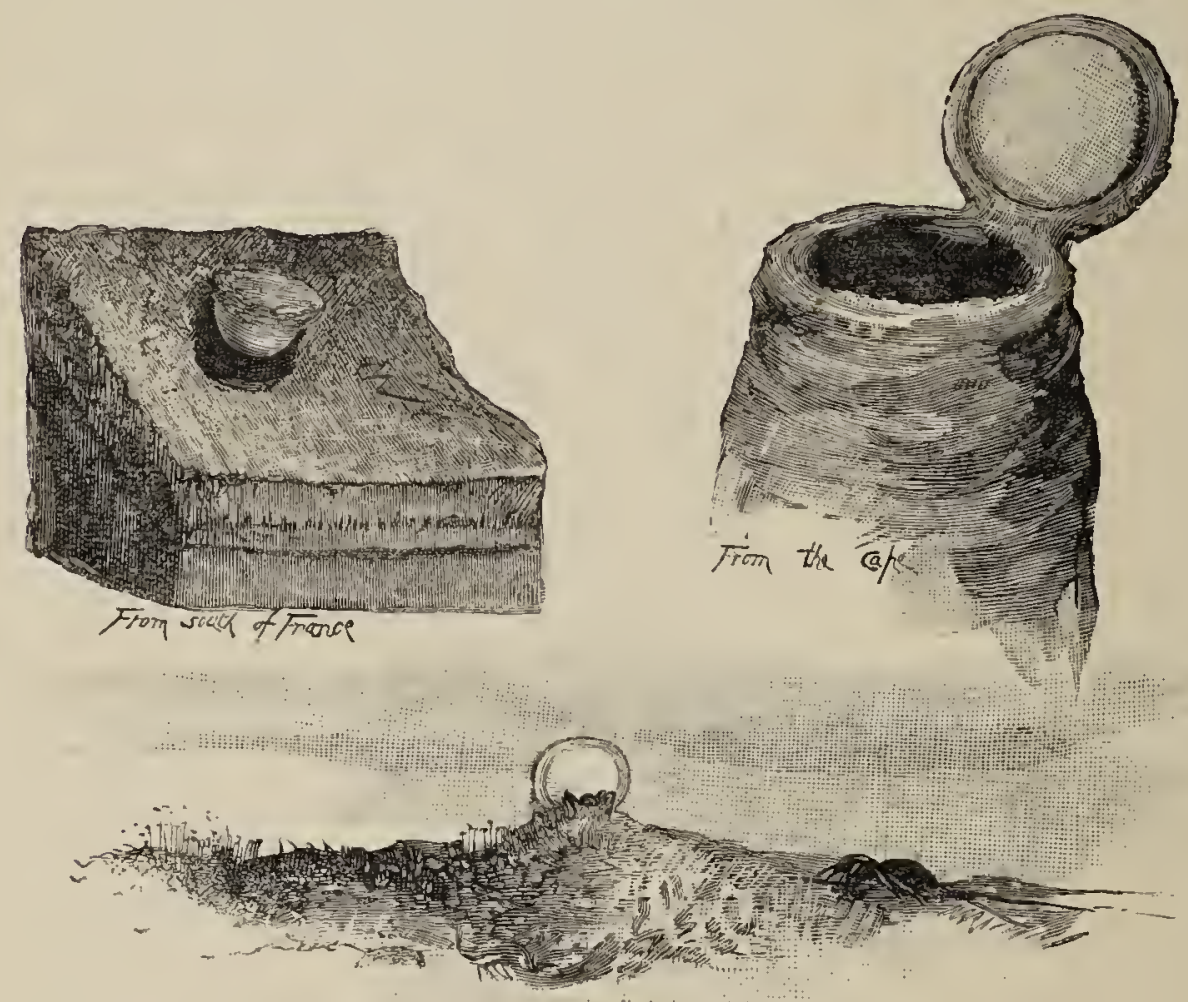

NEST.

grate. The legs are covered with hair and fine bristles, and are ncarly all the same length, though they vary in thickness; the palpi are as long as the legs. The nest is about an inch in diameter and four inches long; the mouth and the lid which covers it are oval, and both bevelled off at the edge. This nest, as you see, is most beautifully lined with pure white silk; the lid is made of layers of coarse silk, with which, on the out- 
side, pieces of earth are intermingled, to make the door look like the ground in which it is placed.'

'It looks like a baby oyster-shell,' said Claude.

'It does; and now, I think, we have had enough of spiders for to-day; there is the gong for luncheon; to-morrow we will spend with the wolves.'

'The rvolves! Oh! I see what you mean; you need not try to look so terrible; there are wolf-spiders, I guess. But, please, I want to ask you a question; you won't mind, will you?'

'I can't say till I know what it is.'

'Well, I have been thinking Mygale is a very funny name for a person; it is a spider's name, not a gentleman's ; now, I want to know, is it your real name?'

Mr. Mygale started as if he had been shot, and then said sharply, 'It strikes me you want to know a great deal too much; don't you know it is very rude to ask personal questions?'

'I beg your pardon, I didn't mean to be rude; only, you see, it is so very funny your name should be the same as a spider's; I could not help asking,' said Claude, slipping his hand into his host's, as they went towards the dining-room.

'Never mind, you were not rude, only don't tell anybody else that Mygale is the name of a spider. See if you can keep that secret, and, perhaps, I may tell you a more important one some day. You never heard any one else say Mygale was a funny name, I suppose, did you?' 
'No; I didn't think it funny myself, till I knew it was the name of the Trap-door spider.'

'Ah! I see; well, don't mention it before Martin.'

Claude remembered this caution; but, nevertheless, he was destined to make a second mistake that day, for at dinner, after a somewhat long pause, he suddenly asked :-

'Why is this place called Sutton Park when the village is called Bridgenorth?'

'Because the original owners of the place were Suttons; until I came to live here, twenty years ago, no one but a Sutton had lived in it since the house was built, in the fifteenth century.'

'Then do you hire it of the Suttons?'

'No, it is mine; there are no Suttons to hire it of, the late baronet died abroad, and left no children, and the next of kin sold the place to me.'

'Well, if I were you, I should call it Mygale Park, as it has nothing to do with the Suttons.'

'Should you? Are there any other improvements you would like to suggest?'

'Yes, a great many. If I were rich like you, I should keep plenty of servants-not too many, you know, but enough for a big house like this-and some horses, and a carriage or two; and I should open all the shutters, and have fires in all the rooms, and have all my friends to come and stay with me, because it is so dull all alone.'

'But I have no friends, you see.' 
'Yes, you have; you have me, and Martin, and Mrs. Martin; she is awfully fond of you, I know, because she told me so, if only you were not quite so particular about the cobwebs.'

'You have accurately summed up my friends; so, you see, there is no occasion for me to open the rest of the house to accommodate you and me and the Martins. But, if you like, we'll have the big diningroom and the best drawing-room opened next Sunday. Tell Mrs. Martin to have fires in both, and we'll dine in the dining-hall, Martin. You can ask James and his wife up from the lodge to help, and to dine with you in the kitchen, or the servants' hall, if you like, afterwards.'

'Oh, thank you, that will be fun; what a happy day I shall have, if--if only-' and the bright, happy face grew grave.

'If only what?' demanded Mr. Mygale.

Claude glanced at Martin, and with an elaborate attempt at a wink signified that he could not answer this question till they were alone.

Mr. Mygale was curious on the subject, so, as soon as Martin had left them to their dessert, he repeated his question.

'I was going to say, I should be quite happy if only you would take me to church in the morning.'

'Is that all? I wish every one were as easily made happy. Well, I'll take you.' 


\section{CHAPTER III.}

A PRACTICAL JOKE.

'Which doeth great things past finding out, and wonders without number.'-Job ix. Io.

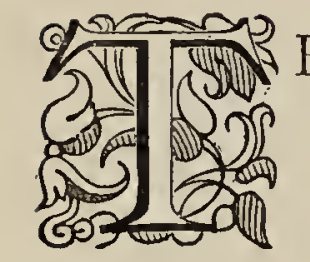

HAT Sunday at Sutton Park was a redletter day in its annals. For twenty long years the day had been passed over as any other day; but on this occasion Mrs. Martin gave it as her firm opinion that the world must be coming to an end, and that very speedily; since the best rooms were opened, dinner was served in the old dining-hall, which had not been used since she had known the house, and, wonder of wonders, Mr. Mygale went to church.

'This has been a happy day, hasn't it?' said Claude.

'I can't say I have ever found it so before; but, now you mention it, I believe I have been happy to-day,' said Mr. Mygale.

- That is because you have made such a lot of other people happy - the Martins, and James and his 
wife, and me; and Mr. Smith, he looked so happy when he saw us come into church. Mother is quite right, isn't she? She says the way to be happy yourself is to try and make other people happy, and the more you succeed in that the happier you'll be. I suppose that is one of the reasons Christmas is such a nice time, because every one tries to make every one else enjoy it. Please will you tell me what does that red hand mean on that screen? I have seen several of those hands about in this house. Is it your crest, or the Suttons'?'

'Neither; it is the sign of the baronetage. Every baronet is allowed to bear a blood-red hand on his coat-of-arms. It belongs to the Sutton family, and I have left everything just as I found it in all the rooms, except those I occupy.'

'I see; but I think, if I were you, I should have those hands taken away, as you are not a baronet. You don't mind me saying so, do you ?'

'Not in the least, particularly as I do not intend to adopt the suggestion. Next to my spiders and cobwebs, I like those blood-red hands the best of all my possessions.'

Claude longed to say, 'But they are not yours really,' only he feared it would be rude, so he restrained the inclination, guessing with instinctive tact that such a remark would be most unwelcome to his host.

'Now for the wolves,' said Mr. Mygale the next morning, when Claude came for his lesson. 'But 
before I begin on them, I want to know if you have any idea of how spiders produce their young?'

'They lay eggs, don't they?'

'Right; the eggs are enclosed in a cocoon, the shape, colour, and situation of which vary much in the different genera. The cocoon is made of silk, but the silk of the cocoon is eighteen times as coarse as that of which the web is made; and you may gather a faint notion of how fine the spider's websilk is when I tell you the silk of a silk-worm is five times as thick as the cocoon silk of a spider. Spiders' silk is too fine for manufacture, though I believe several attempts have been made to utilise it. There is a spider in Paraguay which makes a beautiful yellow cocoon, and this silk is sometimes used for spinning by the natives, because of the durability of the colour. But I don't suppose spiders' silk will ever be used. The cocoon silk only would be strong enough, and that is only spun by female spiders. Moreover, the number of spiders required to spin a pound of silk is twelve times as great as the number of silkworms required for the same. But I was going to tell you that the British tunnel-spider, Atypus Sulzeri, makes a single white cocoon, about half-aninch long, and places it on a cushion, made of her own silk and fibres of leaves, to protect it from damp. If ever you catch an Atypus, you will find it will feign death.'

How many eggs are there in a cocoon?' 
'It varies; sometimes only five or six, sometimes a great number. A female spider is generally said to lay about a thousand 'eggs in a season, and inside each egg the young spider is found, enclosed in a tiny sac. It does not leave this sac immediately the egg is hatched, and remains in the cocoon till it casts the sac. Now I dare say you will be surprised to hear that spiders are excellent mothers. Many of them carry their cocoons about with them until the eggs are hatched, and will defend them with their own lives. If the cocoon is accidentally separated from them, they immediately spin some more threads, to fasten it on to their bodies again; and after the young brood leaves the cocoon-which, by the way, they cannot do till the mother bites a hole in it - then she takes them up on her own back and carries them about until they are old enongh to spin webs for themselves. This they begin to do almost before they are visible to the naked eye.

'But now to the wolves. The spiders of the family Ly'cosida are generally found either running about the ground in search of prey, or lurking under stones intent on the same object. The wolf-spiders properthat is, the genus Lycosa-have no home, and make no snares. They spend their lives in hunting for prey, except during the winter, when they either take refuge under stones or in holes in the ground. They are very fierce and eager, and very quick, darting about slaying one victim after another. Nevertheless, 
the mothers are very tender with their young. Having no home, they carry the cocoon about with them till the young are hatched, and then carry the young brood until they are a fortnight old. If the cocoon is attacked, the mother will defend it most bravely; and it is said that if deprived of it she hides herself and dies of grief. The cocoon is remarkable for being in two halves, which are united by a thin membrane, through which the young spiders make their way into the world. There are sixteen British species of Lycosa, the greater number of which are found on commons or heaths, or in fields or woods. Five species are more aquatic in their habits, and are found in marshy places, and on the edges of pools or ban'ss of rivers.'

'Are you going to tell me about every one of the sixteen wolf-spiders?'

'No; I should not have time for that. I propose telling you a little about the most remarkable species in each family, and then I'll make you out a table describing every British spider and its cocoon, which you shall take away with you when your imprisonment is over. Now one of the most remarkable Lycoside is a species called exigua. It is a common spider in fields and on heaths; but I mention it particularly because it is one of those spiders which appear to fly, but in reality are floating in the air on a web. As a rule, it is minute species which do this, but exigua is a quarter of an inch long.' 
'How does it manage to fly without wings?'

'Well, it does not actually fly. It first of all creeps up a tree or a wall till it is high enough to perform this aerial Blondin-like feat; then it turns its head to the wind, and begins to spin several fairylike silken threads. On these it travels, carried up by the wind, which bears both spider and web whither it will. Haven't you often noticed in the autumn fine gossamer threads floating about on the breeze? These are some of the threads spun by spiders who aspire to flight. But the most interesting of the wolves is, I think, Lycosa piratica, or the pirate-spider. It is furnished with a sort of diving apparatus. The abdomen is covered with hairs, which catch the air in such a way that the creature is enabled to dive, which it does directly it finds itself in danger. It lurks about near the waterside, and pursues its prey over the surface of the water. Another species, called piscatoria, or fisherman, is very like piratica in its habits.

'Now I think we may go on to the second genus, Dolomedes, the strategists. We have only three British species. They are very like the wolves in their habits. They have no home, but spend the night under stones or in a hole, or perhaps in a crumpled leaf. In bad weather they take shelter; but they spend their days in running about the ground, looking among the grass for prey. The female Dolomedes mirabilis carries her cocoon about with her, fastened on to 
her body with some silken threads, while she is hunting; but when the hatching-time draws near she retires to a tent, which she builds for herself, and there she stops till the young spiders are old enough to shift for themselves.'

'But how can a spider build a tent?'

'Bcautifully, very much better than you or I; she takes some grasses or tiny branches for the rafters of her roof, and then spins an awning of beautiful, fine, closely-woven silk over them. There is one, Dolomedes fumbriatus, found in the fens of Cambridgeshire, which is aquatic, and very like the pirate spider in its habits.

'Of the third genus, Hecaërge, we have only one species, spinimana. It is found in woods, and is very active. The mother fastens her cocoon to the under side of a stone, and is furnished with a brush below her claws. The genus Sphasus also has only one British species, called lineatus, I suppose because it is marked in lines. This spider has a habit of leaping on its prey, in which it resembles the Leapers; but in its other habits it is like Dolomedes. Are you tired now? shall we stop here?'

'Well, I want to ask you a question, please; it is not about spiders, it is about a Mygale, though.'

'Does that mean it is about me? I told you the other day I don't like your personal questions.'

'Yes, at least I think it is. I must ask it; every time you said one spider was like another, it reminded 
me of it. I want to know who that picture represents in the big dining-room, just over the door. It is very like you, only he must have been taller than you are; and I can't make out why it is like you, because Martin told me it was one of the Suttons, only there was a secret about him: is it true?'

'It is true that you and Martin have been gossiping about things that don't concern you. Another time, when you want to ask questions of that kind, come to me, not to Martin. Yes, it is true that it is the portrait of a Sutton. He was a brother of the late baronet, and there is a story about him which, perhaps, I may tell you some day; but as for the picture being like me, that is only a fancy of yours; or if there is any truth in it, it is a mere coincidence. I shan't teach you any more about spiders to-day; go and play in the park, you can go by the trapdoor, if you like.'

Claude did like, and disappeared with a lantern down the ladder, in high glee. No sooner had he gone, however, than a spirit of mischief entered into Mr. Mygale, and he determined to play a trick on the boy, and test his temper; so, securing the trapdoor in his den, he ran out of doors to the door on the grass, and listened till he heard a faint boy's whistle underground, then he went down on his hands and knees, and held the lid of his tunnel so firmly closed that all Claude's efforts at opening it were in vain. For nearly a quarter of an hour the child 
pushed and pushed, but with no success; then he was heard to say aloud, 'I must go and fetch Martin or Mr. Mygale,' and apparently back he ran to the other end of the tunnel.

Mr. Mygale leisurely retraced his steps to the house, chuckling greatly over his practical joke. When he reached his den, a furious knocking was going on under the trap-door, and Claude's voice was heard calling :-

'Mr. Mygale, I can't open either of the doors; let me out this way, please, Mr. Mygale.'

But Mr. Mygale paid no attention, only chuckled, and coughed, to let his victim know he could hear him.

'You are in the study, I know ; let me out, please. I can't open the other door. Mr. Mygale, I can hear you coughing: open the door, please. I don't like being in this tunnel with nothing to do. Will you open the door?'

A derisive laugh was the only response to this appeal, which had the effect of rousing the boy's temper; and he kicked and banged on the door with all his might; shouting out-

'How dare you keep me here all this time? I'll go home directly I get out, that I will. Let me out directly, you horrid old tease, you! Martin, Martin, come and let me out! it is a shame, teasing me like this. I will come out-I'll break your old door open! I hate you, that I do!' To all of which Mr. Mygale only answered by laughing till the tears ran down his cheeks. 
'The boy has some of the old Adam in him,' he muttered.

In the midst of Claude's knocks and shouts, the gong sounded for luncheon, and then Martin appeared to announce that it was served.

'Martin, Martin, that old wretch has locked me in here! Let me out. I have been here for hours, I am sure; open the door quick!' cried Claude.

'Let him out, Martin; he has been there about half an hour; I daresay he is hungry.'

'That he isn't; he is only angry. He'd like to half kill you, you old wretch!' exclaimed Claude, as with flaming cheeks and clenched fists he would have dashed at Mr. Mygale when Martin opened the door, if Martin had not caught him in time.

'Master Claude! you must not do that. It was only a joke you know, sir.'

'Let the boy alone, Martin; I can defend myself if I care to. Come, child, wash your hands and follow me to luncheon. As Martin says, it was only a joke.' And Mr. Mygale went into the small diningroom, followed by Martin.

But no Claude appeared. Martin was sent up to fetch him, but returned with the news that he was locked up in his bedroom, crying bitterly, and refused to admit Martin or Mrs. Martin, who was outside the door with patties and jam-tarts; but Claude turned a deaf ear to all her entreaties.

'Leave him alone; he'll come round, and take 
himself home most likely; said Mr. Mygale, who made but a poor luncheon himself, and as soon as he had finished, went to his den and wrote the following letter to Mrs. Meadows :-

'Su'tTon Park, December 2Sth.

'My deAR Madai,

Your boy has been a source of great amusement, and, I may say, of happiness to me for the last few days; and I thank you for lending him to me. We

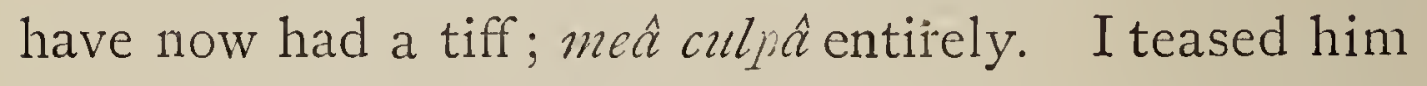
beyond endurance, and, I believe, he has decided to leave me, at which I cannot be surprised, though I am exceedingly sorry. If you will trust him to me again, and can persuade him to return, I think I can promise nothing of the kind shall occur again.

'Yours faithfully,

'Richard S. Mygale.'

He had just directed this letter when the door opened, and Claude, with red eyes and swollen features, walked in. He went straight up to Mr. Mygale, and, climbing on to his knee, whispered,-

'I am sorry I was so rude to you; I didn't mean it a bit, really, only I was in such a temper.'

'Never mind, child; it was all my fault. I have told your mother so in this letter, which you may give her, if you will, when you get home.'

'Must I really go home? Please let me stay; I will 
be as good as ever I can if you will let me stay with you ; will you, dear Mr. Mygale?'

'Will I ? Why, I thought you wished to go. I am only too glad to have you, if you'll stop, and I won't tease you again.'

'Oh! thank you, you are kind to me; I don't deserve it, I know.'

'Umph!' grunted Mr. Mygale; 'suppose we go out for a walk, shall we?'

'Yes, please; only I shall have to write to mother, or else go and see her, if you'll let me.'

But Mr. Mygale thought it better to go out first, and promised to send Martin with the letter to Mrs. Meadows before dinner; he was very curious to know what Claude would say to his mother; so when the boy handed him the letter to read before closing it, he rejoiced inwardly.

'I am afraid the spelling is rather bad, isn't it ?' said Claude, as he put his effusion into Mr. Mygale's hands.

'Never mind the spelling, the matter is very good,' said Mr. Mygale, as he read as follows :-

\section{'My DeARest Mother,}

'Mr. Mygale and I quareled to-day; it was my fault; I got into a rage with him because he teesed me; fortinately Martin was there, and stoped me from fiting him, or the consquents might have bin serius. I am afrade I have broken all my promice now, because there is no chance of my keeping the secret part, is 
there? I have been crying, but I shall feel all rite when you get this letter. Mr. Mygale and I are frends again; we made it up almost directly. Love to the little ones.

\section{'Your loving son,}

'Claude Meadows.'

'Martin may take my letter as well as yours. I should like your mother to have my version of the story also ; and he can wait for an answer.'

Claude was in a subdued frame of mind all the evening, and Mr. Mygale noticed he with diffculty restrained his tears when he read his mother's letter; but he was as happy as a ling the next morning when they resumed their lessons.

'We begin the Leapers to-day, don't we?' he asked.

'Yes; they are distinguished by the large size of the cephalo-thorax, and by the rapidity with which they run and leap on their prey. The first genus, Eresus, has only one British species, cimabarimus; its cephalo-thorax is about the same size as the abdomen, and its legs and falces are short and strong. It is a very rare species indeed. I have one; there he is, that red and black spider; I caught him because he is not so active as the Salticida generally are, though he can leap; he spins long threads on bushes to entangle his prey, though he goes out hunting also. We have no less than seventeen British species of Salticus; a very common species is scenicus, easily recognised, because 
its body and legs are striped with white marks like a zebra, and it runs about very quickly, whether the surface it is traversing be horizontal or perpendicular ; it springs and leaps constantly, but before it takes a jump secures itself by a thread to the spot it starts from. The mother makes a silken cell in some crack or cranny, and there deposits some cocoons. The species distinctus also makes a cell for her flat cocoon in a stone wall, where I have sometimes found the cocoon in July; it is like Esau, hairy. Salticus cupreus makes a very slight cocoon, but her nest, of close white silk, is very neat; it is generally smeared with a little earth outside, but inside it is lined with the silk, and in it the mother lays her eggs; it is to be found in various places, sometimes in the inside of a leaf, or under stone, or in the bark of a tree, or any other convenient nook. The spider varies so much in its markings that it is not easy to describe, but the cephalo-thorax is small. Perhaps the most curious of the Saltici is formicarizs, which, as its name implies, resembles an ant in shape; indeed, it is no doubt often mistaken for one: it is very rare indeed in this country, in fact, it is only found, I believe, in Scotland. The mother makes a very small nest, open at both ends, and flat; it contains a little round cocoon, and is generally placed either under a stone or among the bark of trees. This spider is peculiar in its habits; when pursuing some tempting morsel in the shape of a small fly, it moves slowly, sometimes 
raising itself up by stretching its legs into a perpendicular position, to see if any danger is approaching, and if so it darts away with great quickness.'

'I suppose it is the spider's way of standing on tiptoe,' said Claude.

'Perhaps it is. Then there is a rare species, called by a very long Greek name, xanthogramma, a yellowish spider, of average size, with a large cephalothorax and emerald-green eyes. Salticus floricola has thick, pale, hairy legs, with dark rings on them, and a brush or pad of hairs below its claws.'

'I suppose that brush is to clean its web with?'

'No doubt. Then there is a little Salticus, found in woods, called reticulatus; it is light brown, with strong, pale, hairy legs, and that also has a small brush below the claws.

'And now, I think, we may as well go on to the next family, the Thomisida, which is distinguished by the manner in which the legs are jointed,-in such a fashion that they spread out straight from the body, and enable the spider to move in any direction, backwards, forwards, or sideways. The first genus is Thomisus, or binder. These spiders are short and broad; the males are often smaller and darker than the females; the two first pairs of legs are remarkably long and strong, and all the legs spread out laterally.'

'What does laterally mean, please?'

Sideways. The eyes of the Binders are nearly all the same size, and are arranged crescent-wise; the 
falces are short, and like a wedge in shape; the cephalo-thorax is large, the abdomen short and broad. One of the commonest species is cristatus, but there are several varieties of it. It is thinly covered with short black hairs. The male is much the darker, the legs are strong and hairy, and the four front legs are armed with spines. Cristatus is one of the high-flying spiders, which rises in the air on its silken thread, and is carried by the wind to great distances. As it grows older, it is less aspiring; but during its youth it delights in these aëronautic expeditions.'

'I should like to find a young cristatus very much.'

'You must wait till the spring; it is common enough from then until the autumn. You will find it on low bushes; it has a habit of spinuing threads from branch to branch, which serve it as roads on which to pursue its prey. In the spring, it feeds chiefly on flies; but during the autumn, I regret to say, it develops cannibal propensities, and devours young spiders. July is the month to look for its cocoon, which you may probably find in a rolled-up leaf, or perhaps fastened to a stone. There are nineteen British species of Thomisus, so I will only mention those which have any peculiarity. One species, citreus, has very good taste, for it makes its home among flowers, in which it is chiefly to be found The sexes differ very much in colour, and the female 
is much larger than the male; she is generally yellow, with some green and brown marks, and the male is bright green, with black stripes. The species luctuosus is found in pastures and woods; the little flat white cocoon you must look for in June, and you may very likely find it and the mother together, in a fairy-like bower made of two leaves, joined together by silken threads; the spider is about the same size as her cocoon. Another species, bifasciatus, folds two or three leaves down to make a sort of shelter for her cocoon, which is flat and white. A rather rare species is erraticus, and the female generally fastens her cocoon to the side of a dead leaf. And now, I think, we may go on to the second genus, Philodromus.'

'That means a lover of running, didn't you tell me?'

'Yes; and with their strangely-jointed legs they can and do run in any direction. They are rather small spiders; the females are about a quarter of an inch long, the males smaller. The legs are long, and the two claws of the feet are furnished with brushes; the cephalo-thorax is short and broad; the abdomen, which is egg-shaped, overhangs it. We have nine British species, one of the most interesting of which has a very hard name, cespiticolis. It is found on heaths; the mother makes a nest for her cocoons on some bush, at the end of a branch; she draws the leaves together with silken threads, and fills up the 
interstices with a grey web. She is a brave little creature, and defends her cocoons with her life, if necessary. A species with rather a grand name is aureolus. This spider makes a little white silken cap for its cocoon, and binds it down upon either a wall or the trunk of a tree with silken threads. Variatus and mistus make very slight cocoons. The last genus, Sparassus, contains only one species, smarggdulus, but that is a very handsome one.'

'Is it this lovely green spider in this case, or the yellow and green one?'

'It is both; the green spider is the female $S p a$ rassus smaragduinus; and the other, with green cephalothorax and legs, and green, yellow, and red abdomen, is the male; and, as you see, he is smaller than his wife, who is rather more than half-an-inch long. The legs are very long, the second pair the longest; they are also strong and hairy, and there is a brush under the claws. This is a very quick spider, and runs about very rapidly on the ground. The cocoon is large, green in colour, and round, but slightly made, so the mother constructs a cell for it out of a few leaves, which she binds together with silk. Now, that will do for to-day; but, by the way, before you go, I want to tell you about a foreign wolf-spider, which I forgot to mention, which is very remarkable- $L y \cos \alpha$ Tarentula.'

'Oh! I have heard of the Tarentula; it makes people dance, doesn't it?' 
'So the Italian peasants believe, and learned men used to think so; but that is all nonsense. I dare say it may make them jump if it bites them, for, like all spiders, it has poison-glands, and its bite is very venomous. By the way, you have not got hold of quite the right story about the Tarentula. The superstition is that the effects of the bite can only be cured by music; so, when people were bitten by a Tarentula, instead of sending for a doctor they sent for a musician, who usually found the patient in an unconscious state; but, as the fiddler begins to fiddle, the patient revives, and presently gets up and begins to dance to the music, and goes on dancing for five or six hours, when he is put to bed exhausted. He is allowed to get several hours' sleep, and then he is awakened by the music, and up he gets, and dances away for another five or six hours; and this game is kept up for a week, when the patient refuses to dance any more, and wakes up and knows nothing about it. That is the story, but, as far as I know, there is not a word of truth in it.'

'But there is a Tarentula, isn't there?'

'Oh dear, yes, it is the largest European spider; a full-grown one is nearly an inch and a-half in diameter; it is brown, with black and white marks, and is generally found in the warmer parts of Italy, on dry sunny plains; it lives in holes in the ground about four inches deep. There are some foreign spiders whose bite is so venomous that people have 
died from it; but I can hardly credit the report of one naturalist, who says there are species which, if a man treads on them, will sting him through the sole of his boot.'

'He must have been mistaking a scorpion for a spider, I should think,' said Claude.

'Well, he might, but it is not a mistake a naturalist would be liable to make. However, we have no British spiders which can inflict a serious wound on us, though some people entertain as violent a prejudice against spiders as if they were scorpions.' 


\section{CHAPTER IV.}

THE STORY OF THE PORTRAIT.

'And God made every thing that creepeth upon the earth after his kind : and God saw that it was good.'-Genesis i. 25.

HE next morning Mr. Mygale could not find Claude when the hour for their lesson arrived; he was a very punctual little man, so, after fidgeting about for five or ten minutes, he went to have another look for him.

'I suppose he is getting tired of me and my hobby,' he muttered to himself, as he went to the kitchen, to see if Claude were entertaining Mrs. Martin with some of his prattle.

' $\mathrm{He}$ is in the large dining-room, I think, sir; he asked me to open the shutters a little while ago.'

'What is he doing there, I wonder ?' muttered Mr. Mygale, as he went towards the dining-room, from whence the sound of Claude's merry whistle soon told him he was on the right track.

Yes, there was Claude, with his hands in his pockets, his golden head thrown back, standing before the 


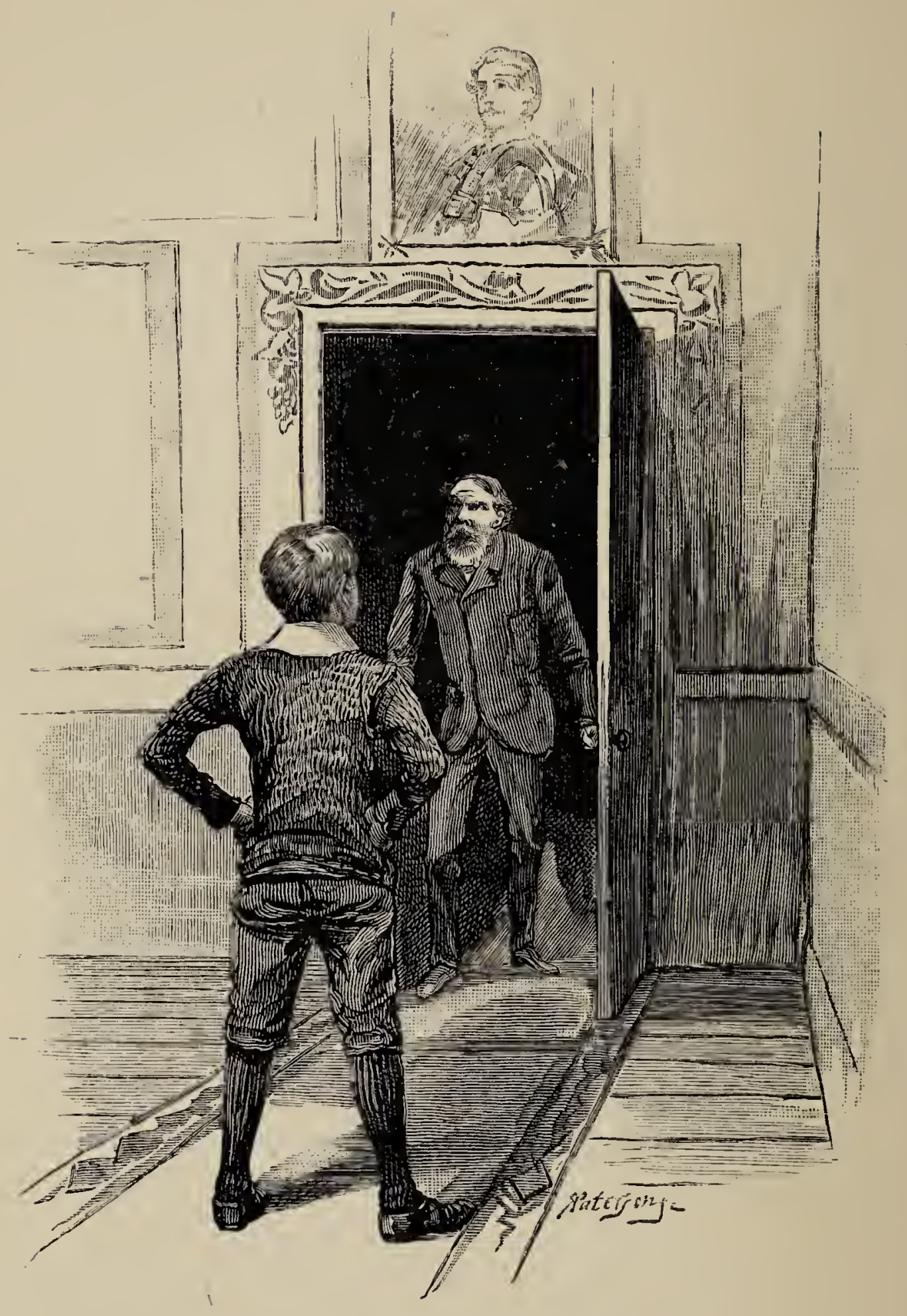


portrait which had struck him as so strikingly like Mr. Mygale. It hung just over the door, which was open, so the boy, with his back to the light, was facing Mr. Mygale as the latter reached the threshold.

'Well, boy, what are you doing here? Do you want a holiday to-day?'

'No, no, rather not! Oh! do just stand quite still a minute, will you, please? It is the very image of you; he was a bigger man, though, but the eyes and the mouth are exactly like yours, and he has beautiful little hands, like yours, too. It is a funny thing that you should be so like him when you are no relation, isn't it? Just come and look at it, will you? You'll see it is not all my fancy.'

'Tut, tut, tut! what does it matter who the picture is like? Come to your spiders, unless you want a holiday.'

' Oh! no, I don't. I'll tell you what I think it must be; I dare say, when you came to live here, you brought a number of things with you, and this picture may have been one; and Martin has made a mistake, it is not a Sutton at all, but a Mygale:'

'Martin has made no mistake, it is a brother of the last baronet. One of these days, perhaps, I'll tell you his story.'

'Oh, thank you! tell me to-day, will you, please? I long to know it.'

'We'll see; let us turn our attention to the 
Drassida, or Seizers, first ; they are a most interesting family, for one genus contains the most wonderful of our water-spiders. The Drassidce all make silken cells, in which they hide, sometimes in crevices, more often in leaves; part of the leaf is often used as the roof to their silken bowers, which are generally open at both ends. The first genus, Drassus, or the Seizers proper, contains fourteen British species; they all have strong legs; the eyes, tolerably equal in size, are placed in two transverse rows; sometimes on tubercles; the feet have two claws, and sometimes a brush, and the sexes do not vary much in size, though the male is usually the smaller. Drassus ater, as its name betokens, is nearly black; it is nocturnal in its habits, prowling about at night on hunting expeditions; the mother makes a beautiful large white cell, under a stone or in a hole in the earth; here she retreats, with her cocoon, in May, and guards it most carefully, attaching it with silk to the foundation of her cell; the cocoon is pale yellow, but it becomes a pale red before the eggs are hatched. A species very like ater, but to be recognised by its smaller size and its red and yellow legs, is pusillus; it is slender, and, but for the legs, quite black. A rare species is lucifugus; the female is half-an-inch long, and very dark in colour ; it makes two cocoons, large, flat, and white.'

'How large are they?'

'Nearly, sometimes, quite an inch in diameter; they are sometimes fastened to a stone, oftener put into a 
tubular cell on the ground; they contain yellow eggs, and are to be looked for in June; the young spiders are reddish in colour. There is a species called sericous, which is found in the north of England, and also in Wales, in old houses. Drassus lapidicolens constructs a snare of threads in front of her cell, which she makes under a stone, using the earth for the foundation and the stone for the roof; here she puts her cocoon, which at first is flat, but swells to a circular shape before the young are hatched; she covers her cocoon with dead leaves, and hides herself in the cell till some time after the young brood is hatched; July or August is the time to look for this cocoon. Then I must not forget to mention a very pretty little Drassus; see, there is one in this case; nitens is its name; if you get it in the right light, the abdomen, which looks black now, has beautiful metallic colours.'

'I see, it is purple and green, like some beetles, and it has some pretty white marks too.'

'Yes, you may find it in the spring or summer running about the ground; it makes a small cocoon, to which is attached a white silken tube, where the mother lives.

And now, I think, we will go on to the genus Chubiona; in this genus the spinnerets are conspicuous, in other respects it resembles Drassus very much, but the males are generally smaller and slenderer than the females. The species amarantha and holosericea 
resemble each other so much in their habits, and in the shape of their cells and cocoons, that I will take them together. The cell is a long tube divided into two chambers, and in June you may find both the male and female spiders at home, each occupying a separate apartment; the cocoon is small, and is placed in the mother's chamber; she only leaves it to seize upon any insect unlucky enough to pass by, which she kills, and drags into her cell to devour at her leisure. She is timid until her young ones are hatched, and, if disturbed, feigns death; and, when the danger is past, runs away and builds a new home in a new place; but when her little spiders are hatched she defends them with her life. Her cocoon is very liable to be eaten by other spiders, and is often attacked by insects ; there is some insect, I don't know what, which lays an egg in the cocoon, and when it is hatched it eats up all the young spiders.'

'But I wonder the mother does not find the strange egg out, and turn it out of the nest,' said Claude.

'She does not even find the larva out till all her own eggs or young spiders are eaten; but both amarantha and holosericea feed largely on the eggs of other spiders, so they deserve their fate. Holosericea is common in woods, on leaves and flowers, or in holes and crevices, or perhaps in the bark of a tree, for in all these places it makes its cell. Formosa is a very rare species, and so is comta, and rarest of all is mutrix. 
Corticalis makes a very substantial cell of grey silk, into which are woven particles of sand or earth and scraps of insects; this strange dwelling-place is

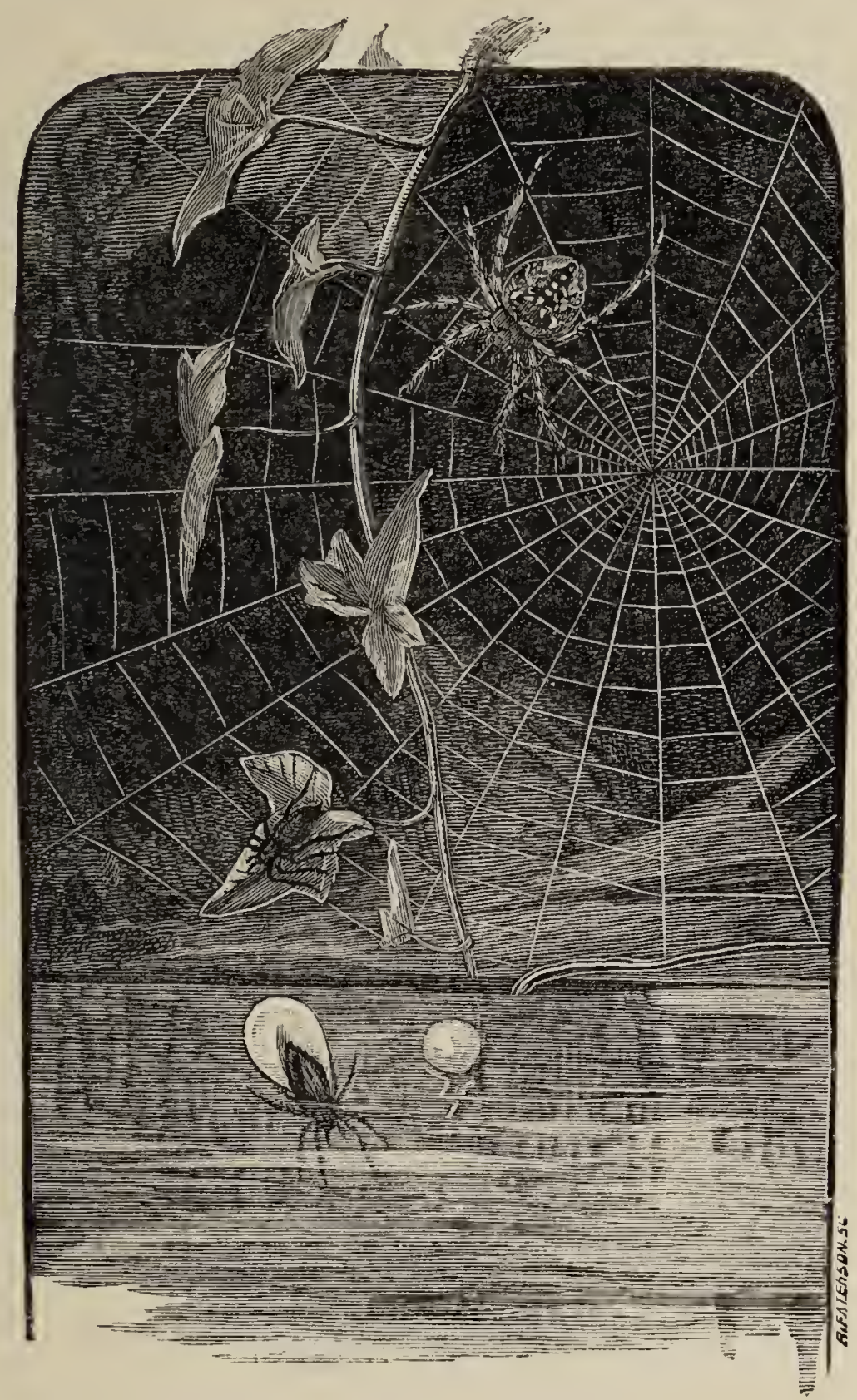

fastened in a crevice in the bark of a tree, or under one of the leaves; the cocoon is to be sought for in July, it is small, and flat, and white. One of the Clubionx brevipes has the power of leaping. Then 
there is a species to be found in woods, darting about the ground very quickly, which is easily recognised by two accent-like marks on the abdomen, from which it gets its name of accentuata; it hides its cocoon in a cell, and does not take the trouble to defend it if it is attacked, but runs away, and leaves it; the cell is made on the under-side of a leaf, which is curved round to hold it. The species erratica remains in her nest with her young; she fortifies her cell by binding together some of the leaves of the furze among which it is placed.'

'How many British species are there?'

'Twelve; but I have told you about all that have any striking peculiarities. Now we come to the third genus, Argyroneta, which contains but one British specimen, aquatica, but that one is one of the most, if not the most, remarkable of all our British spiders. This spider has thick legs, and three claws to the feet ; the abdomen is egg-shaped and very hairy : the hairs of the under surface of the body are very long, the colour several shades of brown; the fangs are powerful; the female, in this instance smaller than the male, which as you know is not generally the case among spiders, is about half-an-inch long. It has several English names: it is sometimes called the water-spider, a misleading name, because, though it is the most remarkable, it is by no means the only water-spider; it is called the silver-spider, and the diving-spider. Now, I dare say you have sometimes noticed, as you have 
walked by the side of a river or canal, a little silver bubble darting about in the water; if you have, you have most likely seen Argyroneta; I don't say certainly, because there is a common insect, called the boat-fly, which has the same power of silver-plating itself.'

'Does it look like a little beautiful silver egg?'

'Yes, very much indeed; but your language is more graphic than mine.'

'Well, then, I have seen it; but, of course, I don't know whether it was the boat-fly or the silver-spider. Is this silver egg the diving-bell?'

'It is the spider and its diving apparatus, at any rate; at least we will suppose your friend was an Argyroneta, and not a boat-fly; the silvery appearance is due to the air-bubbles which it entangles in its long hairs, and these bubbles enable it to breathe under water; it is enveloped in them, and if it loses any air it rises to the surface of the water to secure a fresh supply; when it is swimming or diving it is always in an inverted position. As a rule, Argyroneta comes to the surface for air about every quarter-of-anhour, but it can remain under water for several days together; and during the winter it lies torpid at the bottom of the river, but in its cell, which I will describe directly. Occasionally this spider comes ashore on a hunting expedition, and returns with her prey into the water, but her usual food is waterinsects, which she catches in the webs which bind her cell to the stalk of some aquatic plant; sometimes 
she devours her prey at once, sometimes she merely stupefies it with her poison, and drags it into her cell to eat at her leisure, and sometimes she kills it on the spot, but leaves it in the web till she is hungry.'

'What is her cell like?'

'I am coming to that. It is very like the cell the rest of her family-Drasside, you remember, is her family name-construct on earth, only Argyroneta's being made under water is therefore more wonderful. By the way, though, I have been using the feminine gender in this species; the male, as well as the female, builds a cell and lives in it during the winter. Now the cell, of course, must be supplied with air, since spiders are air-breathing animals, so the first thing Argyroneta does in building the cell is to collect the air for it; to do this the spider rises to the surface of the water with her body topsy-turvy, allows her spinnerets to emerge from the water, catches a bubble of air in them, and darts down to the place she means to build her cell in; here she disengages the air-bubble from her body and fastens it to the stalk or leaf of a plant, and then returns to the surface for another; she continues to do this most energetically until she has collected sufficient air to serve her purpose, that is, until the big bubble is as large as a small nut, then she spins a silk net round it, making the nest into the shape of a diving-bell, with an elastic slit or door on the under-side, to allow her to go in and out at her pleasure; then she fastens the whole cell securely by 
fairy cables to the neighbouring leaves or stalks. In this retreat the Argyronetc passes the winter, and in it she also places her cocoon, which is flat, tough and white, and contains from fifty to a hundred yellow eggs. The young spiders are each furnished with a little air-bubble when they are hatched, and they live in the water. Stagnant water and very rapid streams do not suit the Argyronetce. They prefer slow rivers, or canals, or ditches with running water; and they are found in many parts of England, particularly in the fens of Cambridgeshire. Now have you had enough of spidzrs for to-day, or shall I give you one more family? You see, I want to get through the British spiders before your term of imprisonment is up, so I am obliged to work you rather hard.'

'I am not tired: I wish there were some diving spiders to tell me about, though ; and you won't forget the story about Sir Edward Sutton you are going to tell me, will you?'

'Oh no! But I'll tell you about the Ciniflonida first; they have quite as interesting a family story as the Suttons, though the moral may not be so instructive. Now the great peculiarity of the family of hair-curlers is that they possess eight spinnerets, sometimes one pair, however, is united, and they then have only seven; besides this, they have a peculiar apparatus, called a calamistrum, on the hind legs, which is used in spinning the web; and the web itself is of peculiar construction; in fact, it is more like a net loosely made than a web; 
when it is newly made it is bluish in colour, but it very soon gets dirty-looking, and you might easily mistake it for an old web which has been forsaken. But put it under a microscope, and you will see that, though very irregular, it is beautiful, and composed of one straight thread for a foundation, round which are twisted and curled some very fine silken threads, something like this;' and Mr. Mygale took up a pencil and made a rough diagram to illustrate his meaning.

'Where do they make these webs?'

'Near the holes and corners of walls in which they hide themselves; sometimes the hiding-place and the web are connected by a slight silken tube. The first genus, called Cinifto, have eight spinnerets, strong legs furnished with a calamistrum, three claws to the feet; the eyes, which vary in size, are set in two transverse rows; the abdomen is oval and overhanging; the breast-plate oval or heart-shaped. There are five British species. One of them, atrox, enjoys the doubtful distinction of having a remarkably poisonous bite, which is very quick in its effects, and enables the spider to kill wasps and other large insects, though it is itself only three-eighths of an inch in length. During the winter, atrox wraps itself up in a sort of fairyblanket, made of a woolly web, to keep it warm; it understands how to make itself comfortable, you see, and then it goes to sleep in a hole in a wall. It is a clever creature, for it feigns death if disturbed in its 
web, dropping itself suddenly down on to the ground without attaching itself by a thread. Near its snare, in June, it makes a silken cell for its cocoon, which is flat, and daubed over with earthy particles. Ciniflo similis is very like atrox in appearance, but larger; and the species ferox spins a finer web than atrox, but otherwise resembles it in habit, though it is more given to hiding in dark corners and out-of-the-way places. Then there is a little brown species, only one-tenth of an inch long, which has the lowly name of humilis; though I suspect it owes its name to its insignificant appearance rather than to its character.'

'Is that all about the hair-curlers you have to tell me?'

'I think I have pretty well exhausted the first genus. Now we come to the genus Ergatis, of which we have only three British species; they are all rather small, one-eighth of an inch being the average size of the female; they have eight spinnerets, short legs, with a calamistrum and three claws to the feet; the eyes are in two rows, the abdomen is oval, the breastplate heart-shaped. The ladies of the Ergatis family are less shrewish than the generality of female spiders, they condescend to live with their husbands on amicable terms, and the happy pair together construct the nest. The species benigna and latens weave a snare over two or three spikes of grass-flowers or heath, irregular in shape, and in this loosely constructed nest they deposit their cocoons, three in 
number; those of benigna are white, those of latens green in colour. Slight as the web is, it is capable of catching large flies, and benigna is such a bold little creature that she soon kills them, though several times her own size; her poison fangs are not so long as those of her husband, and this is the case with latens also.

'Perhaps that is the reason they live with their husbands, because the husbands can fight for them and defend them.'

'No doubt you are right; that is certainly the reason we men rule the women of the world; we should not have a chance against them if they were as strong as we are; and I suspect it is the same with the spiders; with them, you see, the females are nearly always the largest and strongest, so the poor gentleman spiders go to the wall. The last genus, Vcleda, has only one British species, lineata, and I have very little to say about it ; it has seven spinnerets, one pair being united; the first pair of legs is very long, and furnished with a calamistrum, like all the family; the abdomen, which is long and oval-shaped, is thickly covered with white hairs; it is yellow, with three brown stripes ; see, here is a specimen.'

Claude looked at the spider Mr. Mygale pointed out; and then, after a little further conversation, reminded him of his promise to tell him the story of the portrait when their lessons were over.

'Well, if you had not been so angry when I teased you the other day, I should not have told you the 
story; but, as it concerns some one who had a very passionate temper, it may perhaps be of use to you to hear it. The portrait you are so fond of is the portrait of onc Charles Sutton, a younger brother of the late baronet, Sir Edward Sutton. Now the baronet was a fine, handsome, good-tempered fellow, but with one great weakness, he was never so happy as when he was teasing; and since his brother Charles had a very passionate temper, easily roused, no one was such a good butt for the baronet's teasing as he was. He was not handsome, as you see, but he had more brains in his little finger than his brother had in his head, and, like many plain people, more particularly, he was very sensitive about his personal appearance. Sir Edward, of course, knew this, and was constantly teasing him about his crooked nose, or his shaggy eyebrows, or his large mouth; and many were the quarrels the two had in consequence, though, to give them their due, they never lasted longer than Charlie's temper, which, if violent, was soon over. As they grew up the faults of their childhood grew too; Edward was still very provoking, Charles very passionate, but they were, naturally, not so much together, for Charles, who had taken honours at his University, was reading up for the bar, and Edward led the ordinary life of a country gentleman; for he was lazy, and heir to this place, so he declined to follow any profession.'

'Did he live here, then ?' 
'Not altogether; he travelled a good deal, but he was the favourite son, and he came home whenever he wished to do so. It happened one winter both brothers were staying here; there were several other visitors at the time, among them a pretty gentle girl, named Alice; her other name is of no consequence; well, both the brothers fell in love with her, quite unknown to each other, until one day the baronet proposed to her, and, to his amazement and dismay, found she was engaged to Charles. Then a teasing fit seized him, and for some days he led his brother a life of teasing, which Charles, being very happy, bore unusually well; but, one day, Sir Edward overstepped the bounds of his brother's endurance, and teased him about his ugliness before his lady-love. As ill-luck would have it, she, seeing Charles was seriously annoyed, left the room; when he turned in a fury on his brother, and asked how he dared insult him in her presence. Edward went on in his usual aggravating way; and how it happened I can't exactly say, but Charles, beside himself with passion, felled his brother to the ground. At first it was thought Edward was killed on the spot, but it turned out he was only stunned, and after a few days was none the worse for the blow; but when he recovered, it was to find that the old baronet had turned his younger son out of the house, paid his passage to Australia, and, with a cheque for $£ 500$ in his pocket, shipped him off to Sydney, to make or mar his fortune as he chose, but never to 
expect another penny from him. In vain Edward urged that he had bullied his brother beyond all bounds, and fully deserved all he got; the old baronet was obdurate, and never forgave his son. That five hundred pounds was all Charles ever had of his father's money; every penny of which, with this house and grounds and furniture, was left to Sir Edward, then Mr. Sutton.'

'And what became of Charles?'

'Well, but for Alice he would have gone to the dogs, as likely as not; but she was faithful to him, and promised to go out to him as soon as he had enough to live upon. This encouraged him, and he did his best; he was, as I said, very clever, and in less than two years they were married, and comfortably settled in Sydney. They had one son, who was like his uncle in disposition, though he did not inherit any of his good looks. When the old baronet died, Sir Edward urged his brother to return to England, but he never did, although they met two or three times, for Sir Edward, who never married, paid several visits to Sydney, and on the last occasion he brought back that portrait.'

'And what became of Charles's son?'

'Ah! that is more than I can tell you. You have heard the story of the portrait, and the moral of it is, "keep your temper"; as the original of that picture did, after the severe lesson he had, which practically made him an exile for the rest of his life.' 
Claude looked very grave after hearing this story, and asked leave to tell it to his mother, when he returned home; but Mr. Mygale would not consent to this, and impressed upon him that it was a secret which he must religiously keep.

The following day, Sunday, to Claude's delight and surprise, Mr. Mygale went to church with him, as if it were his usual custom; though he declared he must have a spider-lesson in the afternoon, to make up for his unwonted piety in the morning.

'Do you know,' said Claude, abruptly leaving the spider question to settle itself, 'I think that story about the picture has two morals. One is, "keep your temper"; and the other is, "don't tease".

Mr. Mygale replied by pulling the boy's ear; but he took the hint, and the spider-lessons were not resumed till Monday morning.

'Now we come to the seventh family, the Agelenide, or Foragers. They make remarkable webs, in bushes or grass, or sometimes in holes, or among dead fallen leaves; they are very closely-woven nets, and the spider lives near them in a strong tube of silk, several of which communicate with the net. The first genus, Agelena, contains nine British species; the principal characteristics of which are, that the spinnerets form a cluster, and one pair is generally much longer than the rest; the eyes are in two curved rows; the legs are rather long; the abdomen egg-shaped, and overhanging the cephalo-thorax.' 
'I wish there was another name for that,' said Claude.

'Well, there is; some people call it the head-chest; if you like to be a baby, you can do the same; but I think the Greek word much prettier, and quite as easy. Don't quarrel with the specific name of the first Agelena I am going to tell you about; it is rather long, but it only means like a maze-labyrinthica, a name given to it in honour of its large and beautiful snare, which you must often have seen on heaths and commons. Perhaps you thought it was the fairies' washing-day, and that you had come across one of their sheets hung out to dry over a low furze-bush or on the heath; for labyrinthica's web resembles what I conceive a fairy's sheet would be more than anything else I know of.'

'What is it like, then?'

'Well, it is a white web, very strong, very closely woven, and large for a spider; it is spread out horizontally, and from it proceeds a long narrow silken tube, running downwards, and very frequently opening into two or three other tubes or chambers, all very substantial, and very beautiful into the bargain. The spider sits at the mouth of the first tube, watching till some wretched fly or other unfortunate insect is entangled in the snare, and the moment it touches the web, out dashes the spider as quickly as possible, and slaughters it. If the spider finds itself in any danger, it uses this tube as a means of escape, dashing into it backwards; and, if followed by its enemy, it 
retreats through an opening at the other end. The mother makes one or two cocoons in August, and hides them in one of these tubular cells. The two species montana and prompta, both of which are very small, are found under stones. Labyrinthica is the largest of the Agelena, and is half-an-inch long; the male is rather less. Elegans is a little spider, and spins a small web over holes in the earth; it makes a tiny cocoon, with only five or six eggs in it, which it fastens to a leaf. Brumnea makes a cocoon of white silk, daubs it over with earth, and then hangs it up by a stalk to a twig. The next spider I have to tell you about is a great enemy of Mrs. Martin's; the woman seems to have some deadly feminine spite against the unfortunate animal, and yet it drapes the walls with finer webs than any human weaver ever yet turned out.'

'I expect that is why she hates it.'

'Possibly; feminine prejudice is the real reason-if such unreasonable creatures as women can be credited with any reason for any of their whims. However, Mrs. Martin's enemy, Tegenaria domestica, belongs to the genus Tegenaria. These spiders have very long thin legs; one pair of spinnerets with three joints, and much longer than the others, three claws to their feet, and the eyes in two rows. The web of domestica is large, and I must confess it is dirty-looking; but it is closely woven, and attached by its edges to the corners of rooms or old buildings. Spiders set a much 
higher value on this web than Mrs. Martin; for, in the first place, they support it by long, strong, and fine silken ropes, both top and bottom; and in the next, if deserted by its owner for any reason, another spider immediately takes possession of it. A tubular cell, in which the spider hides, is connected with the web and the cocoons generally. Several are placed in the web, and daubed with bits of cement or whitewash, which does not add to the cleanliness of the web. These cocoons are large and flat, and found in May. The species civilis resembles domestica in its web and habits; but its cocoons are much smaller, and the spider itself is smaller also. This is a long-lived little creature, living four years, during which time it moults nine times, and the mother produces a great many broods. The other two British species are not remarlkable, so we will go on to the third genus, Calotes, of which we have only one species. This has thick legs, and the female is over half-an-inch long, the male is smaller.'

'Is that the end of the Foragers?'

'No, there is one more genus, Textrix, but it only contains one species, lycosince. It is so called because its eyes resemble those of the wolf-spiders. Its web and hiding-place are like those of the rest of the family-a horizontal sheet connected with the cylindrical cell; near this the cocoon is generally fastened to the under-side of a stone, and darkened over with earth. And there is an end of the 
Foragers. But it strikes me I shall never get through all the British spiders during your visit--imprisonment I mean- unless I go on faster.'

'Why, I can come and see you on Saturday afternoons, if you'll let me. I always come home from Saturday till Monday. May I come?'

'You should, and welcome, but I am going abroad for a few months after you leave me.'

'Are you? I am sorry. Just as we are getting such good friends, too; it is a pity. Must you go?'

'Yes, I must. I am going to look for some spiders I want; and where spiders are concerned everything else must give way.'

'Couldn't you get some one abroad to find the spiders for you, and send them through the post?'

'I could, but there are two objections. One, the spiders would not be half as valuable in my eyes as if I found them myself; and the other, I know of no one in Cape Town I can ask to do it.'

Mr. Mygale did not add that a third reason was that he was afraid he should miss his little visitor so much that he would not be able to lead the lonely life he had hitherto led; nor did he let Claude see how glad he was to find the boy was genuinely sorry to hear he was going away. 


\title{
CHAPTER V.
}

\author{
PLANS FRUSTRATED.
}

\section{'Much like a subtle spider, which doth sit \\ In middle of her web, which spreadeth wide; \\ If aught do touch the utmost thread of it, \\ She feels it instantly on every side.'}

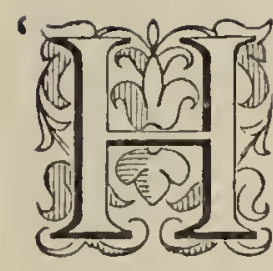

OW do you catch spiders, Mr. Mygale?' asked Claude, the day after he heard of his host's proposed voyage.

'For all moderate-sized spiders I use pill-boxes, and I put each spider into a separate box, and its nest and cocoon, if I am lucky enough to find them, with it; then I write a few observations about the web, or where I found the creature, on the lid. This is much the best plan for beginners; but as I know most species now, I sometimes use a spirit bottle with a large mouth, filled with whisky, and pop all the spiders I catch into it at once.'

'What do you want whisky for ?'

'You want spirit of some kind to kill the spider. Turpentine will do, but whisky preserves the colour 
best. Then I put them into those little glass tubes filled with spirit, and keep them there. When I catch them in pill-boxes, I very often kill them by dropping them into boiling water. Death is instantaneous, so it is not cruel. And then I put them, if they are worth adding to my collection, into the spirit-tubes as you now see them, and write their names on a slip of paper, which I gum on to the bottom of the tube. For rare foreign species I use a net, and I wear very thick gloves, as their bite is sometimes very severe, and even dangerous; but no British species needs such precautions, though I have been bitten slightly several times.

'But let us get on as fast as we can. Let us see. We begin the eighth family to-day, so we have done the larger half. The Theridiidce has only two genera. They all make very fine irregular webs of very thin threads, which cross each other in all directions, and are found in various places-on bushes or branches of trees, or in the holes and corners of buildings. They are more amiable in their domestic relations than most spiders, for the husbands and wives, and the young ones too, all live together in their nest for some while after the little ones are hatched. When these spiders have caught their prey, they bind it with silken threads before they eat it: the Epeirce do the same. The first genus, Theridion, consists of small spiders; the largest female is only a quarterof-an-inch long. They have long slender legs, and 
the abdomen, which overhangs the cephalo-thorax, varies in shape; it is sometimes angular, sometimes round, or notched, or has some appendage. They are quaint-looking spiders generally. A common species is lineatum, which makes a small round, greenish-blue cocoon, carefully fastened to a leaf, so that it is protected by it. Carolinum is very rare, and if you find one you'll find a prize. This species, unlike the rest of its family, carries its cocoon about with it, slinging it to its body with silken threads.'

'Are there many species?'

'Yes, a great many-twenty-six; while the genus Pholcus only contains one species.'

'It wasn't worth making a genus for that one.'

'Perhaps not, but, as you will see presently, it varies too much to be called a species of Theridion. But I don't mean to inflict all these twenty-six species on you, but some are very remarkable. Punctatum, for instance, has a habit of shaking itself and its web violently with its legs - why or wherefore I do not know, though I have often watched the performance. Sisyphum has a fancy for living in large trees, so may be said to be arboreal in its habits. It makes a large but slight snare, and in June makes a silken tent inside the snare for the cocoons. This tent is sometimes made more substantial by the addition of leaves. But the belle of the Theridion family is nervosum; a pretty little spider, which makes, I think, a more beautiful nest 
and snare than any other spider. This nest is as unique a little tent as any fairy can desire to dwell in. It is lined with white silk, but the external decoration is most elaborate. This spider seems to be an artist, or at least to possess an artist's love of colour, for it covers the outside of its tent with scraps of flowers. The yellow stamens are often used, and the wings of insects, particularly those of the green nut-weevil. Sometimes this tent is roofed with a growing leaf, fastened by silken cords into the shape of a dome; sometimes it is suspended in the middle of the snare.'

'And does the spider live in this lovely little tent?'

'When the cocoon is made you are pretty sure to find the mother there with it, hugging it and almost hiding it with her body; it is small, round, and made of green silk; when the young spiders are hatched, the tent becomes a nursery, in which they live with their mother until they are old enough to shift for themselves. The two species denticulatum and varians make their nests in crevices of walls, and trail ivy or some other foliage over them, and fasten their cocoons to a spray or a stone near; denticulatum has only one cocoon, brown in colour, with brown eggs inside it; but varians has several; they are round and white, and often daubed with earth or mortar. Sometimes you may find in one of the snares of the Theridion family a very odd cell, a sort of silken 
tube about two inches long, open at one end and strengthened by little pieces of earth, small stones and dead leaves, which are interwoven into its substance; this is the cell of the species riparinm, and inside it, in August, several pale yellow cocoons may be found. Variegatum makes a pear-shaped cocoon, and hangs it up by a thin stalk to a stone or rock. This cocoon has two coverings; the outside one is made of coarse reddish brown threads; when I say coarse, I mean coarse for a spider; inside this is a little bag of soft, fine, pale brown silk, with about six brown eggs inside it. And now, I think, I have told you all I need about this genus.'

'But you have not finished the family; there is Pholcus to tell me about yet.'

'I have not forgotten. Pholcus, you know, means a "squinter," and the genus gets its name from the strange position of the eyes in the Pholcus; they are on a prominence and on black spots. We have only one species, phalangioides, but it is easily recognised by its eyes and its very long thin legs, which I dare say would induce you to call it a daddy-long-legs; its longest pair of legs are over two inches long. The snare, which is made of loosely stretched threads crossed in every direction, is often spun in the corners of ceilings in houses where Mrs. Martin does not reign supreme. If an insect falls into this web, the spider, by a strong muscular action of its long legs-not, however, peculiar to the species - shakes the web about so 
as to entangle the prey still more, and then sucks its blood. After dining off it, Pholcus removes the remains of his feast from his snare. A peculiarity of this spider is, the female carries her cocoon in her fangs, and after the young ones are hatched, she carries them about in a cluster in the same manner, not fastening them with a thread to her body.'

'Now, do we come to the garden spider? I am so longing to hear about its beautiful webs.'

'No, we have one more family to exhaust first, the Linyphiida, or thread-weavers. These spiders make fine webs, stretched horizontally between branches, like fairy hammocks; sometimes these are kept in their place by fine lines fastened underneath them. The spider is very often found hanging on to the under surface of the web, with its back to the ground. In the first genus the legs are long and thin, and the eyes in two rows, and, in many cases, on black spots; the feet have three claws, and the fangs are toothed on both edges. This is a large family, three out of the four families containing a great many species, which I dare say will take us several days to get through. But to begin with limyphia, or the threadweavers proper; we have thirty-three British species of them. They are little spiders, the females varying from one-fourth to one-twelfth of an inch in length. One of the commonest species is montana; it is also one of the largest; its snare is made in hedges and shrubs or bushes. Above the usual horizontal sheet 
montana often spins some long threads, which form a very high pyramid; and, not content with this, it also secures the web by long threads, which hold it down; so it is first suspended and then staked firmly down, and, when finished, a beautiful aërial building is constructed. Like most of the family, montana is generally found in her web with her back to the ground, in which position she runs quickly about her net. Her husband is generally close by, and his long fangs and red and black colour make him easy to distinguish, since his wife is of brownish hue. When her cocoon is made, montanc leaves her snare, and spends her time in guarding her precious cocoon, which she generally hides under a stone; it is flat and white. The species cauta is a dissipated creature; it turns night into day, and is nocturnal in its habits; it builds its snare against walls or banks. Another species, triangularis, retires from public and outdoor life in its old age; and, having had enough of the world, chooses a nook in some ditch, or sometimes in a building, and there lives the remainder of its days.'

'I wonder why it does that?' said Claude.

'I can't gratify your curiosity on this point; neither can I tell you why the species crypticolens chooses to spend its life in dark places like cellars, unless it is that its deeds are evil, so it fears the light of day; and when it can't find a cellar dark and damp enough for its liking, it makes a home under a stone. It has 
another peculiarity; it carries its cocoon about with it, attached by threads to its spinnerets, and an odd figure spider and cocoon present, for the cocoon is bigger than the body of the spider; it is pale brown, and contains brown eggs. The spider is the same colour, with black markings. There are several other common species frequently found in woods, but if you ever come across frenata, it is a prize, for it is rare; the male has very long hairy legs, pale yellow and greenish about the thighs; the spider is glossy, pale brown, with black stripes and spots. And now, I think, we may go on to the second genus, Neriëne, whose name is derived from the Greek neuris, a cord or thread.'

'Are there as many species of the Neriëne as of the thread-weavers?"

'More; there are no less than forty-eight British species; but I have really not much to tell you about any of them, so they won't take us very long. They are small spiders, varying from one-fourth to one-twentieth of an inch, with long bodies, and long but not very thin legs; the abdomen is egg-shaped, the cephalothorax oval; the breast-plate heart-shaped, sometimes garnished with protuberances; the feet have three claws, and the eyes in two rows are sometimes on black spots. A common species is bicolor; the cephalo-thorax is a plain dull red, the abdomen very dark brown with no markings; you may often find it under stones; its snare is like that of the linyphia. The two 
species comigera and bituberculata have a little horn projecting from the palpi of the male. Vagans is given to flying, after the fashion in which spiders fly, and is common in Lancashire and North Wales. Livida makes several very small round cocoons, white and slightly made, fastens them to a stone, and then acts as a sentinel over them. One species is a restless little creature, and can live in three out of the four elements; for though its home is among shrubs and bushes, it frequently takes flights into the air; and though it does not seem to make any water excursions of its own free will, yet if by any accident it finds itself in the water, it can live there for several days. It fastens its one slight white cocoon to the underside of a stone. Several of the male Neriëne have slight prominences on the cephalo-thorax, but you need a microscope to observe them. And here we will stop for the present.'

In point of fact, Mr. Mygale did not give Claude such long lessons in arachnology, or spider-lore, as for convenience-sake are reported here; for he was very much afraid of wearying the child, and perhaps fostering a hatred instead of a love of the subject; but Claude was very much interested, and was anxious to learn all he could before he went home. However, the day before his departure arrived ere they had finished the Linyphiida, and not all his entreaties could prevail on Mr. Mygale to take the gardenspiders out of their turn. 
'We will leave them till I come back from the Cape You can come and spend part of your next holidays with me; I may be back by that time; but to-day we'll finish the thread-weavers, if we sit up all night to do it. The third genus is called Walckcnä̈ra, after a great German arachnologist named Walckenaër. There are thirty-three British species, all, with one exception, little dark spiders, without any markings, frequently glossy; their legs are generally bright red or yellow, and are long but not thin, with three claws to the feet. In many species there are protuberances on the cephalo-thorax; the abdomen is egg-shaped and overhanging; the four middle eyes form a square, and the other two on each side often touch each other, and the eyes are often placed on the prominence. They are all so small that any description of them would be useless without a microscope; and of their cocoons and habits I really know nothing, except that the species acuminata makes a very slight cocoon of white silk, rounded on one side, and about one-third of an inch in diameter, which contains yellow eggs, and is found in the autumn on the under-surface of stones. The species frontata makes aërial excursions.'

'Is that all you are going to tell me about these German spiders? I am rather glad, because now we shall have time to go on to the garden-spiders,' said Claude.

'Indeed we shall not. There is another genus to 
exhaust yet; but the Walckenaëra are not German, they are British spiders.'

'Yes, I know, only their name is German; but, please, make haste over the last of the threadiveavers.'

'We shan't get to the Epëira to-day, though the $P a$ chygnatha is a very small genus; it is a difficult name, but when you know what it means you won't find it so troublesome, perhaps. It means 'thick-jawed,' from pachus, 'thick,' and gnathos, 'a jaw.' They are larger than the last genus, but still small, varying from one-fourth to one-seventh of an inch. The four middle eyes form a square, and on each side of this square is a tubercle with a pair of eyes mounted on it. Their fangs are very large, their legs long and thin; the cephalo-thorax large, overhung by the abdomen, which is oval. The species Clerckit is the largest; it is onefourth of an inch long. The species Degeerii is found in the North of England and Wales, in Scotland and Ireland. And now, as there is time, I think we will go for a walk before luncheon. We shall come across some webs, and I shall see if you know to what spiders they belong; it will be a sort of examination at the end of our course of lessons.'

Claude would very much have preferred to hear about the garden-spiders, but he did not say so, for he found Mr. Mygale was quite determined to tell him nothing about them that day, for some reason best known to himself. 
Claude supposed it was merely to tease him, but in this he was unjust to his strange friend, for the truth was, Mr. Mygale was dreading the boy's departure; and, to insure his coming again at some future time, he determined to tell him nothing about the garden-spiders, hoping his curiosity on the subject would induce him to return. The lonely man had grown so fond of the boy that he thought his loneliness would be insupportable when he was left alone again; and it was quite as much to escape from this as to procure spiders that he had determined to make a trip to the Cape, though it was quite true he had heard of some very large spiders there which he wished to possess.

But if Mr. Mygale was sorry to lose his little guest, Claude was also sorry to go, though, child-like, he was glad to get home again to his mother and the 'children,' as he called his little brother and sisters.

After he was gone, Mr. Mygale roamed aimlessly about the great empty house, which no longer resounded to the boy's merry laugh and whistle, or to the cries of 'whoop' which had recently frequently echoed through it. Then he had his tea and his dinner by himself, and as Martin placed the decanters in front of him before leaving the room, when the dreary meal was over, he said, abruptly :-

'Martin, I see there is a steamer sails next Tuesday for the Cape; have my things all packed ready. I shall leave here by the mid-day train on Monday.' 
'Can't live without that blessed child, I guess; well, I am glad he has found out there is something better worth caring for in this world, wicked as it is, than a spider,' said Mrs. Martin, when she heard the news.

But 'man proposes and God disposes,' and Mr. Mygale did not sail for the Cape that Tuesday, after all. He went to church on Sunday morning, to the great delight of Claude, who was also there, and invited himself into his pew, and, after the service, introduced his elderly friend to his pretty mother, from whom Mr. Mygale learnt that Claude was to go back to school the next morning.

'I am leaving home to-morrow morning also; I sail on Tuesday. I have hastened my departure, in order to be back by the end of next term, when I hope you will spare me your boy again,' said Mr. Mygale; and, after a few more commonplace remarks, they took leave of each other.

Mr. Mygale was to leave Sutton Park about twelve on Monday morning; the fly was already at the door, and Martin was ready to accompany his master as far as the station, when it struck Mr. Mygale it would amuse Claude to hear that he had left home by the trap-door instead of going out like a rational being. So he called out his intention to Martin, and, returning to his study, opened the trap-door, and, as there was not much time to lose, began hastily to descend the ladder to the tunnel; but, in his haste, he missed his footing, and fell to the bottom with an ominous crack, 
which told him he had broken a bone; and, on trying to rise, found he was unable to move one of his legs. He shouted to Martin, but for a minute or two his shouts were ineffectual, for Martin was outside gossipping with the flyman.

' Umph! it is no use my shouting till he comes indoors; chat, chat, chattering to that fool on the box about nothing, I suppose, while I am lying helpless here!' grumbled Mr. Mygale.

Five minutes elapsed, and no Martin appeared, and Mr. Mygale, who was in great pain, began to feel faint, when it suddenly struck Mrs. Martin to look into the study, to see if her master had left any of his belongings behind him, and the first thing that caught her eye was the open trap-door.

'That there door may as well be shut up till the master comes back again, or we shall be breaking our legs over it,' muttered Mrs. Martin, advancing to shut the door, always an eyesore to her, when, just as she reached it, a feeble moan from beneath the floor. startled her.

'This house is a-haunted, I always said it was; I'll lock this room up till master comes back; and, as for this trap-door there, that won't be opened again in a hurry, I'll warrant!' said Mrs. Martin, shutting the door down with a bang.

Mr. Mygale resigned himself to his fate, reflecting that, as Martin knew where he was, he would soon be discovered. 
Presently, just as Mrs. Martin, having shut the shutters, was locking the study-door, her husband appeared.

'Where is the master? He will never catch the train. He was coming out by the tunnel, but there is no sign of him, and I can't find the door on the grass; I never can.'

'The master! why, I thought you had started. Martin, I hope nothing has happened to him. I heard a groan down in the tunnel when I came in, but I thought it was something uncanny,' said Mrs. Martin, opening the shutters again much faster than she had closed them.

Meanwhile Martin had opened the trap-door, and discovered his master lying helpless at the bottom of the ladder.

'Dear, dear, sir! are you hurt?' asked Martin.

'Of course,' whispered Mr. Mygale.

Martin fetched some restoratives at once, and administered them to the patient, who then revived sufficiently to give some directions.

'Send the fly for Dr. Bates, and tell him I have broken my thigh, and he must bring plenty of assistance to get me out of this trap.'

'I could do that for you, sir, if you'd let me,' said Martin.

'And make a simple fracture into a compound; no, thank you; here I lie till the doctor comes, and puts me into splints; and then, how you are to get me up, 
heaven only knows; send the flyman off, and then fetch some rugs and pillows; I am none too warm, I can tell you.'

Mr. Mygale, though prostrate with a broken leg, and helpless, was still master in his own house, and he, very wisely Mrs. Martin said, obstinately refused to be moved until the doctor arrived, which was nearly two hours; and then he insisted on having his leg set before he was moved, though the doctor assured him the difficulty in getting him safely out of the hole into which he had fallen was so great that the chances were ten to one the leg would have to be reset when he reached the study. Mr. Mygale, however, was firm, and bore the pain of setting with the courage of a martyr. Then came the most difficult part, viz. how to carry him safely up the awkward ladder; but, fortunately, he was very small and very light, and he had his wits about him, and, to the amusement of Martin and the doctor, gave directions himself as to the best way of carrying him. A wide plank of wood was fetched, and on this he was at last safely deposited on a bed in his study, without displacing a bandage; but it was four o'clock in the afternoon before this was accomplished.

'How long shall I have to lie here, doctor?' he asked, when he was finally settled on his hard couch.

' Six weeks.'

'And then hobble about on crutches for another six, I suppose?' said Mr. Mygale, aloud; adding, in an 
undertone, 'Umph! no voyage to the Cape for me ; no Mygales, and, worst of all, no boy to amuse me. What an idiot I was to let that child go away so soon! if I had him here, I should not mind my imprisonment; I wonder why I miss him so; I wish I had never seen his face. What does his pretty mother want to send him to school for, I wonder? I could teach him more in a week than he'll learn in a month at school. But where is the use of grumbling? I dare say the child was sick of me, and my spiders, and cobwebs, too!'

Probably Mr. Mygale did not quite believe this, though he said it, but he was in the mood to take a gloomy view of everything. He had a bad night, and was very low when the doctor came the next day. As the week wore on, his spirits seemed to sink lower and lower; and on the Saturday morning the doctor told the Martins he was very anxious about their master.

'This won't do at all! I shall have him down with low fever if this goes on, and then I won't answer for the consequences. Has he no friends or relatives? He wants rousing; he is moping himself to death alone in this house.'

'No, sir, not a soul that I ever heard of; people have given up calling on him long ago, as he never would see them,' said Martin.

'There's young Master Meadows. If he were here, master would soon pick up; he was not the same man while he was here,' said Mrs. Martin. 
'Master Claude is gone to school, or he would have been over to see the master. He comes home to-day, till Monday, though, I believe,' said Martin.

'Then send for him by all means,' said the doctor ; 'or, better still, I'll go myself,' he added; 'I know Mrs. Meadows; don't say anything about it to Mr. Mygale.'

The result of the doctor's visit was, that about three o'clock that afternoon, just as Mr. Mygale was getting fidgety and restless, and Mrs. Martin in despair lest he should move his leg, a tap was heard at the study door, and the next minute Claude, panting for breath, was leaning over the bed.

'I have only just heard of your accident! Dr. Bates told mother to-day! I came off directly I got home! I am so awfully sorry! Does it pain you very much?' and the blue eyes looked very grave, brought, as they were, for the first time into contact with the mystery of suffering.

'Sometimes. So you have actually spared half-anhour of your holiday to come and cheer up a poor old cripple, have you ?'

'Half-an-hour! I'm going to stay till Monday morning, if you'll let me. Dr. Bates says I may, so does mother, and I can help to nurse you, 'cause I am rather a good hand at nursing. You see, we have three children, and mother is not very strong, so I am used to it.'

Whereupon this experienced nurse took up his 
position at the head of the bed, as if it were his place; and, producing a volume of Hans Andersen's Fairy Tales, began to read aloud to his delighted patient. As he read, he was shocked to see, when he paused for a minute, that one or two large tears were rolling slowly down the wrinkled cheeks.

'I am afraid the pain is very bad; can I do anything for you? I must not rub it, I suppose,' he said, doubtfully.

'Hardly; massage is not yet recommended for broken limbs that I know of, but I am not in much pain.'

'It was rather a sad story; I'll choose a comic one this time; or are you tired of being read to?'

'Scarcely; no one has read to me since my mother died, till to-day. Go on, and if I go to sleep don't mind ; I have had very bad nights lately.'

So Claude read on, and in a short time found his patient was sleeping peacefully; so, leaving Martin in charge, he crept downstairs for his tea. There he teased Mrs. Martin to make up a bed for him on the sofa in the study.

'You see, I don't think we ought to leave Mr. Mygale alone all night; if he wants anything, I can get up and get it for him. I do sleep rather sound, I am afraid, but I'll give him my sponge, and he can shy that at me if he wants anything.'

So, to Mr. Mygale's great comfort, Claude had a bed made up for himself at the foot of Mr. Mygale's, 
who promised, if he wanted anything, to wake his nurse with a little hand-bell. Claude thought the sponge a more effectual alarum, but this the patient declined to use. When the doctor came the next day he found his patient decidedly better; and, to Claude's pride and delight, he declared the improvement was due to his nursing.

'I shan't go to church this morning, Mr. Mygale; you are a little bit better, so I'd rather not leave you, or perhaps you'll be having a relapse; we"ll read the Psalms and Lessons together at home, shall we?'

Mr. Mygale, who was very much tickled at the idea of a relapse in the boy's absence, agreed to this proposal, and listened attentively to the soothing words of the Psalms read by those boyish lips. 


\section{CHAPTER VI.}

GOSSAMER SPINNERS.

'A threefold cord is not quickly broken.'-Ecclesiastes iv. I 2.

'The spider's touch, how exquisitely fine!

Feels at each thread, and lives along the line.'

POPE.

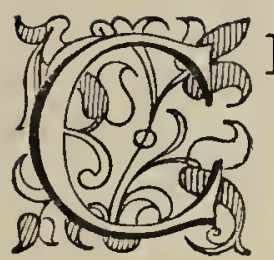

LAUDE was obliged to leave Sutton Park early on Monday morning, but he promised to come again on the following Saturday, if Mrs. Meadows would spare him. Mr. Mygale missed him dreadfully, and took it into his head Mrs. Meadows would certainly not spare him again. He worried and fretted about this till, by the time Saturday came round, he was as bad as ever again, and the doctor took it upon himself to call on Mrs. Meadows and suggest she should allow her boy to miss a week's schooling and spend the time with his eccentric friend.

Mrs. Meadows did not object to this plan, provided Claude and his master agreed to it ; the master, when consulted, decided to leave the decision with Claude, 
who was trying for a prize. If he took this week's holiday, there was no chance of his winning it; on the other hand, he was very likely to gain it if he persevered. This was put before the boy, and Claude, on learning that Mr. Mygale really wanted him, at once said he wished to go and stay with him. So Mrs. Meadows, who had driven over to the school after seeing Dr. Bates, now drove straight to Sutton Park, the gates of which opened wide when Claude's face was seen at the carriage-window:

'Here I am again! what a pity you have had a relapse! I was afraid you would, though; you see I don't think Mrs. Martin understands nursing as well as I do, and she can't hold your hand and coax your head when it aches like I can, can she?'

'Not exactly,' said Mr. Mygale with a chuckle.

'So it is a good thing I came; and I am going to stay till Monday week with you, so in that time I should think you'll get quite well.'

'No doubt I shall be playing leap-frog at the end of it,' said Mr. Mygale.

'No, your leg won't be well ; but if you are better, you'll be able to bear the pain better, and if you are well enough I think we might go on with our spider lessons ; only we must ask Dr. Bates first.'

Dr. Bates was of opinion that the spider-lessons would be worth more to Mr. Mygale than all the drugs in his surgery; so, to the delight of master and pupil, they were resumed on Monday morning. 
'Now I shall hear about the garden spider and the geometrical spider, that I have been longing to know about,' said Claude, seating himself by the bedside with a box of spiders in glass-tubes on his knees.

'I believe you care far more for the spiders than for me; it was Epëira diadema, and not Mygale, that attracted you here.'

'No, it wasn't; I would not have missed the prize I am trying for to hear about spiders now, because I could have waited till the holidays for that,' said Claude, gravely.

'True; you are a very kind boy to have come to me, and I am an ungrateful old cross-patch; however, to make up for my grumbling I'll tell you about the Epeirra. As their webs are so remarkable and so beautiful, suppose we begin with them. You can't mistake the web of this family, its wheel-like form and beautiful geometrical regularity at once identify it; indeed, it is so well known that if you were to ask any one who knew nothing at all about spiders to draw a cobweb, he would in all probability at once draw the snare of Epëira diadema, which consists of a number of lines called radii, all radiating from a centre, like the spokes of a wheel; and then the mesh is formed by a spiral line beginning in the centre, and twisting on and on till the outer circle of the web is completed. Now these two lines, the spiral line and the radius line, are made of two different kinds of threads; the radius line is the ordinary spider's thread, 
but the spiral line is a string of fairy-pearls or fairybeads, each pearl being a tiny drop of viscid matter, which does not harden like the rest of the thread.'

'I have never noticed the fairy-pearls; I suppose you must have a microscope to see them?"

'No, a good magnifying glass will do, and a very beautiful object a strand of these globules is. The web is very elastic, particularly the spiral thread, and, to increase this elasticity, the spider very often removes the centre of the web by biting through the radius lines and leaving a small hole.'

'How does that make it more elastic? I can't see how it should.'

'Well, it is rather difficult to explain, because a mechanical principle is involved in it; however, I will try. You see, if the web were left entire, any pressure on it would fall on more or less tightly strained lines; whereas, if the centre be removed, it falls on an elastic ring, which gives instead of resisting. On the same principle, the outer ends of the miniature wheel-spokes are very seldom fastened directly to any fixed object, but to strong spider-cables, which are again attached to finer lines, so that the web is never subjected to a sudden jerk at the point of attachment. Very often you may find the spider resting in his web, sometimes in the centre, but more often he builds a nest near the snare, and connects the two by a strong thread drawn from the centre of the web; this thread serves a double purpose, it acts as a telegraphic wire to inform 
the spider when a victim is caught in his toils, and it also serves as a bridge or road from the nest to the snare; when the spider is found in the web, he is generally in the centre, with his head downwards. By the way, the centre of the web is not viscid, like the outer whorls.'

'Now I should like to know how this spider makes its web, please.'

'I am coming to that. I see you mean to learn all I can teach you about your favourites. We will take diadema's method of construction as a type of the family; it is going a little out of my usually methodical system, but never mind. The first thing he does when he begins one of his beautifully symmetrical and geometrically-proportioned webs, is to spin a strong cable from two convenient points, and, as much depends on this rope, he is careful to make it very strong, so he often doubles and trebles it; but in the first instance he has to call in the help of the wind, which carries the silk, as it flows from his spinnerets, to a second point of attachment. He completes the framework, or we might perhaps say the scaffolding of his snare, for he uses it as a platform on which to work, though he does not afterwards remove it, by making other lines from the foundation-line and fastening them wherever it is convenient to do so; sometimes he makes these lines by the help of the wind, sometimes by dropping himself down on the thread as he spins it; when his frame is finished he goes to the centre of 
the first line and drops down to the bottom horizontal line, spinning a thread as he goes; then he goes back on this thread to the centre of it, which point he makes the centre of his web, and spins all the radii from it. When these are finished he again goes to the centre and begins the spiral line, which forms the meshes of his net, using his beaded or jewelled thread for this purpose; he fastens this thread with the help of his hind legs. When he has reached the outer circle he turns round and goes back to the centre, spinning a second jewelled thread as he goes. I forgot to tell you that the foundation lines are generally attached in the shape of a $Y$, for the sake of additional strength. There now, do you think you could make a web like diadema's?'

'No, of course I could not,' laughed Claude.

'Well, I have done my best to teach you how to set to work, so now for the family characteristics. There are only two genera, Epëira and Tetragnatha, and the latter has but one British species. The eyes of the Epëira are in three groups, and the four centre ones are in a square; the legs are long, the third pair are the shortest; the feet have three claws, sometimes more, and some species have a spine on the foot, which acts as a thumb, through which the thread passes, a fact known to Solomon, who mentions it in Proverbs.'

'I know the text; mother told me the other day; it is, "The spider taketh hold with her hands, and is in king's palaces."

'That is the verse I meant. Well, it is true that 
some of the family have the power of grasping their threads with their claws. These are large spiders, the length of the female varying from two-thirds to one-tenth of an inch; the abdomen is nearly globular, overhangs the cephalo-thorax, and sometimes has one or two humps, for the Epëira are hunchbacked. We have thirty-one British species, of which the species quadrata is the most beautiful. I have one, that beautiful sage-green and amber creature, with four oval white marks on its nearly round abdomen; its shape and colours make it easy to recognise; but if you wish to possess one, the best plan is to look for its large white cell, shaped like a dome-a sort of fairy Taj-mahal, a dream in gauze, instead of a dream in marble. This is to be met with very often on a furze-bush, and is connected with the web by a strong silken cable. The cocoon is large, two-thirds of an inch in diameter, round and yellow, with yellow eggs. The species cucurbitina hides its cocoon-which in shape and size resembles quadrata's, but is a more brilliant yellow-between some leaves near the web. Another dome-shaped cell is made by apoclisa; this dome is composed of tightly-woven white silk; in the winter this dome is covered with dead leaves, the spider retreats into it, and spins a white silk curtain, to keep out the cold. At other seasons, it is said-but I can't vouch for the truth of the statement--that if disturbed in its cell the spider closes the opening by grasping the sides with its claws.' 
'What a clever spider apoclisa is!'

'He is. Dormice and harvest-mice appreciate the beauty of his silk, for they use his deserted cell to roof and line their own nests with. Now, I must tell you of the black sheep of the family, umbratica, a villainouslooking creature; you know it by sight, I am sure; it is large and dingy, and looks crushed as it sneaks along with its legs sprawling about; it hates the light, and never comes out in the day-time of its own accord; but if you come across its nest, which is peculiar, you may find it hiding its evil, slouching self near, in the hole of a wall or bark of a tree.'

"What is its web like?'

'It is very large, and the meshes are large also; and instead of the radii being divided by spiral lines, the meshes are made by forked transverse lines very irregularly arranged, and the centre of the web looks in a muddle, so that you can't distinguish the radii; both the spider and his web are so singular in appearance that you can't mistake them. The cocoon is round and white, and has bits of wood attached to it.

'But here comes Mrs. Martin with my luncheon, so I suppose we must say good-bye to the Epeira for today. While my soup is cooling, though, I'll tell you a strange thing I once witnessed on board ship ${ }^{1}$. The web of an Epeira on the deck had got foul with soot from the engine, and the spider set to work to clean it, stripping the soot off the lines; but when this was

1 Told by Mr. Rennie. 
impossible, she bit off the foul threads, rolled them up and cleared them away; when she had finished this performance, she set to work to mend her injured web.'

'I have often seen spiders shaking their webs; do you think that is to clean them?'

'It may be, but I think it is much more likely it is to test the strength of the web, though it is an undoubted fact that many spiders do clean their webs, some in the way I have mentioned, using the brush with which the claws are often furnished for the purpose. Some webs, like those of Tegenaria civilis and domestica, are always dirty; "it is their nature to," as the saying runs. And now, what do you mean to do with yourself this afternoon, in this fog?'

'Oh! I shall go out for a little while, if you can spare me; it is bitterly cold, Martin says, but I can run.'

'All right; don't run far, or you'll be lost, perhaps ; you had better confine yourself to the park to-day, I should think; it won't matter much where you go, you can't see twenty yards before you; I expect you will soon have had enough of it.'

Perhaps the wish was father to the thought, for certain it is that Mr. Mygale could not bear Claude to go out of his sight, and the hour his little nurse was absent seemed a very long one to him. The boy returned in a great state of excitement, radiant with delight, and carrying a tray with something on it carefully in his hands.

'I have had a splendid walk; I am so sorry you 
can't come out and see it; the trees are just lovely; they are all covered with frost; and the frost is very thick on them, and they do look such great, beautiful things; they look to me like ladies in ball dresses, just as if they were going to have a party to-night; or perhaps it is a wedding, they are something like brides; if only the sun would come out, how they would sparkle! they would look as if they were covered with diamonds then, only the sun would soon melt the frosting on them. The hedges are all covered with it too, and it is so pretty; and just look what I found-these cobwebs, all frosted. I was obliged to pull them down, because I wanted you to see them, and I have been rather a long time, because $I$ had to go in and fetch a tray to put them on. Look, isn't this a beauty?'

And Claude pointed to a web made by Epäira diadema, which was thickly covered with frost, and certainly was a beautiful object, though in the warm room the frost began to melt; he had also brought one or two of the silken hammocks of Agclena labyrinthica, on which the fog was frozen in the same way.

'Fogs even are beautiful, sometimes, aren't they?' said Claude, as Mr. Mygale admired his treasures.

' They scem to have a silvery side to them, at any rate; but I am inclined to think beauty very often lies more in the eyes of the beholder than in the object beheld. I am glad you managed to get so much pleasure out of what I call a disgusting day.' 


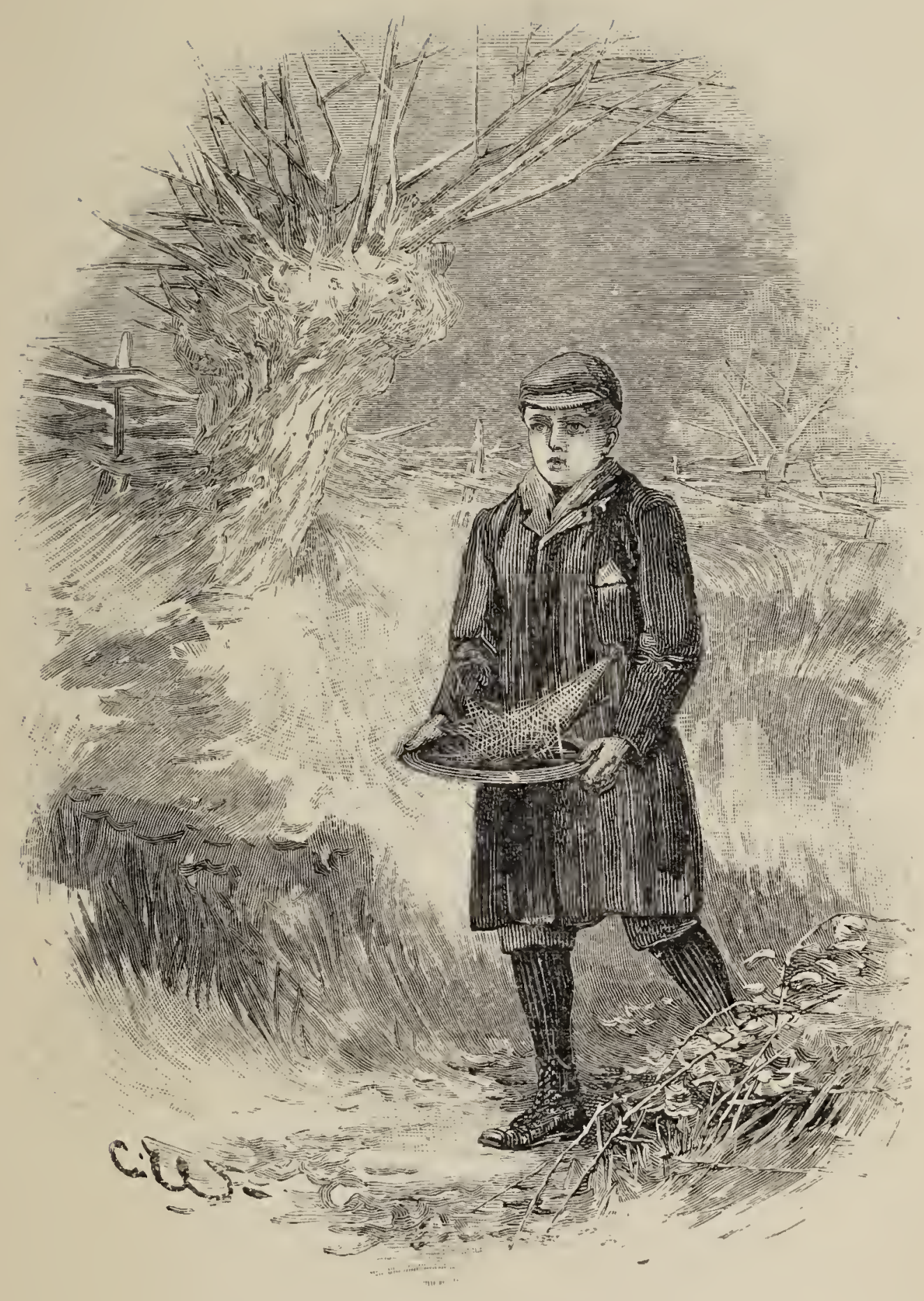



'That is only because you are ill and can't go out. I don't suppose I should admire the fog if I had to lie here and look at it through the window. I wonder when you will be well enough to go to the Cape.'

'Not at all this year, I expect; clambering up and down companion-ladders is not very good for a broken leg newly mended! I shall have to give it up; and it is a great disappointment to me; I want very much to have some of the Cape spiders.'

Claude looked very grave, and, after a long silence, he said thoughtfully:-

'I should like to go home one day for half-an-hour to speak to mother, if you will let me.'

Mr. Mygale gave as gracious a consent as he could by a strong effort force himself to give, but in truth he grudged every minute the boy spent out of his sight, and he had not the least idea what Claude wished to see his mother about; his amazement would have been great if he had guessed; but this visit did not take place till there had been several more spiderlessons.

'To-day we will begin with Epëira diadema, about which you already know a good deal. It has several names; it is generally called in English the garden spider, or the geometrical spider, but the French call it the Porte-croix or Croix de S. Denis, from that cross of white spots on the abdomen. The female is half an inch long, the male much less. I forgot to tell you one very remarkable fact with regard to the 
webs of the Epäira; although they are constructed with geometrical precision, they are made entirely by the sense of touch, for the eyes are situated at the opposite end of the body to the spinnerets; moreover, they are on the upper side, and the spinnerets on the lower; the hind leg is used to guide the thread; sometimes diadema introduces pieces of wood into its net to strengthen it; this is when the wind is very high. I have seen pieces as large as your little finger suspended from the snare of the garden spider. As a proof that the eyes are of no use in making the web, I have shut some diademas up in the dark, and their nets have been as true as that one you brought in frosted the other day from the garden. Like Pholcus, diadema shakes its web, and when a victim is caught, it binds it before it kills it, spinning threads round and round insects as large or larger than itself, until they are wrapped in silken shrouds.'

'Do the poor insects die?'

'No, they live bound until the spider elects to feed on them, so he has a fresh supply of food in his larder.'

' $\mathrm{He}$ is a cruel creature; I don't like him so well now, in spite of his beautiful web.'

'All spiders are cruel; wait till I come to the tiger of the insect world, as one big spider is called, and then you will think diadema gentle by comparison. The cocoon of the garden spider is made in October, but the young are not hatched till the following spring; 
as soon as they are, they begin to spin some invisible threads, and then fasten themselves on these threads into a little tiny ball, which seems to hang in mid-air, but is really fastened to some twig. Now, if you were to disturb this fairy-like ball, it would break up into apparently a tiny puff of smoke, which, in the course of a little time, would collect together again into a smaller ball, for, doubtless, some of the six or seven hundred tiny creatures would perish in the process. By the way, have I remembered to tell you it is the young Epëirc which make the most perfect webs?'

'No, I don't think you have; but you don't mean any young baby spiders, do you?'

'No; I mean young, but nearly full-grown ones, of the spider-age which corresponds to our sweet seventeen. Now, there is a very common species, callophylla, which makes a peculiar web; it leaves one corner of its web free from the spiral line, using a radius as a rope, on which to pass from the centre of the web to the tube-like cell in which it hides itself; in fact, it lives in this cell all the year round. Callophylla has several enemies, which prey on its eggs and on its young; two ichneumon-flies, and two other spiders, besides an Acarus, are among its foes. It makes a round pale brown cocoon, containing brown eggs; it is generally found fastened either to a stone or in a wall. The species fusca makes a very beautiful cocoon, of very delicate white, transparent silk; it is large and oval, and is suspended by a stalk of silken threads; inside it 
is a little ball of yellow eggs, which may be seen through the transparent envelope. This is a species which feigns death when in danger, and its domestic arrangements are, as spiders go, rather happier than usual, for the husband and wife live near each other, although not together; I suppose, because the wife being the larger, she would rule the roost if her husband gave her the opportunity. They are to be found in dark and damp places, such as caves or cellars, sometimes under a bank.:

'A good many spiders seem to like to live in dark holes and corners.'

'Yes; I expect they think their evil deeds don't bear the light of day thrown upon them. The species antriada also loves a dark, damp place for its home; so does celata. There is a species called inclinata, so named because its web is always placed in an inclined position; it is open in the centre, and is to be found on shrubs and trees. If disturbed, inclinata drops to the ground, spinning a thread as it goes, and on this thread it returns to its web when the danger is past. It makes several round white cocoons. This is a small spider; the female is only one-fourth of an inch long, and the male less. Epëira conica is a queer little hunch-backed creature, which looks as if it had been crushed; it is rather rare, though it has been found in several counties. It is small, and makes a small web, in which it hangs the remains of its victims after a feast, whether to warn or to terrify 
other insects I can't say. The spiral threads in this web are very close together, and the web is made in a rolled-up leaf. Tubulosa makes a loose and irregular web on a plant, and then constructs a silken tube near, which it covers with leaves and there hides itself. And now I have come to an end of the Epëira, and I dare say you are not sorry.'

'I liked it all very much, but I do want to finish all the British spiders this week; so I am rather glad we are getting on with them as quick as we can.'

'Umph! when once they are finished, your visits will be like the angels', I suppose, few and far between?'

'Oh, no, they won't! at least, not when I am at home. But you have not told me about the second genus yet, I forget the name of it.'

"Tetragnatha, which means "four jaws"; and a most formidable-looking object these jaws and falces look under a good microscope, for the fangs are very long indeed and spreading, and the falces toothed; the legs are long and thin and hairy, with three claws to the feet; the abdomen is very long, smaller behind than in front. The only British species, extensa, varies in colour: the legs are pale, the two front pairs are very long, the third pair short; but the peculiar long thin body, and the length of the legs, make it impossible to mistake it for any other spider.' 
'Why is it called extensa?'

'Because it has a habit of stretching out its two first pair of legs in a straight line in front of it, and its two hind legs in a straight line behind it, when it is resting. It is generally found near water. The web is loosely made, the centre open, and it is placed in any position; if the weather is likely to be stormy, it moves its web to another place, lest the water should rise and destroy it. In June it makes its little green and white cocoon, which it fixes near the web to a stone or some other object. And now we have finished all the British spiders belonging to the eight-eyed tribe.'

Here Mr. Mygale was interrupted by the entrance of Martin, who brought a note from Mrs. Meadows to Claude, telling him that measles had broken out in his school, and his master had written to say he had better not return till all fear of infection was over.

'Oh! I must go home and see mother to-day, then; may I, please, Mr. Mygale?' said Claude, eagerly.

'If you like. You seem rather pleased than otherwise at the news.'

'Well, I am sorry the boys are ill, but I am glad they have got measles; - at least, I mean I am glad I have not to go back to school, if you can understand what I mean.'

'Your feelings appear to be complicated; but on the whole, if I may venture an opinion, I should say 
joy predominated. But go and see your mother now, and get back in time for luncheon.'

Claude required no second bidding. But the interview with his mother lasted longer than he had anticipated, and he was not back till a quarter-of-anhour after Mr. Mygale's usual luncheon-time, and when he came in he found his friend rather cross.

'I could not help it, Mr. Mygale; really I could not. Mother took such a long time to persuade, I could not get away before; but I thought you would have had your lunch before I came in. And now I have persuaded mother, I am afraid it will take me just as long, if not longer, to persuade you.'

'You had better wait till I have had something to eat before you attempt to coax me over to any of your schemes, I can tell you. I may be in a better temper then than I am now.'

'Yes, you'll be all right when you have had something to eat; invalids never ought to wait for their food,' said Claude, with all the wisdom of his ten years.

'Nurses should not keep them waiting,' grumbled Mr. Mygale, pretending to be more cross than he really was; for the moment Claude returned his irritation subsided.

'And what is this scheme that your mother was so long in consenting to?' asked Mr. Mygale at last.

'Why;' said Claude, 'I wanted her to let me do 
something, and I was afraid she would not; but she has said I may tell you, and if you will let me do it, she will.'

'But what is it?'

'Why, I want to go to the Cape and get those spiders for you,' said Claude.

'To the Cape! Why, boy, to hear you, one would suppose the Cape was in the next village. Do you know it takes three weeks to get to Cape Town? How should a child like you take such a journey as that?'

'Why, you could put me under the care of the captain, couldn't you?'

'The captain, indeed! And pray what would become of you when you landed?'

'Well, I thought you could write to some one out there, and ask them to take care of me, and tell me where to find the spiders, and see me off home again when I have got them.'

'Umph! And pray what put such an idea into your head ?'

'I thought you were so disappointed about the spiders, and I know you won't be able to go yourself for a long time, so, if you will let me, I'll go for you. But I was afraid you would be harder to persuade than mother even, and she only said I might ask you about it - that there would not be any harm in that.'

'Oh, no; no harm at all. The harm would be if 
you went, because I should lose you. I would rather have you to nurse me than possess all the spiders in the Cape.'

Claude said no more. He saw, or thought he saw, that his plan was not approved of, and he was disappointed and very grave for the rest of the day. That night Mr. Mygale was very restless, and, for the first time since Claude had been there, he called him up about two o'clock, and asked for his writing materials, to write a letter. When the letter was finished he put it under his pillow, and said Martin must take it the first thing in the morning, and that now that was done he thought he should sleep.

'I suppose it is to the doctor; I am afraid he is not so well,' thought Claude, as he laid down again.

But the letter was to Mrs. Meadows-not to the doctor. 


\section{CHAPTER VII.}

OFF TO THE CAPE.

' Our souls sit close and silently within, And their own web from their own entrails spin; And when eyes meet far off, one touch is such, That, spider-like, we feel the tenderest touch.'

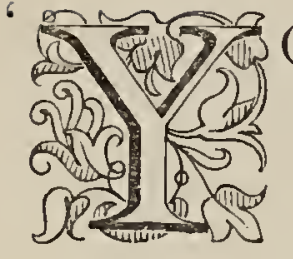

OU won't be well enough to do any spiders to-day, will you?' said Claude the next morning.

'Dear me, yes, I shall; I am quite as well as usual; we will begin at once; and this afternoon I want you and Martin to go to Anntown for me by the two o'clock train, so we must lunch earlicr. I have several things for you to do there, and you can come back by the five o'clock; there is a moon, so it won't be dark coming from the station.'

'I should not mind if it were; I could go anywhere with Martin. He is a capital man, and we are neither of us afraid of anything.'

'That is satisfactory! Well, now for the six-eyed spiders, of which we have very few. There are only two families-the Dysderida, which have four genera; 
and the Scytodide, which have one genus and one species. The Dysderida live by hunting. They make hiding-places of silken tubes in cracks and crannies or under stones, where they lie in wait for their prey, and then dart out upon it. They have six spinnerets, six eyes, and four breathing-holes. The genus Dysdera has moderately long legs. Both divisions of the body are oval, except in Hombergii, where the abdomen is slender. They vary in size from a quarter to half-an-inch, and are nocturnal in their habits. Dysdera erythrina is an elegant creature, with a slender body. The abdomen is creamcoloured, the cephalo-thorax dark red. This spider has a great penchant for ants, and it has been known to make its nest in an ant-hill, where it can indulge its liking to the full, for its long silken tube is so closely woven and so strong that the spider is protected from invasion in this retreat. Sometimes this cell is fastened to a stone on a wall, and in it the spider remains quite still all day, with its head towards the open end of the cell; but in the evening it is wide awake, and darts out of its nest on to any passing insect, and even on to other spiders, for it has cannibal tastes. The species Hombergii is a pretty spider, with a long, slender body. The shield is black, the abdomen pinkish brown. It is common in the North of England. It makes an oval cell of white silk, which it covers with gravel, and there lays twenty or thirty pink eggs.' 
' These spiders here are some of the six-eyed ones, aren't they ?' said Claude, who was looking at some spiders through a magnifying-glass.

'Yes; they belong to the second genus, Segestrix. We have only two species. They are rather large, as you see, and the legs long and strong; the falces are strong and prominent. They are not unlike the Drassi in appearance, but their six eyes, arranged in three groups, prevent mistakes being made. The species perfida is rare, and, if its name is derived from its character, it is fortunate that it is. The other British species, senoculata, makes a white silk cocoon, flat, and daubed with earth, in May or June. The genus Schonobates, or 'the rope-dancer,' has only one species-Walkeri. It is a little brown spider. Smaller a great deal is Oonops pulcher, the only individual of the genus Oonops. The eyes are placed close together in three pairs. The legs are long, with two claws to the feet; these are provided with a hair brush. Oonops pulcher is a pretty little spider, not at all rare, with a yellow cephalothorax, and red abdomen. It lives in the crevices of walls and rocks or on the trunks of trees. It makes several small, round, white cocoons in May, and in each cocoon are placed two pink eggs. And now we come to the last family, the last genus, and the last species of British spiders-Scytodes thoracica. This spider makes a slight irregular web on bushes and in houses, and sometimes in warm places on 
walls ; but it likes warmth, and only comes out on dry and sunny days. It is a quict little creature, possessing none of the ferocity of other spiders. Its poison fangs are weak, and so feeble that it seizes its prey with its jaws generally. It feigns death when attacked, but never attempts to run away or to defend itself. It is a poor-spirited little creature, but it takes great care of its cocoon, carrying it about in its falces without attaching it by threads. It has enormously long and thin legs, particularly the front pair. The spider itself is about a quarter-of-an-inch long. And now you know all I can tell you about British spiders.'

'But you can tell me something about foreign spiders, can't you?'

'I can give you a few scraps of information about them; but I can't go through the different genera, as I have done with the British spiders. There is a Mygale in Ceylon, a great creature, six or eight inches in diameter when its legs are spread out; I have seen them large enough to cover a small plate. It is occasionally found in houses out there, but it shuns society as a rule; it is very sluggish in its habits, and is a disgusting-looking animal. Its body is covered sparsely with hairs, and has a few bands of pale brown across it; the rest of the body is dark-brown. It is nocturnal in its habits, coming out of its tunnel at night to feed on worms, cockroaches and larvæ. The tunnel is beautifully lined with a white silk 
tube, which is stretched out beyond the entrance and makes a little platform; but first, before the monsoon, this platform is stretched out above the entrance, so as to form an awning, which is suspended, or rather propped up, by webs, and keeps the tunnel dry.'

'Is that the Mygale which is said to eat birds?'

'No; that is found in Brazil, in the country of the Amazons, and is called Avicularia. This horrible spider is covered with hairs, which come off easily, and, if they touch you, irritate your skin fearfully. This species spins a very strong coarse web, in which, I believe, birds have been found. One very wellauthenticated instance is, of two finches found in the web of an Avicularia in Brazil; one was dead, and the other covered with a filthy saliva, but I don't think the spider intended to dine or sup off his victims. I read the other day in a book on the Amazons that the author had seen an Indian child leading one of these monsters about the house by a string, as if it were a dog or a toy-horse. There are several species of Mygale out there; some build their tunnels in the roofs of houses, some are scen crawling about the walls of the rooms, some are found in trees. They make dens for themselves of closely-woven web, which looks like fine muslin. One species, called Blondii, makes a tunnel two feet long, which it lines with silk, and about sunset he may possibly be found at the mouth of his tunnel watching for prey; but if he hears you 
approaching he disappears very quickly into the recesses of his den, and only comes out at night.'

'I wish spiders were not such ugly as well as such cruel creatures,' said Claude.

'They are not all ugly; some of our British spiders are, I think, pretty; and out in the Amazon country I was speaking of, near a place called Nazareth, are some beautiful coloured spiders, red, pink, green, \&c.; but I don't know that you will admire their character when I tell you they double themselves up on plants, so as to look like flower-buds, and then pounce on some poor unsuspecting little insect. There is an extraordinary spider out there, called Acrosoma arcuatum, which has two long horn-like appendages to its abdomen. They are very fine and bronzecoloured. The spider makes a large web. By the way, I forgot to tell you there is a Mygale in Martinique which undoubtedly kills birds. It climbs trees for young humming-birds, and throws itself on them, and then tries to put its poison-fangs between the skull and the vertebræ. I believe the effect of this would be to paralyse the bird, so it would not feel pain afterwards.'

\section{'Is that the tiger-spider?'}

'The tiger of the insect world, you mean. No, that is another family; it is a Galeodes, and is found in India; it lives on lizards, crickets and beetles, and preys on birds, though I don't think it eats the birds after it has killed them; it murders them in such a 
cold-blooded way, literally sawing off their heads and legs with its powerful jaws. This spider has even been known to kill musk-rats, but that is due more to the violence of its poison than to its strength, and it does not eat either rats or birds; apparently it kills for the pleasure of killing very often. I have also seen in India, in hollow trees or in holes in banks, a bunch of apparently black horsehair, which bunch is composed of about fifty or sixty or perhaps one hundred small spiders, with very small bodies, and very long, very thin shiny black legs; these rejoice in the name Phalangium bisignatum.'

'I would rather find those than the tiger-spider; I hate those great cruel bird-killers.'

'There is another spider in Ceylon which kills birds; it catches them in its net, and its young family feed on them. This is the Olios taprobanius; its under-surface is a fiery red, the rest of it is covered with short fine hair; its web is so strong that if you come in contact with it in a wood it will actually knock your hat off, and you easily might come in collision with it, for some of the threads are carried, at a good distance from the ground, from tree to tree, in a horizontal direction. These lines are the strongest, and between them the web is spun.'

'Have you told me of all the Mygales now?'

'Oh, dear no! they are much too numerous for that. One of the smallest of the genus found in the West Indies is called Craticus, or the clay-kneader, because 
it makes a nest of clay in the shape of a tube; this tube is six or seven inches long and one inch in diameter; it lines it with a pale orange-coloured drapery, if I may so speak, for this web is scarcely silk, it is more like very fine kid than anything else I can think of. Perhaps we might call this an æsthetic species, as it affects such high-art tapestry for its walls. It makes a door to this house as large as a crown piece, of twelve layers of the web which forms the lining; the outside is concave, the inside convex; the layers are all united at the hinge, which is very thick and strong and about an inch long; it is very elastic and acts like a spring. The door fits so truly that it is almost impossible to find it; outside it looks like the upper valve of a young oyster-shell or like lichens. By the way, I read somewhere the other day of a very clever trick played by a spider, Mygale sauvagesii, on a naturalist in Corsica, who destroyed the door of his nest in which the spider and his family lived. Sauvagesii made another door, but this time he made it without a hinge, so that it was immoveable.'

'How did he go in and out, then?'

'I suppose he remained inside his tunnel till the danger was passed, or cemented it up each time he went in and out; all I know is, he made no hinge. Some foreign spiders make most ingenious nests. If you will bring me that case off the second shelf over there, I will show you one or two. There, this long 
pod, tapering as it does at both ends, is the nest of a spider, the Pensile spider; it is suspended by one end to the branch of a tree. There are generally a bunch of five or six of them to be found together; you see they are made of very soft material, and contain the eggs and the young spiders after they are hatched. Here is another very ingenious one made out of several seed-pods, and fastened together with silken threads, so as to make a sort of hollow ball, which is lined with silk for the accommodation of the young spiders. And now it will soon be time for you to start, if you mean to catch the train.'

About an hour after Martin and Claude had started, Mrs. Martin was sent for, and ordered to tidy the room, and make her master as dapper as circumstances would permit; and by the time Mr. Mygale and his room were arranged to his liking, Mrs. Meadows arrived, having been sent for by the letter written in the small hours. She was closeted for more than an hour with the eccentric little man, who then began to fidget and worry until Claude returned, till Mrs. Martin grew impatient, and begged to be told how she was to cook a dinner, and run in and out of the kitchen to answer the study-bell every five minutes.

'I hope the next time Master Claude goes out you won't send Martin with him, sir.'

'My good woman, I purpose sending Martin and Master Claude a longer journey than to Anntown, I 
can tell you ; at least, I can't tell you anything about it till Master Claude returns,' replied Mr. Mygale.

Master Claude returned as usual in high spirits, and was exceedingly surprised to hear his mother had been to see his host in his absence, and was still more surprised when he learnt the result of her visit.

'Your mother and I have come to the conclusion that you and Martin may be trusted to go to the Cape, and get me the spiders I want; so I have settled to let you both go next week, said Mr. Mygale, as if they were going up to London or to the county town.

Claude could hardly believe it was true.

'Oh, Mr. Mygale! are you teasing me? Do you really, truly mean it?'

'I do, really and truly; I am going to write for your passages to-night.'

'But what will you do without Martin and me? You will only have Mrs. Martin to nurse you.'

'I shall have James and his wife up from the Lodge, and if they can't manage between them to attend to me, I have promised your mother to let her send for a trained nurse. I shall be well looked after, for Mrs. Meadows would only consent to let you go on condition that I allowed her to come every day and see me; but I shall miss my little companion all the same.'

'But you'll get the spiders, and I shall have heaps 
to tell you when I come back. Oh, Mr. Mygale! it is awfully kind of you to let Martin go with me.'

'You shall go as comfortably as possible; I have told your mother that. You'll be gone ten weeks altogether: the voyage out takes twenty-one days; you will want a month to collect the spiders in, and another twenty-one days to come back in. By the time you return, I hope you'll find me ready to dance a break-down in your honour.'

'Does Martin know yet? have you told him?'

'No; but you may go and break it to him, if you like. He will be as delighted as you are; he is always glad to get out of England.'

Martin, as his master foretold, was as pleased as Punch on hearing the news; indeed, it would be hard to say who was the happiest, Claude, or Mr. Mygale, or Martin. There was so much to talk of and arrange that the conversation never once flagged; and, indeed, for the whole of the intervening week nothing was talked of but the proposed trip; and the spider-lessons were given up, and books on the Cape, which Claude read aloud to Mr. Mygale, took their place.

'You have never heard me sing, Claude, have you?' said Mr. Mygale, the evening before Claude was to start, when evcrything having been packed up, and the last label tied on, there was positively nothing left for Claude to do, and he was in consequence very restless.

'No; do you sing?' 
'I used to, in the days of my youth. I'll sing you a song about a spider, and you shall juclge for yourself what you think of my vocal powers. Look in that cupboard, and you'll see a guitar.'

Claude obeyed. Mr. Mygale cleared his throat; and then, in a rich, full tenor, sang the following old song, accompanying himself on his guitar:-

'Spider, spider, what do you spin?

Mainsails for a man-of-war.

Spider, spider, 'tis too thin;

Tell me truly what 'tis for.

Why, good fly, the spider said,

'Tis for curtains for the king,

When he sleeps on his state bed.

Spider, 'tis too slight and thin.

Slight and thin, your eyes deceive,

Said the spider to the fly;

Strong and tight and firm I weave,

Come, examine, touch and try.

Spider, spider, 'twill not do;

Of your arts I am aware:

Men have cautioned me of you,

Told me duly to beware.'

'I believe there is another verse, but I can't remember it,' said Mr. Mygale; and then, before Claude had time to thank him, he burst out into another song, Italian this time, from some opera; and then, as if possessed, he went on, song after song, and though he was reclining, and had difficulty in holding his instrument, Claude felt he was listening to no mean performer; indeed, the rich voice was so powerful 
that it reached the kitchen, and brought Mrs. Martin and Martin out, to listen in the hall, in amazement.

'Lor' a mercy! I hope the master is not dying, like the swans I have heard tell of, which never sing till just before their death,' said Mrs. Martin.

'You need not fear; it is not the first time I have heard the master sing;' said Martin, mysteriously; but more he refused to say; and his obstinacy might have led to a conjugal quarrel, had not the fact that he was leaving home the next day for nearly three months, softened Mrs. Martin's heart.

Mrs. Meadows drove to the station with Claude the next day, and received many parting assurances from Martin that he would take the greatest care of the young master; and in the afternoon she paid her promised visit to Mr. Mygale, who was rather depressed at losing Claude and Martin. 


\section{CHAPTER VIII}

\section{ON THE HIGH SEAS.}

'I hailed thee, friendly spider! who hadst wove Thy mazy net on yonder mouldering raft;

Would that the cleanly housemaid's foot had left Thee tarrying here, nor took thy life away.'

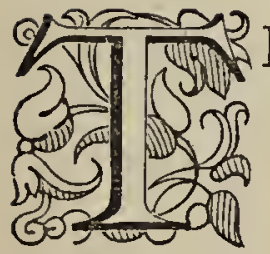

HE first few days of the voyage were not happy ones for Claude; it blew heavily, the ship rocked tremendously, and he was glad to spend the first forty-eight hours in his berth. After this the weather moderated, and he was able to shake off his sea-sickness. He soon made friends with the other passengers; but the captain became his special friend, when the latter discovered the object of Claude's journey to the Cape ; for the captain was a naturalist, and knew a great deal about spiders. He had been all over the world, so he was able to tell Claude about the various countries he had visited, and many were the chats they had on deck and in the captain's cabin.

'Did you find any new spiders there?' was the $\mathrm{K} 2$ 
question Claude always asked, when the captain mentioned any new country, and the answer was generally in the affirmative.

'If I had been Mr. Mygale:' said the captain one day, 'I should have sent you either to Brazil or to the West Indies, instead of to Africa; not but what you will be very likely to get some good species at the Cape, if you go up country; but you won't find such monsters as you would in Brazil, or Ceylon, or the West Indies. The African Mygales, of which there are four species at the Cape, are much smaller than the South A merican or West Indian Mygales. The largest African Mygale (funebra) is only a little over an inch long in the body, while, as you know, the Bird Mygale (avicularia) is two inches; the Mygale fasciata of Ceylon and Asia is two and a-half inches, and Mygale maculata of South America is the same size.'

'How many species of Mygale are there altogether' in the world? do you know?' asked Claude.

'Baron Walckenaër mentions thirty-six.'

'Thirty-six species! why, I thought there were only about six! Are any of the others as large as fasciata and maculata?'

'One, named Blondii, after a Dr. Le Blond, who found it at Cayenne, is the same size; it is found in Brazil, and in the West Indies also; it is reddish brown in colour, and the monster makes a cocoon as big as a pigeon's egg. It lives in holes in the ground, but it also hides itself under stones or in rotten wood, and 
has an agreeable habit of paying nocturnal visits to travellers in their beds. It makes no web, but feeds on bees, wasps, ants, and other insects; in the morning and evening it goes on hunting expeditions, climbs trees, intrudes its disgusting body into the nests of colibris and other birds, and sucks their eggs, or the blood of their young.'

'I am rather glad Blondii does not live at the Cape; I should not care to find him in my bed at all. Are all the Mygales disgusting-looking ?' said Claude.

'Most of them are, I think ; but there is one exception I know of, a rose-coloured species, called Mygale rosea, which is found in Chili and other parts of South America. There is another species found in Brazil, called ochracea, which is not so ugly. Its legs and abdomen are pale pink, its breast-plate brown; but the abdomen is covered with red hairs, which gives it a repulsive look. The bird-spider is a horriblelooking creature, but its web is always clean, and its cell is beautiful, made of pure white silk in the shape of a tube; its cocoon has three silken coverings, and is placed near the cell, where the mother watches over it, but, nevertheless, it often falls a prey to the red ants, which eat the eggs and the young spiders. One of the strongest Mygales is murina; this is a monstcr, two inches long; it has very thick front legs, but I don't know what country it is to be found in. Then there is the Zebra Mygale, which might be called handsome; its body is black, striped with 
orange-red, like a zebra's. The Australian Mygale is remarkable for its long legs.'

'Would you mind describing the four African species to me? then I shall know them if I am lucky enough to come across them.'

'You certainly ought to come across them, for three of them are to be found near the Cape, sometimes in the roofs of houses, and on the walls you may see them. Let me see, there is villosa, a hairy creature, its body less than an inch long. It has orange-yellow eyes, and a little tuft of hair on the tubercle on which they are placed. Then there is the Caffer Mygale, nearly an inch long; the females are bright red in colour, the males grey; there are two varieties of this species, one smaller than the other. Mygale funebra is larger; it is more than an inch long, dingy in colour, and covered with fur or hair. The fourth species, cellicola, is 'common about Alexandria, but I am not so sure that you will meet with it at the Cape. It is one of the smallest Mygales; the body is less than half-an-inch long; the breast-plate is grey, the abdomen an ashy red, with a brown band across it; the legs are strong, the fourth pair the longest ; it is one of the tunnelling spiders.'

'All the Mygales are tunnel-makers, aren't they?'

' Oh, no! some are content, like fasciata, to shut themselves up in the holes of trees or rocks, or in cells or plants. By the way, there is yet another species of Mygale you may meet with at the Cape, called 
Mygale Barrow, from a traveller named Barrow, who first found it in South Africa; he teils us that some of the native tribes mix the blood of this spider with the juice of the amaryllis bulb, to poison their arrows. This is an underground spider, and makes a door to her tunnel of earth and manure bound together with her threads; the door turns on a hinge, and the owner may be found close to it, holding it ajar, on the watch for prey, and ready to spring out on any victim; but if she scents any danger she promptly closes the door, and waits for a few minutes, and then opens it carefully again, to see if her enemy has retired. I forgot to tell you of a rather handsome Mygale I have seen at Martinique and Guaduloupe; it is nearly two inches long; the breast-plate is large, and like black velvet, with a beautiful green metallic hue on it; the abdomen is oval, covered with a down like black velvet, on which grow red hairs, which, in a certain light, have a violet tinge; this species is called versicolor. The black Mygale, found in South America, is two inches long, and very like the bird-spider; it has reddish brown hairs on its great jet-black body. A still larger Mygale is hostilis; rather over two inches and a-half long, it has short legs, and the body is reddish brown, but I don't know what country is its home; if you should come across it in South Africa you will easily recognise it by its short legs, for which it is remarkable. The principal characteristic of the Australian Mygale is the respective length of 
its legs ; the third pair are the shortest, the fourth the longest; its body is an inch long, the legs and breastplate reddish brown, the abdomen greenish brown. The New Zealand species is larger, and pale red in colour, with black and brown markings. And now, I think, I have told you all I know of the Mygales, except those you have heard all about from your friend, Mr. Mygale. By the way, what an odd name for a man!'

'Yes, it is: I sometimes think there is some mistake about it; I don't quite believe it is his real name. Must you go now, captain?'

'I must, indeed; but we will have another talk tomorrow, if you are well enough. It is going to blow half-a-gale to-night.'

'Oh! I am a first-rate sailor now,' said Claude; but, nevertheless, he felt very squeamish when he rose the next morning, after a lively night, and was glad to let Martin officiate as his valet.

The captain, true to his promise, was ready that evening to have another talk with his little friend, who, as the ship still rolled, was obliged to lie on the deck, where he declared he felt all right.

'I want you to tell me about the Tarentulas, captain, to-day, please.'

'Well, there is more nonsense talked about them than about any spider, but my own belief is there is some truth in the nonsense; at least, there is no doubt that the true Tarentula has a very venomous 
bite, but many other species far less venomous have been confounded with it, and as for the stories of the victims dancing, and being affected by certain colours, numerous as they are, I don't think they can be authenticated.'

'Which is the true Tarentula?'

'The Apuleian species, found in the South of Europe, and particularly near Naples and Tarentum. Its real name is Lycosa tarentula apulice; for all the so-called Tarentulas are wolf-spiders, as you know; they hunt their prey, carry their cocoons suspended by threads to their bodies, and their little ones, when hatched, upon their backs. No spiders have been so confused as the Tarentulas; but, according to Walckenaër, who I consider to be the best authority, there are five Tarentulas, six Tarentuloides, and five Tarentulinas. The Tarentulas are large spiders, an inch or more long; they all hide in holes in the earth or under stones and trees. The true Tarentula is a little over an inch long, and, though many other species are so often confounded with it, may be easily recognised; it is an ashy grey colour, with black triangular spots on the back; the under surface of the abdomen is a reddishyellow, with a black transverse band toothed at the sides; the legs are grey, with large white bands. This spider, so celebrated for its poisonous bitc, makes a hole in the earth in sunny spots on a gentle slope in uncultivated places; in the middle of the day the opening to this abode is occasionally exposed; 
but, as a rule, it is very strongly fortified with dry plants, which the spider glues together and to the ground with her threads; this fortification protects the house from rain or falling dust or stones.'

'Is this the only European Tarentula?'

'No, there are three other European species; the French Tarentula, which is found in various parts of Europe, and is called Narbonensis; it is rather less than an inch long; the back is pale brown, with black zigzag marks and triangles. Then there is the Greek Tarentula, called Hellenica, very like the French species, only larger; and the Spanish Tarentula, about the same size as Narbonensis. Strange to say, though the Greek peasants are very much afraid of insects, they are not at all afraid of the Tarentula. Both the French and the Greek species make holes in the ground, and wait at the entrance of them, still and immovable, till some victim passes their door, when they pounce out and drag in their prey as quickly as possible; they are exceedingly rapid in all their movements, and a French naturalist describes them as jumping away as if moved by electricity if you attempt to catch them. The French Tarentula fortifies its hole, like the true Tarentula, and the female lives in it with her young; but as the males are always found in separate holes, I suppose that, like most spiders, they do not live together. It is very difficult to get these Tarentulas out of their holes when they have their cocoons, for they stiffen themselves against whatever you thrust 
in to seize them. The greatest enemy of the French Tarentuld is a large scolopender, five inches long, which attacks them, and very quickly takes possession of their houses; but rain destroys their divellings even more than the scolopenders, cleverly as they make them.'

'What is a scolopender, captain?'

"Well, it is not an insect any more than a spider; it is a very venomous creature, with a long slender body and a great many feet; it runs very fast, and generally lives in the bark of decayed trees, or under logs; it hates the light; its nearest relative is the centipede. But I have two more real Tarentulas to tell you about, both of which are found in North America; they are rather more than an inch long. The Caroline species is very like the French Tarentula, but larger; it is more than an inch long; it is reddish brown, the under surface like black velvet. The Georgian Tarentula is the same size, and indeed very like the Carolina, but is distinguished by a dozen round white spots in two lines down its back; it is a rare species.'

'Shall I find a Tarentula at the Cape?'

'Not a true Tarentula, but the Madeira Tarentuloides is found in some parts of Africa; it is a large spider, its body fully an inch long; fawn-coloured, with brown spots and red legs. Then there is a Russian Tarentuloides, whose body is little less than an inch long; the Russian children play with these spiders, and often get severely bitten, though the bite produces none of 
the ill effects attributed to the real Tarentula. There is a species of sheep in Russia very fond of these Tarentulas, and as in that part of the country the peasants are very much afraid of them, they will not pitch their tents where they are found. These sheep are very much prized; if they are bitten, they cure the bite by smashing the Tarentula in olive oil and putting it on to the wound. Most of the Tarentulas are nocturnal in their habits, hunting all night in the neighbourhood of their holes, but remaining hidden in them during the day. The true Tarentulas, and I believe many of the others, retire for the whole of the winter into their holes, which they stuff up with dried leaves, straws, and their own silk so thoroughly that no rain or snow can possibly get to them. They then fall into a state of stupor, which lasts till the spring; they can subsist for a long time without food. Of course, like all hybernating animals, there is no difficulty about this during their torpid state; but naturalists have kept them alive for six weeks and two months without food. These spiders do not attain their full size till after they are two years old.'

'The Mygales and the Tarentulas are the largest of all spiders, aren't they, captain?'

'Yes; but there is another genus of large spiders often confounded with the Mygales, on account of their large size and dingy colours, called Olios.'

'I don't think I have ever heard of them,' said Claude. 
'There is no British species, and only one European, so perhaps that is why Mr. Mygale never mentioned the genus; they vary in size, but their average length is about an inch; their eight eyes are in two parallel lines; they have long strong legs of almost equal length; they spin some very strong threads, and they have the power of running in an inverted position; they are very bold creatures, and attack large insects, and even little lizards and small birds. At least small birds have been found in the web of Olios taprobanius, the Ceylon species, the largest of all. These spiders are mostly found in the islands of the Pacific and of the Indian Ocean. Walckenaër describes fifteen species; they are often confounded with the Mygales on account of their large size, their long legs, and dingy colours.'

'Are there no African species?'

'Yes, there is one found at the Cape, which you may come across; its other name is provocator; it is not a large species, rather over half-an-inch long; the breast-plate is heart-shaped, covered with grey hairs, the abdomen oval, and also covered with hair. There is a long-legged species found in the Moluccas which is a monster; its body is the same size as the Ceylon species, and its legs between three and four inches long; longipes is its name. There is a South American species, a trifle smaller, called leucosius.'

'I wonder if you know of any other genera which I have never heard of ?' asked Claude. 
'Did you ever hear of the genus Sphodros?'

'No.'

'Oh! well, they are very interesting spiders, first cousins to the Mygales. They are hunting and tunnelling spiders, but they line their tunnels with white silk, of which half hangs out of the earth like a silken bag, or rather purse; indeed, they are sometimes called the "Purse-web Spiders." Their legs are short and thick. The species called Abbotii, after a Mr. Abbot, who has written a book on the spiders of Georgia, is two inches long, inciuding the mandibles, but the body of the male only measures one inch; he is smaller than his wife. This spider makes its tunnel and purse-like web in swampy ground, at the root of large trees. The purse is a foot long; half of it is embedded in the earth lining the tunnel, the other half hangs outside, and is generally attached to the trunk of the tree. The spider lives at the bottom of its hole, where it may always be found during the day, for it is nocturnal in its habits. Its little ones cover the back of the mother when they are first hatched. This species is found in Brazil and Georgia. There are only two other species: a small one, not more than half-an-inch long, found in North America; the other is found only in South America. The male is much smaller than the female; she is an inch long. They are bluish-black in colour. Then there is another genus, called Missulena, which has only one species, found in New Holland. This is a monster. 
Its body is an inch long; it has short, swollen legs, and is brown in colour. It makes a circular hole in the earth five or six inches deep, and closes it with a door; but, strange to say, the door is always open when the spider is at home; so I suppose it is an hospitable creature. Did you ever hear of the genus Filistata?'

'No;-why, I believe you know more about spiders than Mr. Mygale, captain!'

'Trust Mr. Mygale; he knows all these spiders well enough. Filistata has only one species that I know of, but as that is European-not British, though-I thought he might have mentioned it. It makes a silk bag under a stone, and goes out on hunting expeditions. It is about three-quarters of an inch long, and is found in Spain and the South of Europe. There is another genus I don't suppose you have heard of, called Selenops; it contains six species, and, as three of those are African, I may as well describe them. One of their chief characteristics is-they run very quickly, with their legs spread out sideways. Their legs are long and strong. The largest species is found in Brazil, and is rather over half-an-inch long; it is black. The three Africans are exactly half-an-inch, and you will probably recognise them by their flat breast-plates. The European species, found in Spain, is smaller.'

'Do you think any one ever ate a spider, captain?' asked Claude. 
'Oh, yes; some savages eat them. There is a species of Epëira, called edulis, in New Caledonia, which is considered a great delicacy. The legs and breastplate are taken off, and the abdomen is rubbed over with butter, grilled, and eaten; but, you know, we all eat plenty of small spiders unconsciously in fruit and vegetables. But the greatest enemies of spiders are monkeys, lizards, frogs, toads, birds, squirrels, and those Russian black sheep I told you of. In the East Indies there is a species of sparrow whose sole food is spiders; then the scolopenders are, perhaps, their bitterest foes; wasps and mason-flies also destroy many spiders. The mason-fly is particularly cruel in her attacks; she constructs her nest, and lays an egg in it; then she fills the nest up with spiders, and fastens the entrance securely up. In due course the larvae come out of the egg, and eat up the spiders; these are generally some of the Thomisus genus. And here I must stop for to-day; said the captain; who, to do him justice, seemed capable of going on talking of spiders, without tiring, by the hour.

Claude found the time hang rather heavily on his hands during the voyage, so he was always ready to listen to the captain's stories, and seized the next opportunity to ask him for more spiderlore.

'Well, there is a strange genus of spiders, called Clotho, all four species of which are found in Africa, so you will take a great interest in them. They make 
nests for themselves under stones and behind a web, and here they live with their little ones. The most celebrated Clotho is named Durandii, after a French naturalist. It is not quite half-an-inch long, and is found in Europe and Africa. It makes a most remarkable nest-a kind of tent, in the shape of a cup. The roof is an inch in diameter, and is placed on the under surface of a stone, to which it is attached by seven or eight threads. The texture of this tent is like the finest muslin, but its thickness depends on the age of the spider, which spins a fresh lining every time it moults. When the spider intends to have a family, she makes another apartment especially for her cocoons. This second cell is of softer and more downy silk than the outer tent, and, though that may be dirty, accidentally or purposely to conceal it, the nursery is always scrupulously clean. This spider makes five or six cocoons, white as snow, which are placed in this inner cell, and carefully enclosed in down. The entrance to this apartment is very intricate, and known only to the mother. The little spiders live here till they are old enough to shift for themselves, and then they depart, and leave the mother to die in her tent. This spider is afraid of heat, and does not like much light. When she sees a fly pass over her web, she goes out, seizes it, and swathes it in a shroud, which she spins as fast as she can. The other three species are smaller, and, as far as I know, do not make so elaborate a house.' 
'Where did you learn all this, captain ?'

'I learnt that, and most of my spider knowledge, from Baron Walckenaër's splendid books on spiders. Very nearly related to Clotho is the genus Latrodecte, included by some writers among the Theridions.'

'Oh! I have heard of them-the Theridions, I mean.'

'Well, the Latrodectes resemble the Theridions very much; but they differ in the arrangement of their eyes, and, as you know, spiders are classified chiefly by the number and place of their eyes. The sideeyes of the Latrodectes are rather wide apart, and on prominences. These spiders spin webs under stones and in paths so knotted and strong that the largest insects are caught in them. The most remarkable species is malmignatus. It is reported to be very venomous, and its bite is said to cause fever to human beings; in fact, it is reported to be dangerous in Corsica, and the effects resemble those produced by the bite of a viper ; but I don't believe these reports. In the first place, its mandibles are not very strong, and the spider is only half-an-inch in length. Probably it is true that its bite is very poisonous, for the American species are also noted for the same thing. Its web is very strong, and catches locusts and other large insects, on which this little spider, though not at all brave away from her web, pounces, and she kills and eats her prey after she has seized it. The malmignatus are not amiable spiders; they kill and 
eat each other, and fight furiously. They make four or five cocoons, pear-shaped and pointed, écru or deep cream-coloured, and about the size of a hazelnut. These are suspended to the roof of a fairy cave, hollowed out of a sloping piece of ground. The outer skin is as thick as cardboard, and Baron Walckenaër tells us he was obliged to use his penknife to open one. He found over two hundred eggs in all, strung together like a string of fairy pearls on imperceptible thread. The mother takes the greatest care of these precious cocoons, and not only watches by them, but after she has finished laying she ceases to eat, and dies before the winter, though the little spiders are not hatched till the following spring.'

'Is this a very rare spider?'

' On the contrary, it is common in Corsica, Sardinia, and parts of Italy. It is a pretty spiderblack, with a blood-red band and blood-red spots. The North American species, formidabilis, is larger, and is rare.'

'Is there an African spider of this genus?'

'Yes, there are three, but all found in Egypt; two are very small, and the third, Erebus, is rare. This species is, I need hardly tell you, deep black. It is a trifle larger than malmignatus, and makes a similar cocoon. It spins a snare under a stone, in which it lives, and counterfeits death if surprised. The three African species are all about the same size-that is, about half-an-inch long, and are all noted for their 
venomous bite. Variolus is very pretty--black, with bars and spots of crimson and white.'

'What numbers of spiders there are-of different kinds, I mean! I thought Mr. Mygale had told me about nearly all the kinds, but you have told me of many he never mentioned.'

' Because he confined himself a great deal to British species. But I have been thinking of the best plan for you when you get to Cape Town, and my advice is to stay there a day or two, and then go by boat to Knysna, a beautiful place, two hundred and fifty miles to the east of Cape Town. It is very healthy. The scenery is charming, for you get every variety,- -there is the sea, the forest, and the mountains; and you could make excursions into the country, where you would meet with more spiders than near Cape Town. The African Mygale, I know, is to be found at Knysna, and there is a terrible pest there in the shape of a tick, which you won't care to add to your collection.'

'Oh! we'll go to Knysna, if Martin agrees. I am so glad I am coming home by this ship, because if I don't know the names of the spiders we find, you'll be able to tell me, won't you, captain?'

'Yes, with pleasure. Our talks are nearly over for the present, for we are due at Cape Town the day after to-morrow.'

This was such good news for Claude, who, in spite of his liking for the captain, did not enjoy life on 
board ship, that he jumped up and ran to communicate it to some of the other passengers. And in the anticipation of sighting Table Mountain, and the excitement of arriving, all thought of spiders slipped from his mind. 


\section{CHAPTER IX.}

FOREIGN SPIDERS.

'There lives and works

A soul in all things; and that soul is GoD.'

HE ominous white cloud known as the Table-cloth hung over Table Mountain when Claude's ship steamed into the harbour, and the south-easter, of which it is the herald, followed in due course; and as Claude was such a bad sailor Martin decided to miss the first boat to Knysna, which started a day or two after their arrival, and wait till the following week. Meanwhile they saw the lions of Cape Town, and made excursions into the country, during which they employed themselves in spider-hunting, the main object of their visit. But when they did reach Knysna they were so enchanted with its beauty that they almost grudged the week they had spent in the city, in spite of the spiders they had captured.

The forest with its baboon-ropes of gorgeous creepers hanging from the trees, and the priceless orchids which threw their strangely beautiful blossoms in lavish profusion over the undergrowth 
or among the lower branches, drove Martin to despair, because, as he said, they would have made his fortune if he could have conveyed a quarter of them home to England. This was Claude's special delight, and here he found plenty of spiders. Here too he found many strange beetles, and regretted that he knew nothing about them. Occasionally they came upon a puff-adder, but Martin was too careful to run any risks of being bitten by these poisonous reptiles. Once they made a long excursion, and spent the night with a Boer, a farmer who made them as comfortable as his homely means would allow. The next morning they returned to Knysna, where they remained till a few days before their ship sailed.

Claude was glad to see his friend the captain again, and as the weather was calm and delightful, he enjoyed the homeward voyage. Nearly every day he spent an hour or two in the captain's cabin, exhibiting his spiders, identifying and labelling them, and picking up a good deal of information about them.

'You have some Epëiras here, I see; this is Imperialis, and here is an Aurelia.'

'That last big one was given me; it comes from the North of Africa.'

'I thought so; it is a very interesting species. It hangs its cocoon up by threads fastened to its edges, so that it looks like a fairy lamp suspended in the air ; the threads are very strong, and the shell of the 
cocoon is like parchment, and difficult to tear; but the young spiders as soon as they are hatched make their way out of the little door or lid which closes it, and roam about, going back to the cocoon when they are tired. They live here happily till they are large enough to shift for themselves, when they become deadly enemies. The mother lives in her web, which only catches very large insects, wasps and large flies, and occasionally locusts. I have a very large Epëira, over an inch long, in my collection, which I found in North America; it is nearly an inch broad also, and is called jaspidata. 'It is one of the very largest Epëiras, sometimes called the Giant Epëira. It makes a large web in oak-forests, generally between two trees. It is round and vertical. The spider makes a retreat for herself with some leaves close by, and remains there, head downwards, watching her web for any insects that may be caught in it. There is another equally large Epëir a found in Brazil, and one, a trifle bigger, called fuscipes, remarkable for its very long legs, found in China and the East Indies.'

'Is not there a yellow Epëira?'

'Yes, called clavipes, found in Jamaica, Brazil, San Domingo and Cayenne, where it is very common, but it has never been found farther north. It is a golden-yellow with silver spots, nearly an inch long, and is very handsome. It makes a large circular and spiral web of yellow silk, so gummy that even wild pigeons have been caught in it. Small birds are con- 
stantly caught in it, and even a man, if caught in it, would have to release himself from the strong sticky threads; it is often spread between trees three or four yards apart. This is the spider whose silk was once used for gloves in France. The largest of all the Epeiras is chry'sogaster, found in the East Indies. It is nearly two inches long; the breast-plate is a metallic gold, the abdomen very long, with a gold stripe down the centre; the legs are very long, black and thorny. But what have we here?' said the captain, taking up a small but very tough and thorny spider.

'I believe it is an Epïira,' said Claude.

'Oh no, it is not. I can tell by its tough, rough, thorny body, it is a Plectane; a large genus of seventy or eighty species, that I daresay you have not heard of, for they are only found in warm countries. You may easily recognise them by their hard shell or skin; they are generally found, like the Epëiras, in their webs, which are circles crossed by straight rays. Your species is Mauricia; her web is generally suspended across the paths in woods. She lives close by it; if touched, she folds her legs up under her body and drops to the ground on a thread. The Plectanes are little spiders, the abdomen often broader than it is long; in some species it is triangular and armed with very long thorns; in other species the abdomen terminates in two lobes armed with spines, so that the creature looks something like 
a short earwig. They are not a particularly interesting genus, but I am glad you have found some.'

'Now I have a puzzler for you, I am sure, captain. What is this little bright yellow creature, something like an Epëira, only I believe its eyes are differently placed?'

'Quite right; I was going to say it would be an Epeirra if they were not, but that is rather a bull. It is the yellow Teloborus flavus; there are only five species, so you are lucky to have found one.'

'I wonder how many more genera there are that I have never heard of ?'

'Only one; and you may have heard of that, the Argus. They are very small spiders, brown or red, and they make very little webs on plants, or rocks, or over holes in the ground, and hide under stones or moss. When the time comes for them to make their cocoons, they find a deserted web of some other spider and there deposit them. I see you have found the longlegged species.'

'I don't much care for such tiny little spiders; but I know Mr. Mygale likes them, so I caught those I could.'

'Some of the Arguses are not easy to catch ; formivorous, or the ant-eating Argus, is an exception. She counterfeits death, and is slow in her movements; if on her cocoon, she does not stir.'

'She must be a big spider if she eats ants.'

'No; indeed she is scarcely larger than your longipes, that is, about one-eighth of an inch long; nevertheless, 
she makes great havoc among ants in this way. She cncloses her own eggs in a round cocoon of a loosely woven silk; she then surrounds this cocoon with another envelope of still more loosely woven silk, and in this she puts a quantity of chrysalids of ants, on which, as soon as her young spiders are hatched, they feed; she makes a little irregular web, and is found under stones in most European countries. Some of the Arguses make so tiny a web that they are only observable when covered with dew. Oh! here is an Epëira conica, a European species. I didn't know it was found in Africa; it makes a web of the same kind as the other Epëiras, but of very fine network, and leaves one space in the circle unfilled up; in the centre of the web she lives, not in an inverted position like the other Epëiras, but lying sideways, with her head on her web. By the way, there is an Epëirc nearly related to conica found in South America, Europe, and Asia, which has a very peculiar way of defending itself if disturbed in its web, in the centre of which it is usually to be found; it shakes the web so violently that its own body becomes almost invisible; sometimes it suddenly drops down to the ground, if there is any cover for it, but always taking the precaution of descending on a thread. This species, if it catches a wasp or any other insect in its web, immediately twists the victim round, and at the same time spins threads all round its body, swathing it as in a shroud; then it examines the helpless victim, finds a 
suitable place and bites it, and then waits until the poison has killed it.'

'Do spiders ever live in flocks, captain ?'

'Are they gregarious? you mean. Undoubtedly some are; in Brazil and Paraguay Mr. Darwin and Azara both found some Epëiras, and I believe some Theridions also, living in flocks, for Mr. Darwin found a quantity of Epëiras' webs, separated by about two feet from each other, over large bushes in South America ; and Azara says he has seen a nest as large as a hat, in which all the eggs of a community of spiders were laid; this was in Paraguay; and my authority for saying these spiders were probably Theridions is Baron Walckenaër.'

'Are there no foreign water-spiders, captain?'

'There is only one species of Argyroneta that I know of, and that is aquatica; found in most European countries, but I really don't know whether it has been noticed abroad. There are two or three Epäiras in my collection that I should like to show you; Epëira inaurata, or the golden Epëira, for instance; it is a very handsome spider, over an inch long; the abdomen is a brilliant golden yellow, the breast-plate brown and silver; the legs are very long, over two inches; this is found on the shores of the Indian Ocean. Then there is the Epeira opuntia, found in both Europe and Asia on the Cactus opuntia. This spider lives in the society of its own species, numbers of it being found at the foot of the same plant; it dislikes cold very 
much, and is found in the middle of its web with its legs spread out, waiting for victims; when the wind is high or the weather bad, it hides itself among the thorns of the cactus, where the threads of its web make a little shelter. The cocoons, which are small and white, are often found strung together, as many as ten on one thread sometimes; but whether they are the work of one spider or of ten is more than I can tell you. The species calloplyylla is European, but peculiar in its habits; it makes a small web of very fine threads inside houses, often among shutters or on window-frames; at the top of the web is a little silken tube where the spider lives during the day, at night she is to be found in the centre of her web; this tube is connected with the web by one very strong double thread, on which the spider ascends and descends when a victim is taken in her toils. If the victim is a fly, this spider garrotes it, then bites it and stupefies without killing it; she then fastens it to her spinnerets, carries it to her tube and eats it at her leisure, using the connecting thread as a road. Though less than half-an-inch long, she can carry large meat-flies by this means. The species tubulosa resembles callophylla in its habits, but is smaller.'

'Have you any big Epëiras besides those you have told me of ?'

'I have a geniculata, which is one and a-quarter inch long; it is yellow and black, with tubercles on the back; the legs are very long and strong. I found 
my specimen in Cayenne, but I don't know where else it is to be found. I think I have described to you all the large Epëiras I know of.'

'Do all spiders make cocoons for their eggs?'

'I think all do except the Pholcus, which glues its eggs into a round mass. A collection of cocoons would be very interesting, for they are often very beautiful, and vary much in shape and colour too, though white or yellow is the usual colour. I know of one green cocoon, that of Sparassus verdissime, a green spider; and of one blue one made by Tetragnatha extensa; and Theridion sisyphum makes a reddish cocoon, and some of the Epëiras make cocoons of various colours.'

'I wish I had found some more cocoons; I only got two or three.'

'But you have made a capital collection of spiders ; if this calm weather lasts, we will have them all labelled before you leave the ship.'

This process of identifying and labelling served to wile away many a weary hour on board ship, and was accomplished before they reached England. The homeward voyage was calmer than the outward; but, though sorry to part with the captain, Claude was wild with excitement, when they sighted the white chalk cliffs of England, at the prospect of seeing his mother and the children and Mr. Mygale again so soon.

But, alas! things never turn out as we expect ; and, as it happened, Claude was never destined to see Mr. Mygale again. 


\section{CHAPTER X.}

SIR RICHARD SUTTON.

'More subtle web Arachne cannot spin,

Nor the fine nets which oft we woven see

Of scorched dew, do not in th' air more lightly flee.'

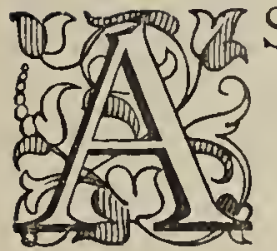

Mr. Mygale's last letter to Claude gave him instructions to go straight home on arriving in England, and if he were not too tired with the journey to pay him a visit in the evening, Claude jumped into his mother's pony-carriage, which met him at the station, and sent a message by Martin that he would run over to Sutton Park after tea. But after the first excitement of meeting was over, Claude learnt that he and Mrs. Meadows were to dine at the park that evening:

'Mr. Mygale and I are great friends now; I have been to see him every day since you left. You must be prepared to find him altered in some ways during your absence, but for the better, I hope; he can get about now on crutches, and hopes soon to discard them,' said Mrs. Meadows.

Claude was rather surprised to find Mrs. Meadows was careful that he should put on his best suit of 
clothes, and came down herself in full dinner-toilette; his surprise increased when a carriage and pair, with a coachman and footman in livery on the box, drove up to the door to fetch them.

'Why, mother, what a grand carriage! whose is it?'

'Sir Richard Sutton's, dear; I forgot you didn't know; he has come back, and is living at the Park now. Have you brought your spiders for Mr. Mygale?'

'Yes. But, mother, who is Sir Richard Sutton? I thought the last baronet had no children,' said Claude, wondering greatly, as they drove off.

'It appears his brother left a son, who has turned up, and put in his claim to the title and the property.'

'But Mr. Mygale bought the place. Surely Sir Richard can't turn him out?' said Claude, indignantly.

'Perhaps it won't be necessary, dear' perhaps the house will be large enough for both of them.'

'I hope Sir Richard is a nice man. I am rather sorry he is there; I have been reckoning so on having this evening all alone with Mr. Mygale,' said Claude, as the Lodge gates were flung wide open, and the carriage dashed past, before he had time to speak to his old friend the lodge-keeper.

'I don't think you will find Sir Richard in the way, dear,' said Mrs. Meadows, with a smile Claude failed to understand.

They drove up to the front door, where another footman and Martin were standing to receive them; they threw open the double doors in the orthodox 
fashion, and Martin said gravely to Mrs. Meadows, as he led the way to the large drawing-room:-

'Sir Richard is in the drawing-room, madam.'

'But where is Mr. Mygale, Martin? I am longing to see him,' said Claude, who could not understand all this state, and was half-inclined to break away from the solemn procession, and make a dash into the study, where he expected his old friend was to be found.

However, he restrained his impatience, and followed his mother into the drawing-room, as Martin announced 'Mrs. Meadows and Master Claude Meadows' in stentorian tones.

The room contained but one inmate, Mr. Mygale, who hastened on his crutches towards his guests, and Claude shook his old friend's hand nearly off in his delight at seeing him again.

'Well, my boy, welcome to Sutton Park! The weeks have seemed months without you, though, you see, thanks to your mother, as much as to any one, I have got on in your absence, and can hobble about on crutches.'

'You look quite well; better than you ever did, I think; but where is Sir Richard Sutton?' asked Claude.

'Here he is,' said Mr. Mygale, in his old, caustic style.

'Where?' said Claude, looking round the room in amazement. 
'Here; I am Sir Richard Sutton,' said Mr. Mygale.

'You are Sir Richard Sutton! Are you teasing me, or is it really true? Aren't you Mr. Mygale?'

'To you I am whatever or whocver you choose to call me,' said Mr. Mygale, regardless of grammar; 'but to the rest of the world I mean to be known by my proper title henceforth. Your mother has persuaded me that it is my duty to live up to the position in which it has pleased God to place me, and not hide my light under a bushel any longer; so you will see there has been quite a revolution here. All the rooms are thrown open; I have hired, or rather your mother did that for me, a staff of servants; Martin is promoted to butler, Mrs. Martin to housekeeper; and as there would not be work enough for all these servants if I were to live here alone in my glory, I must make some new friends and hunt up some old ones to come and stay with me. There is one room, your old room, next to mine, which is set apart expressly for you, my boy; and no matter how full the house may be, that will never be occupied except by yourself. There is the gong for dinner; we won't discuss the subject before the servants, but another time you shall hear the end of the story. I suppose it would be too selfish of me to ask your mother to leave you here for the night, would it, Mrs. Meadows?'

'No, Sir Richard; I was prepared for that. I will lend him to you for a day or two,' said Mrs. Meadows, with a smile. 
Though a small, they were a very happy party at dinner, Claude regaling his elders with an account of his travels.

Claude wanted to spend the rest of the evening in the study, where he had left his precious African spiders; but Sir Richard suggested they should leave the spiders till the next day, and have some music. And then Sir Richard went to the grand piano in the drawing-room, at Mrs. Meadows' request, and sang, accompanying himself in a masterly manner, to Claude's delight and surprise.

There was yet another surprise in store for him before he went to bed, for after Mrs. Meadows had left, all the servants filed in to prayers, which Sir Richard read.

'Why did you call yourself Mr. Mygale?' asked Claude, as the oddly-assorted pair went up to bed.

'Well, I had a foolish idea that people might remember the circumstances under which my poor father left Sutton years ago, and would perhaps give me the cold shoulder; so I resolved not to take my title, but to live here incognito under the name of Mygale, which my friends the spiders suggested; and, lest any one should ferret out who I was, I shut myself up here like a hermit or a miser until you came. And then your mother came to see me every day while you were away, and she convinced me of many things; among others, of the fact that I was 
like the man in the parable, who hid his talent in a napkin; for, as your mother very justly observed, when I told her who I was, riches and rank are both talents, and intended to be used for the glory of God, like every other good thing He gives us. So as soon as I was convinced of the error of my ways, I resolved to amend them. I daresay many people would say the amending was a very pleasant affair, but, as far as my own taste is concerned, I should infinitely prefer to live in the study with my spiders; however, the whole place would go to rack and ruin by degrees if I did, and that would not be fair to my successors.'

'But you have not any relatives to succeed you, have you?'

'In the baronetage, no; the title will die with me, unless I were to marry, and have a son. But though I have done a great many foolish things in my life, I never mean to do anything so silly as that. The property goes to whom I choose to leave it, so I made my will the other day. And now you know most of my secrets, suppose you tell me what that secret promise was you made your mother when you first came here, will you?'

'I am afraid you won't like it, if I tell you,' said Claude, hesitating.

'Never mind whether I like it or not; I wish to hear it, if you don't mind telling me.'

'Well, mother and I had heard a good deal about you, and that you never went to church, and never 
let any one come near the house, because people said you hated every one; so we guessed you could not be very happy, and mother knew the reason was very likely that you didn't love God, because He always makes the people who love Him happy. I don't mean they never have troubles, because mother says they very often have more than other people; but, all the same, they are happy.'

'Well, go on; what was the secret? Were you to try and teach me to love God?'

'Oh, no! I am only a little boy; I could not do that. But my secret was, I was to ask God very often to make you love Him, and, of course, I had to try to be very good myself, because $\mathrm{He}$ does not listen to naughty boys-at least, not as $\mathrm{He}$ does when we are good.'

'Umph! that was your secret, was it? Well, I have a secret too, but I mean to keep mine till I die. When I am dead and gone you will know it, if you are alive, not before.'

And Sir Richard kept his word and his secret during the twenty years he lived after this; and after his funeral, Claude, who was then an officer, home on leave, found his old friend had left him Sutton Park and a very nice fortune, and a clause in the will stated that the late baronet dated all his happiness from the day when he first caught a little golden-haired, angel-faced boy near his trap-door,-a boy whom he had grown to love as a son, and who had indeed been 
a son to him, and lightened the darkness of a lonely life.

Why that life had been for years so lonely,-why Sir Richard had never married,-was a secret that was never known, except perhaps to Martin, who was once heard to say there was a woman at the bottom of it; but beyond this he kept his master's counsel, though he survived him several years, and often entertained the servants with anecdotes of Captain Meadows in his youth, and particularly during the three months he had the honour of taking care of him on the voyage to and from the Cape.

'They are a contrast, if ever there was one, poor Sir Richard and the captain. They were alike in one thing, though, and a queer thing that is; they are both mad on one point, and that point isspiders.'

'And cobwebs; don't forget the cobwebs, Martin,' put in Mrs. Martin. 'The captain is as particular about them cobwebs as Sir Richard was.'

'That is true; cobwebs and spiders, that was Sir Richard's hobby, and it is the captain's too. He is never happier than when he is in that study with his spiders.'

'Ah! it is a queer world,' said Mrs. Martin, 'and some of the queerest things in it are spiders.'

So they are. 


\title{
APPENDIX.
}

\section{$\longrightarrow$ \\ TABLE OF BRITISH SPIDERS.}

\section{Tribe I. OCTONOCULINA. Eight-eyed Spiders.}

\author{
FAMILY I. MYGALID正.
}

Atypus Sulzeri. Eggs enclosed in white cocoon, placed in subterranean cell. Eight eyes, four large, four small. Glossy; cephalothorax very large, reddish brown. Only British species of Trapdoor Spider.

\section{FAMILY II. LYCOSID丑. Wolf Spiders.}

Genus I. Lycosa. Eggs yellow or white, enclosed in cocoon, white or pale brown, and carried by the mother. All have eight eyes, four large and four small.

Lycosa agretica. Dark brown, hairy.

- oampestris. Shield reddish brown, legs hairy.

andrenivora. Brown, shield hairy.

rapax. Brown, hairy.

herbigrada. Light brown, darker pattern on body.

allodroma. Cephalo-thorax large, abdomen hairy.

picta. Hairy, cream spots.

saccata. Brown; legs hairy.

lugubris. Like saccata, with pale band.

obscura. Dark brown, with faint spots.

exigua. Dark brown, hairy.

fluviatilis. Dark grey, yellowish, striped and spotted.

--- cambrica. Hairy; shield large and dark.

latitans. Dark brown; found in damp places.

piratica. Yellowish brown; found in marshy places in June. piscatoria. Shield glossy, hairy, brownish.

Genus II. Dolomedes. Cocoon carried under breastplate; cocoon brown. Eight eyes. Found in woods; aquatic in habits.

Dolomedes mirabilis. Abdomen long and tapering; colour varies.

ornatus. Yellowish; abdomen egg-shaped.

fimbriatus. Large, hairy, dark brown, yellow stripes.

Genus III. Hecaërge. Cocoon flat, white, attached to stones. Active.

Hecaërge spinimana. Pale brown, hairy; abdomen egg-shaped. 
Genus IV. Sphasus. Eight eyes, two large, six small. Cocoon white and long. Leaps on prey.

Sphasus lineatus. Brown, legs pale, breast-plate heart-shaped.

\section{FAMILY III. SALTICID正. Leapers.}

Genus I. Eresus. Eight eyes, four close together in front.

Eresus cinnabarinus. Shield black, two red spots, abdomen red, spotted black. Very rare.

Genus II. Salticus. Eyes in three rows.

Salticus scenicus. One or two white cocoons, hidden in walls. Black, white zebra marks. Common.

— sparsus. Dark brownish black, white marks.

_ coronatus. Abdomen egg-shaped. Male and female vary much.

- xanthogramma. Medium size, yellowish. Rare.

- frontalis. Eggs in oval cell. Brown, fine black spots on abdomen.

obscurus. Very broad, dark brown."

distinctus. White cocoon, hidden in crevices. Brown, breastplate oval.

- floricola. Legs thick and hairy. White markings.

- gracilis. Cephalo-thorax raised in middle, abdomen egg-shaped.

— cupreus. Eggs in sac or cell placed in nest of white silk. Colour and marks vary.

- notatus. Brownish black, white hairs. Legs thick.

- promptus. Yellowish, hairy.

_ reticulatus. Small, light brown. Legs pale and hairy. Found in woods.

-_ Jenynsii. Hairy, marked with faint lines.

-_- Blackwallii. Abdomen long, tapering, oval.

- tardigradus. Cocoon white and flat. Hairy, dark brown, grey band on abdomen.

- formicarius. Cocoon small and nearly round. Abdomen eggshaped, pointed at both ends. Resembles an ant.

\section{FAMILY IV. THOMISID正.}

Genus I. Thomisus. Eight eyes, nearly same size.

Thomisus brevipes. Yellow patch on shield; covered with short hairs. Legs short.

_ cristatus. One white long cocoon. Brown, covered with short black hairs. Very common.

audax. Brown, yellowish white marks and patterns. Legs hairy. mottled, dark. Not common.

sabulosus. Pale with dark mottled bands and zigzag marks. Legs hairy, pale with dark marks.

atomarius. Shield yellow; abdomen reddish brown. Legs yellow and dark marks. 
Thomisus formosus. Breast-plate heart-shaped ; abdomen egg-shaped, red. Legs greenish in female, red in male.

floricoleus. Sexes differ in colour and marks. Four front legs very long.

luctuosus. Cocoon flat, white, found in June. Shield brown, dark lines, abdomen pale, dark marks. Found in woods and pastures.

bifasciatus. White, flat cocoon, found on under-side of leaf. Reddish brown, pale lines.

Cambridgii. Abdomen reddish brown, rather hairy shield, brown, white marks. Legs hairy.

pallidus. Pale yellow both above and below. Legs pale and hairy.

versutus. Shield pale; abdomen greyish yellow, marked with brown. Legs hairy.

tristis. Sides black, shield red-brown, abdomen dark. Female undescribed.

incertus. White, flat cocoon. Abdomen flat, overhanging, slightly hairy.

claveatus. Shield and abdomen pale, with dark streaks and marks.

cinereus. Shield mottled, zigzag bands on abdomen. Legs pale brown and hairy.

citreus. Female yellow, male striped green and black. Found in flowers.

abbreviatus. Abdomen large, broad, hairy; spider yellow. Sometimes whitish or pale pink.

Genus II. Philodromus. Eyes in two crescent rows; males usually smaller than females.

Philodromus dispar. Sexes differ. Abdomen hairy. Legs long, spinous.

pallidus. Cocoon white, grey, shield brown marks. Legs long.

elegans. Pale brown, darker marks. Legs pale and spinous.

cæspiticolis. Two flat white cocoons in nest. Pale brown, darker marks, abdomen hairy. Found on furze and heath.

Clarkii. Reddish brown, darker specks. Eyes on whitish spots.

variatus. White, flat cocoon, found in June. Pale specks, dark brown mixed. End eyes largest.

mistus. Same as above. Shield hairy, pale brown.

aureolus. Shield mottled, abdomen brown.

oblongus. Yellowish white, brown markings.

Genus III. Sparassus. Four eyes of equal size; two larger, two smaller; eight in all. Abdomen long, egg-shaped; breast-plate heart-shaped.

Sparassus smaragdulus. Cocoon large, round, green. Female and young male green, adult green with red and yellow marks. Very active. 


\section{FAMILY V. DRASSID丑.}

Genus I. Drassus. Eyes in two rows; abdomen long oval, breast-plate oval or heart-shaped, legs strong.

Drassus ater. Cocoon placed in cell. Black. Nocturnal.

-_ lucifugus. Two cocoons, flat and white, found in June. Abdomen black, shield and breast-plate brown and hairy. Rare.

___ pusillus. Slender, black, legs ruddy and yellow. Eyes nearly straight.

-- pumilus. Black or dark brown except legs. Less than one-sixth of an inch.

- clavator. Shield pale brown, black abdomen with red hairs and three small whitish spots. Female not described.

sericeus. Shield and breast-plate brown, abdomen greenish-brown. Found in old houses.

-_ sylvestris. Cocoon white, flat, hidden in a cell underground. Shield and breast-plate reddish brown, abdomen dull green. Female found with cocoon often.

cupreus. Cocoon like sylvestris. 'Pale reddish-brown and very hairy. Legs hairy.

lapidicolens. Cocoon like sylvestris. Shield red-brown, abdomen brownish grey with darker streak. Mother conceals herself with cocoon.

ferrugineus. Abdomen cream-coloured; shield red-brown, both long and oval.

micans. Shield red-brown, white hairs, abdomen deep black, rather hairy. Spider glossy.

nitens. Small white cocoon, with tube in which mother lives. Beautifully marked and coloured. Runs on ground in spring and summer.

propinquus. Dark brown; two yellow spots and lines. Legs long and thin.

Genus II. Clubiona. Legs strong. Spinnerets welldefined. Eyes in two transverse rows.

Clubiona holosericea. Cocoon placed in tube or cell. Shield pale olive-green, abdomen covered with grey hairs. Eyes nearly straight rows.

amarantha. Cocoon placed in tube or cell. Shield yellow brown, abdomen hairy and red-brown. Legs pale and hairy. epimelas. Cocoon white, found in stone walls. Brown; black marks, pale hairs. Found under dead leaves.

formosa. Shield pale brown, abdomen red-brown with white lines and streaks. Very rare.

corticalis. Cocoon found in silken cell. Dark brown, paler lines, hairy. Cell fastened to leaf.

brevipes. Dark brown, legs pale yellow. Can leap.

comta. Cocoon found in silken cell. Brown, pale patches and spots. Rare. 
Clubiona pallens. Covered with short hairs; yellow-brown.

- accentuata. Cocoon open at both ends. Brown, two $\Lambda$-like marks. Rapidly moves; found in woods.

— domestica. Brown; sides mottled paler. Eyes on black spots. nutrix. Yellow; brown stripe and pale spots. Very rare.

erratica. Cocoon very loose, white, in nest. Shield red-brown, abdomen olive-green. Nest guarded by furze.

\section{Genus III. Argyroneta.}

Argyroneta aquatica. Forty to a hundred yellow eggs enclosed in cocoon. Abdomen olive, very hairy, breast-plate brown. Lives mostly under water.

\section{FAMILY VI. CINIFLONID丑.}

Genus I. Ciniflo. Eyes in two rows, varying in size. Eight spinnerets.

Ciniflo atrox. Cocoon hidden in silken cell. Shield dark and glossy; abdomen hairy and brown, with yellow lines and black spots and streaks. Very poisonous bite.

similis. Very like atrox, but larger.

ferox. Abdomen brown, speckled white, white spots and lines. Affects dark places.

mordax. Reddish brown, greenish browll.

humilis. Brown; abdomen round, egg-shaped.

Genus II. Ergatis. Eyes in two rows, breast-plate heartshaped. Abdomen oval.

Ergatis benigna. Two or three cocoons placed in a snare. Shield dark brown, abdomen nearly white. Very bold.

pallens. Yellow and hairy with dark spots.

latens. Like benigna, but cocoons greenish. Abdomen grey and black, shield darik brown. Habit like benigna.

Genus III. Veleda. One pair of spinnerets united. Eyes in two crescents.

Veleda lineata. Shield brown, then paler stripes; abdomen yellow with three brown stripes. Covered with white hairs.

\section{Family VII. AGELENID无. Foragers.}

Genus I. Agelena. Spinnerets form a cluster. Eyes in two rows. Breast-plate heart-shaped. Abdomen egg-shaped. Legs rather long.

Agelena labyrinthica. Shield red brown, edges dark; abdomen brown and yellow, with oblique marks. Web large, strong and beautiful. 
Agelena prompta. Brown, hairy, pale underneath, small. Found under stones.

— elegans. Cocoon with five or six eggs. Shield yellow-red; abdomen dark brown, pale lines; spinnerets in a row. Web spread over holes in the earth.

- montana. Shield brown, glossy, indented; abdomen very hairy, black, pale spots. Under stones and in moss.

— nava. Shield dark brown, abdomen nearly black. Found on the ground.

— brunnea. Cocoon suspended from twigs. Green; eyes on black spots. Spinnerets short.

- celans. Dark brown, pale marks, legs hairy. Rare.

gracilipes. Brown above, yellowish below.

Genus II. Tegenaria. Legs thin and very long. Eyes nearly equal, in two rows.

Tegenaria domestica. Several flat cocoons. Eyes form a square, end eyes on tubercles. Brown, with black and yellow marks. Large, legs very long.

- atrica. Hairy, pale brown, black spots and blotches with pale pattern. Found in greenhouses, etc.

civilis. Like domestica, but smaller cocoons. Shield red-brown, dark marks; abdomen pale olive-green, triangular spots down middle. Legs long, thin, hairy.

silvicola. Shield pale brown; abdomen yellow and brown.

Genus III. Cæælotes. Breast-plate heart-shaped. Abdomen oval. Legs thick.

Cælotes saxatilis. Shield red-brown; abdomen black stripe down centre, sides yellow-brown.

Genus IV. Textrix. Eyes in two curved rows. Abdomen egg-shaped. Breast-plate heart-shaped.

Textrix lycosina. Cocoon attached to a stone. Shield black; abdomen black with pale spot. Web, horizontal sheet.

\section{FAMILY VIII. THERIDIID Æ.}

Genus I. Theridion. Eyes in two curved rows, end eyes on tubercles. Abdomen overhanging cephalo-thorax. Webs spun on bushes.

Theridion lineatum. Cocoon blue green covered with silk. Pale green or yellow, sometimes marked with crimson. Common.

Carolinum. Cocoon carried by mother; round, white. Sexes vary in colour. Legs long and thin. Very rare.

versutum. Shield brown, glossy; abdomen black with white marks. Legs pale, long, thin and hairy.

quadripunctatum. Cocoon round, pale yellow. Dark glossy brown, with two curved lines of white spots on abdomen. Common. 
Theridion sisyphum. Cocoon red brown, flat, in a silken tent. Sexes vary in colour and markings. Found in large trees.

nervosum. Cocoon green, silken, round, in beautitul tent. Shield yellow and brown; abdomen glossy, beautifully marked in black, white and red. Small, beautiful.

pictum. Shield pale brown; abdomen speckled brown, red band down middle. Legs very long.

denticulatum. Cocoon round, olive green. Dark brown, pale spots. Legs pale and hairy.

simile. Shield dark brown; abdomen large, nearly round, brown and yellow speckled. Legs long, thin.

varians. Cocoons several, round, white. Shield pale yellow, black edges and black spot.

tinctum. Pale yellow with black spots. Legs long, thin and spinous.

pulchellum. Cocoon found in June; white. Shield olive-brown with broad black stripe; abdomen pale yellow bands and reddish stripe.

stictum. Glossy; shield very dark, abdomen brown. Legs short, thin.

-_ inornatum. Shield yellow-red, abdomen black. Legs hairy, red.
-_ - riparium. Cocoons several in a cell. Shield glossy; abdomen brown mottled, black and white.

- pallens. Cocoon pear-shaped, white, fine texture. Female nearly white, marks vary.

haematostigma. Brown and grey with pale and dark lines and red spots. Legs long, hairy, pale.

- albens. Nearly white, with fine black rings.

variegatum. Pear-shaped cocoon, suspended by stalk. Shield pale black spots, abdomen black and red with black lines and white spots. Cocoon contains six eggs.

signatum. Shield rough, dark brown; abdomen dark, yellow crescent and three yellow spots. Rare. Legs thick.

angulatum. Abdomen notched in front, with angular projections, pale brown, white marks. Legs pale in rings.

fuscum. Glossy, dark, brownish red. Legs strong, hairy.

filipes. Glossy, brown; abdomen egg-shaped. Legs long, thin, hairy.

guttatum. Glossy, very dark brown, covered with tiny marks.

flavo-maculatum. Glossy, red brown, black streaks.

auratum. Shield glossy; abdomen yellow, coarse dark hairs. Legs thin, dark.

\section{Genus II. Pholcus.}

Pholcus phalangioides. Eyes on prominent black spots. Legs very long and thin. Cephalo-thorax round, abdomen long and cylindrical. 


\section{FAMILY IX. LINYPHID无.}

Genus I. Linyphia. Eyes in two rows. Legs long and thin. Threc claws to fect. Abdomen egg-shaped; cephalothorax oval and glossy; breast-plate heart-shaped.

Linyphir montana. Cocoon white, hidden under a stone. Glossy; shield pale brown; abdomen differs in male and female. Very common.

triangularis. Shield brown; abdomen yellow and black, hairy.

Legs hairy.
cauta. Glossy, pale brown with darker and white spots. Nocturnal habits.

vivax. Abdomen yellow brown, white specks ; breast-plate dark brown. Hairy legs.

- crypticolens. Cocoon fastened to spinnerets. Pale yellowish brown. Found in cellars.

anticeps. Glossy, yellow with darker marks.

- tenuis. Glossy; abdomen yellow, dark marks. Common.

- terricola. Brown, black and white marks, male paler than female. Found in woods.

insignis. Glossy, yellowish, various markings. Legs hairy.

pulchella. Abdomen pale, darker marks. Legs hairy, pale brown.

circumspecta. Very small, one-fourteenth of an inch, pale brown, glossy.

rubea. Brown, white and yellow marks. Found in woods.

alacris. Pale brown, white mottlings, black stripes. Legs pale and hairy.

- ericea. Brownish, glossy; male much the smaller.

- pernix. Yellowish brown, black markings. Legs red.

-- albula. Pale yellow, brown stripes. Legs pale.

- tenella. Greenish brown, glossy. Legs hairy.

- socialis. Markings various. Legs pale, dark rings.

- Meadii. Greenish brown, pale streaks. Legs hairy.

- marginata. Broad brown border, spotted white.

- fuliginea. Very dark, underneath nearly black.

minuta. Dark brown, underneath nearly black, glossy.

- pulla. Glossy, dark. Legs pale and hairy.

nigella. Very dark brown. Legs pale, hairy, thorny.

furva. Glossy, dark brown. Legs paler, hairy.

- obscura. Nearly black, pale marks. Legs reddish.

gracilis. Dark and glossy.

- pratensis. Dark brown, glossy, white marks. Common.

- flavipes. Nearly black, glossy. Legs very long and yellow.

- Claytoniæ. Very dark and glossy. Legs bright yellow.

longidens. Reddish brown, glossy ; eyes on black spots.

frenata. Pale brown, black and white marks. Rare, very long legs.

nasata. Pale brown, darker marks. 


\section{Genus II. Neriëne.}

Neriëne bicolor. Glossy. Legs thorny. Common, found under stones.

- rufipes. Glossy, brown, rather hairy. Legs paler.

sylvatica. Glossy, brown.

rubripes. Glossy, brown; abdomen black.

livida. Cocoons round and white. Very dark. Legs strong and hairy.

Huthwaitii. Dark brown and hairy. Legs thin and hairy.

cornigera. Glossy, yellowish brown; palpi have horn-like appendage. Legs thin and hairy.

agrestis. Dark brown. Legs hairy.

longipalpis. Black and glossy. Can live under water.

rubens. Glossy and yellowish. Found on heath and grass.

- pilosa. Pale yellow brown. Legs hairy.

trilineata. Abdomen whitish with thin dark lines. Legs pale, dark rings.

- marginata. Blackish with pale lines. Web made on grass.

affinis. Dark brown, paler marks.

- munda. Sexes vary. Legs pale red.

- carinata. Hairy, dark grey, pale lines. Brown legs.

GENUS III. Walckenaëra. All dark, without pattern on abdomen.

Walokenaëra acuminatha. Legs bright red.

obtusa. Legs red.

pratensis. Yellowish red legs.

Hardii. Light brown legs.

Genus IV. Pachygnatha. Legs long and thin.

Pachygnatha Clerckii. Olive-brown, yellow stripes. Legs pale brown. _ Listeri. Yellow stripes, white angles on brown ground.

Degeerii. Olive-brown, black and white markings. Yellow legs.

\section{FAMILY X. EPËIRID无.}

Genus I. Epëira. Long legs; abdomen overhanging.

Epëira quadrata. Cell dome-shaped. Abdomen greèn, amber and brown, with four large oval marks. Very beautiful.

adianta. Rich brown, cream-coloured marks. Very beautiful.

apoclisa. Cell like quadrata. Black; yellow mottlings. Legs strong and hairy.

sericata. Brown, paler marks. Legs long, strong and hairy.

scalaris. Abdomen yellow with triangular brown patch. Handsome.

umbratica. Greyish black. Dingy, flat, hideous.

diadema. Yellowish red with a cross of white spots. Garden spider. 
Epëira angulata. Abdomen triangular, with two large tubercles, cream-coloured and brown.

— callophylla. Abdomen silver-grey, with fine black marks. Legs with black rings.

- acalypha. Abdomen yellowish, with black spots and dashes.

- bella. Yellowish brown, darker markings. Legs short and hairy.

- inclinata. Pretty, pale greenish grey with darker markings.

- conica. Hump on abdomen, which is pale; shield dark. Looks crushed.

Genus II. Tetragnatha.

Tetragnatha extensa.

\section{Tribe II. SRNOCULINA. Six-eyed Spiders:}

\section{FAMILY I. DYSDERID正.}

\section{Genus I. Dysdera.}

Dysdera erythrina. Abdomen cream-coloured; cephalo-thorax dark red. Nocturnal.

rubicunda. Abdomen cream-coloured; cephalo-thorax dark red; falces long. Smaller than above.

Hombergii. Shield black, body long, abdomen yellow-brown.

Genus II. Segestria. Legs long and strong.

Segestria perfida. Grey; shield brown. Rare.

- senoculata. Glossy, brown.

Genus III. Schœnobates.

Schœnobates Walkeri. Brown, several shades.

Genus IV. Oonops. Long legs.

Oonops pulcher. Abdomen red, shield yellow. Not rare.

FAMILY II. SCYTOTID丑.

Genus I. Scytodes. Legs thin and very long.

Scytodes thoracica. Abdomen pale yellow. Front legs longest. 


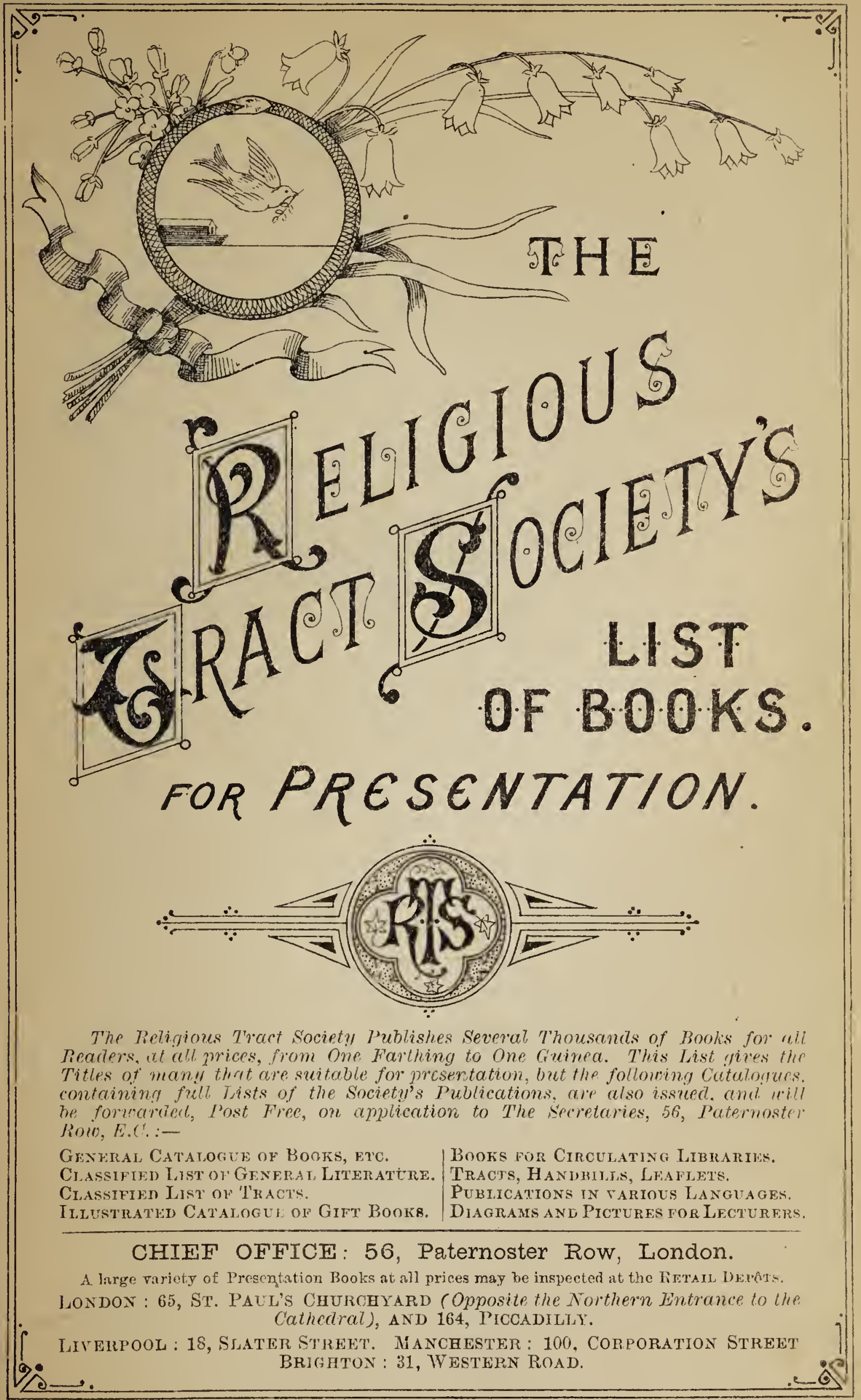

The Reliarous Traot Soctety, Londor. 


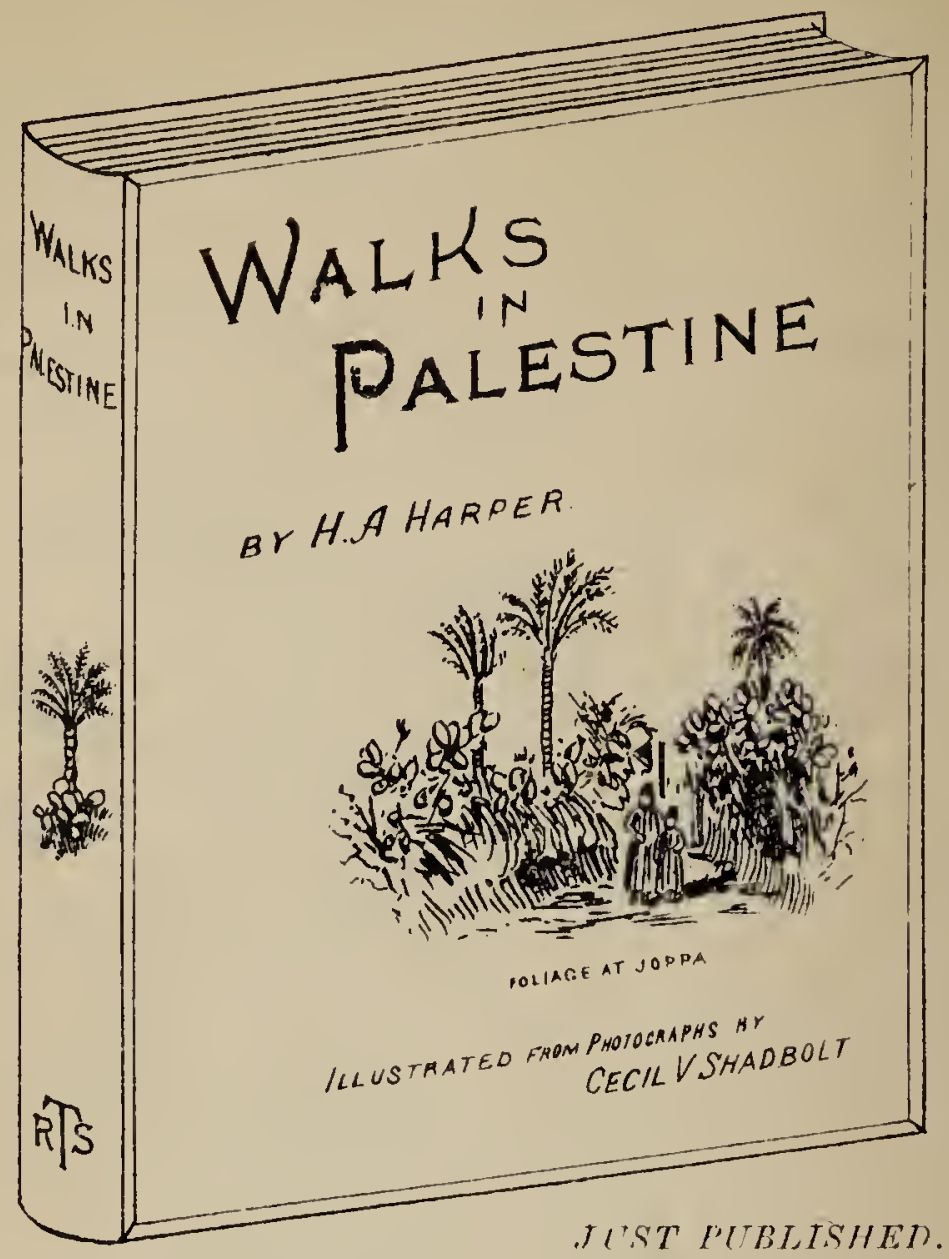

\section{WALKS IN PALESTINE.}

The letterpress by HENRY A. HARPFR, author of "lllustrated Letters to my Children from the Holy Land," etc. Illustrated by twentyfour photogravures from photographs taken iy C. V. Sнanвor., lisq. Royal Quarto. 25s, bevelled boards, gilt edges.

N.B.-Of this book there is also an edition rle luxe, limitel to 100 copies. The plates are on India paper, the lesterpress on hand-made paper, and the volume is handsomely bound in classic vellum, with gilt top and uncut edges. Irice 45̃s.

This rolume forms a superb gift-book and souvenir of the Holy Land. Mr Sharlbolt's photographs are of the highest merit, and they have been most beautifully reprodueed by Messrs. Annan and Sw:m. The letterpress is from the pen of Mr. IIarper, who has lived in Palestine, and is familiar with every spot shown in the iliustrations.

\section{THE LANDS OF SCRIPTURE}

Illustrated by Pen and Pencil. Containing "Those Holy Field;" and "The Land of the Pharaols." by SAMUel Marvisg, LL.D.: and "Pietures from Bible Lands," by S. G. Cirwer, D.D. Imperial 8vo. 2lk. handsomely bound in eloth gilt.

This elegantiy botund and profusely illustrated rolume forms a very suitable Presentation Fook to a Minister, smiday-sehool Superintendent, or Teacher. It gives, in a concise and interesting form, a large amount of information about the plaees mentioned in Seripture, such as would prove of great service to everr Bibl. student 


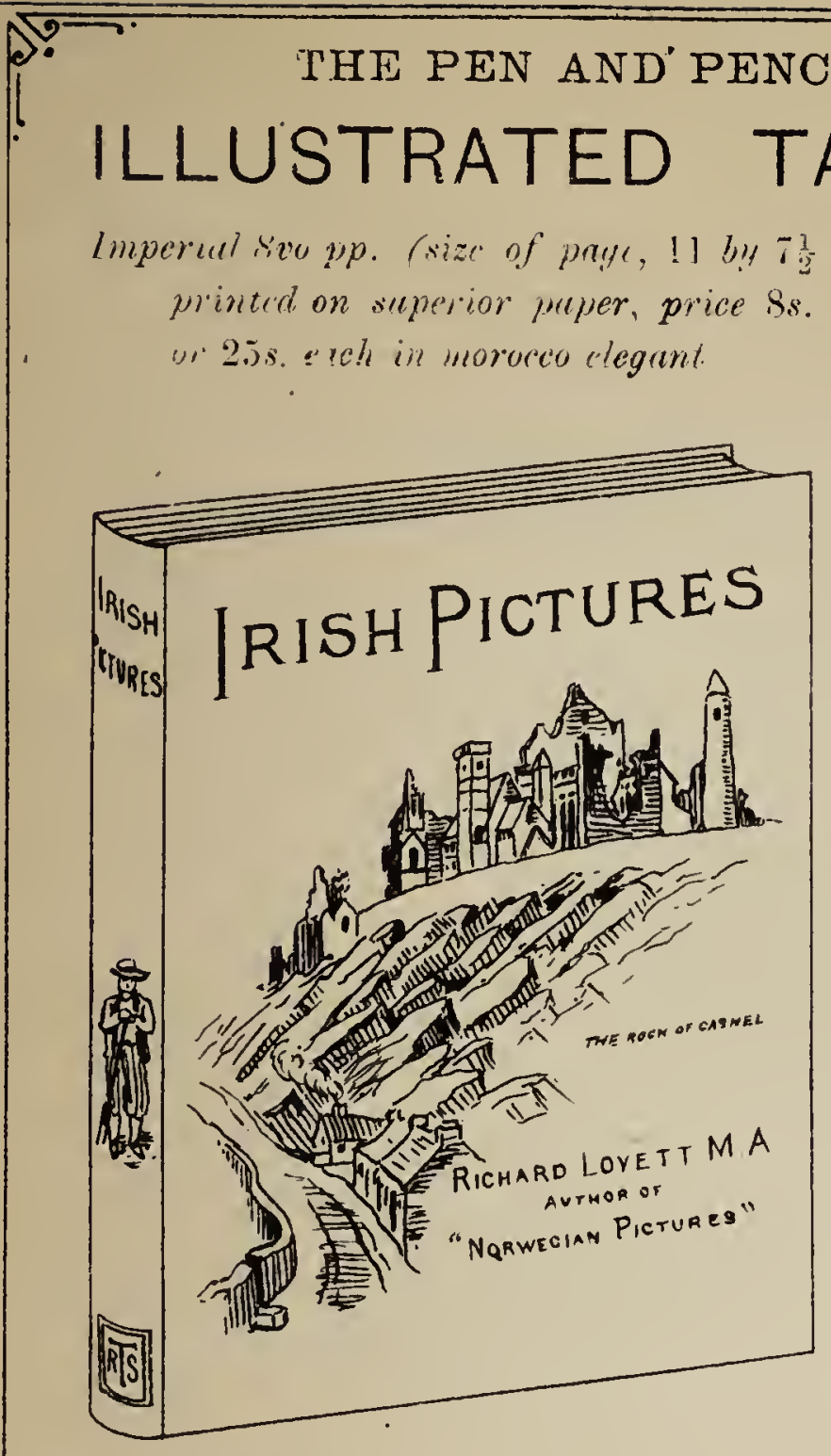

printed on superior puper, price $8 s$. in handsome cloth, gult edges. "2.5s. sech in mororco elegant.

Jist Published.

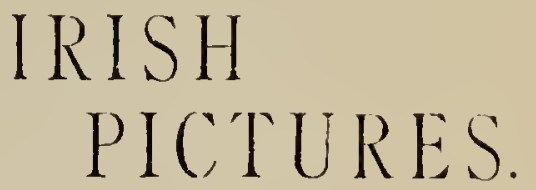

Drawn with l'en and Penchl.

BI RICHARD I,OVE'I'T, M.A.

Author of "Norwegian Pictures," "lictures from IIolland," ctc. With a map) and over one hundred Illustration: from sketches and Photographs. Inmperial 8vo. 8s. handsome cloth boards, gilt edges, or 25s. bound in morocco, gilt edges.

"Contains some pleasant writing on the natural beauties and -antiquities of Ireland." Daily Telegraph.

"The descriptions can be commended for their truth and fulness."-1lunchester Guamliun.

"A really splendid volume." - Cork Herald.

"T'be illustrations are excellent." - Irish Ecclesiastionl (inzette.

American Pictures. Drawn with Pen and Pencil. Bv Samuel Maxing, Lt.1. New Edition. Profuscly Illustrated. 8s. in handsome cloth gilt; or $25 \mathrm{~s}$. in morocco elegant.

"The text is clear and vigorous, and the numerous illustrations which heal" it compans are a striking complement to its descriptions."-Guardian.

Italian Pictures. Drawn with Pen and Pencil. By SAMles. MAnning, r...D. New Edition. Revised. withadditions by Jr. S. G, Gums. l'rofusely Illustrated. New Fdition. 8s. handsome cloth gilt; or 25s. in moroceo elegant.

French Pictures. Drawn with Pen and Pencil. By Dr. Saxier G. Greas. With tine Engravings. 8s. in loandsome cloth gilt: or 25 s. in moloceo elegant.

"Gires a graphic notion of the general aspect of France and its inhabitant-." Standard.

Pictures from the German Fatherland. Drawn with Pen and Pencil. By Dr. SAMUEL (i. GreEN. With fine Engravings. 8s. handsome eloth. or 25s. in moroceo, elegant.

"Wc can reconmend the work as a capital and cheap present." - A rt .Ioumnal

Pictures from Holland. Drawn with Pen and Pencil. Ry Richaru LovetT, м.A., Anthor of "Norwegian Pictures," ete. With one hundred and thirty-two illustrations. Imperial 8ro. 8s. handsome cloth. gilt edges: or $25 \mathrm{~s}$. bound in morocco clegant.

"A cliarming book, prettily illustrated, and prettily written."-Saturday lievieue.

"The artist has succeedcd in pourtraring all the morc intcresting phrses o" Dutch life and scenery with ficlelity and spirit."-Morning Post. 


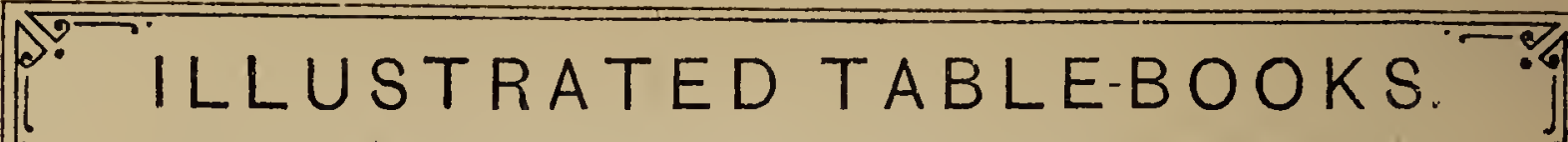

The "PEN AND PENCIL SERIES."- comtinupd

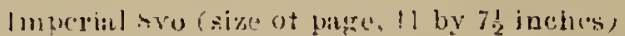

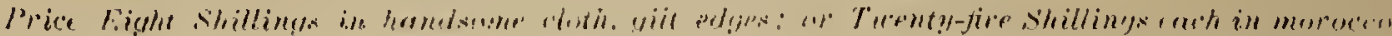

English Pictures. Mrawn with Pen and Pencil. By Samete.

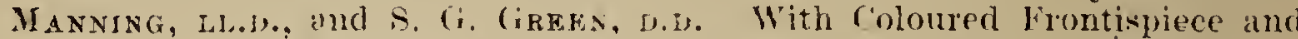

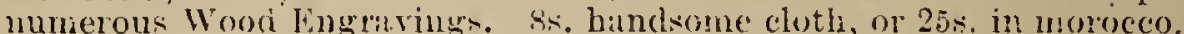

Nest to seeing the veatiful places of the parth comes the deliglit of reiding of then ; and

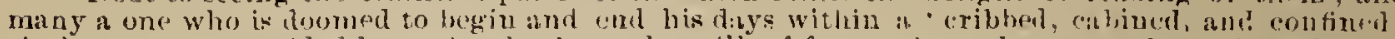
circle, can roam, guderi by such it bowk, at the will of fancy, though sumny ghales, by talobling strenus, or over the breesy moorlimis." - lime.
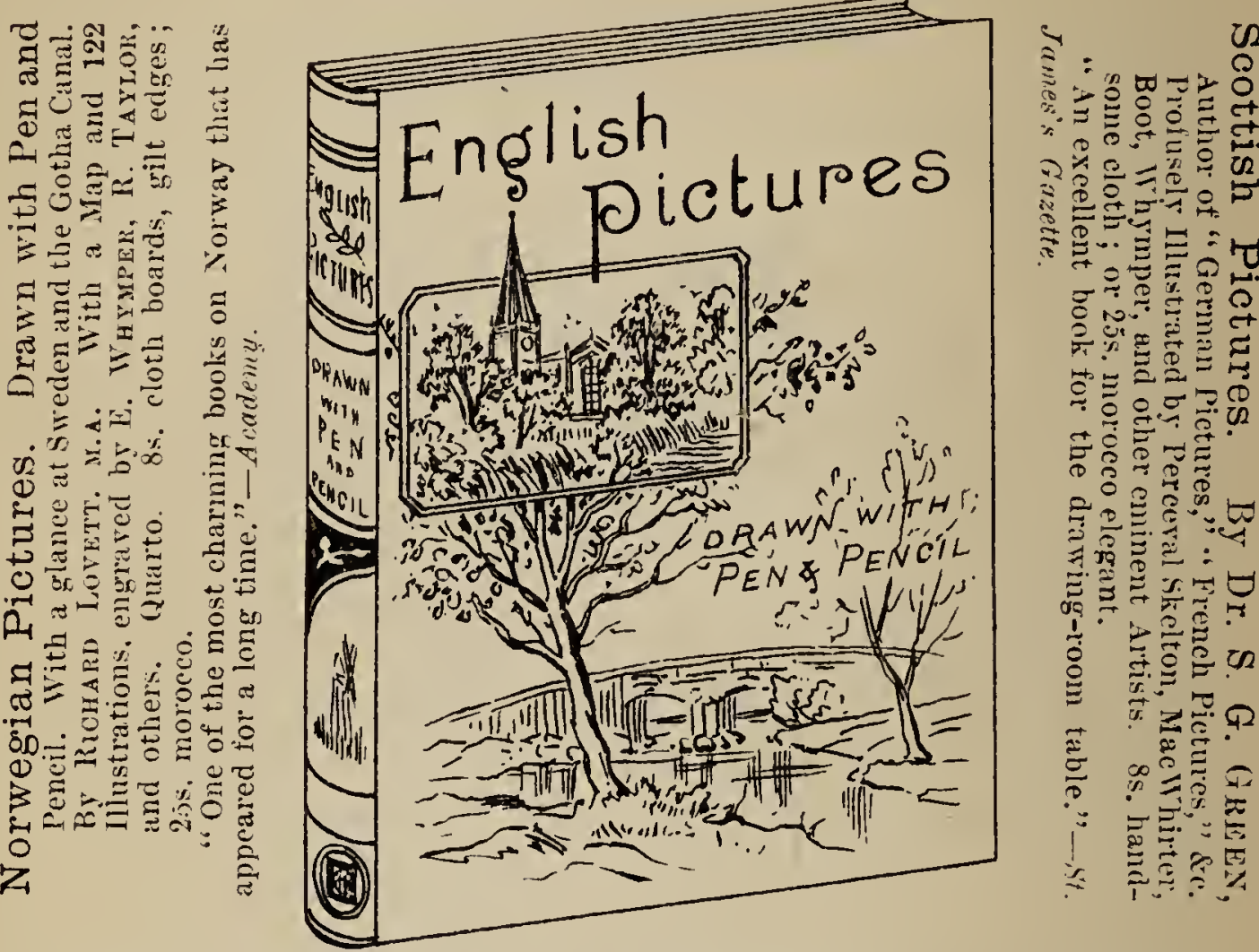

Canadian Pictures. Irawn with

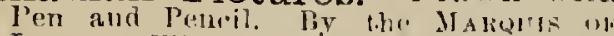

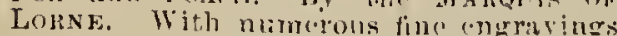
hy k. Whymper. frons sketclen las the

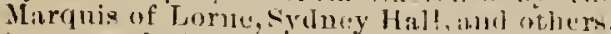
Ss. estra cloth hoardis silt; or zis. bound in inorocen eleviout.

Most interestimg-an extreme:ly jlensint book."-sulurdery lieve ifue.

Australian Pictures. Drawn with

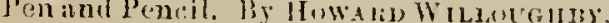

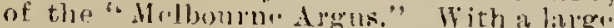
Map and Illustritions from Phowiogratuh and sketwhes, engrated by whymper anth others. Imperial syo. Bs.. landsume eloth, gill edgre: 2 is moroc(o) elegant.

"Therse pietures ate real, virid, and !ife-like. Ther ate writiten by a math who belonge to the

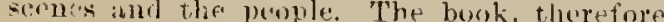
will he is fitting memerial to tourists of whe

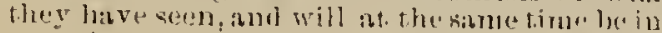

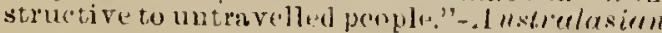

\section{Indian Pictures. Drawn with Pon}

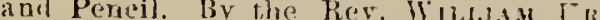

Wick, M.A. Profuse]y [llinstrated, ss, in

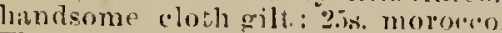

The soniety, in all their excellens series of

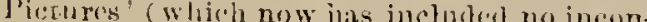

siderable part of the worlia). lans nut, given to the jublic : botedexeruted or mure interestins volume than this."-sinetertor.
Sea Pictures. By Ir. MAchlar, Fiditor of the Lrisure Hour de. Contain-

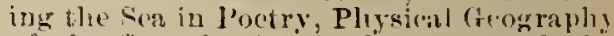
of the Sist the seit in History, and the Harvest of the seat. Ss. in liandsume cloth ur 2.5s in morocen we trant.

Mr. Rnskin salys:- "Tlis beantiful bonk is by far the best I have evere secto on the mhiject. and will be a nant precions erift-book for ne."

"Those Holy Fields." l'alestine illustrated by Pt:n iznd Pencil. IBv t.lu"

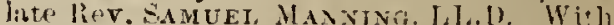
numerons Engrarings. bs., hitudiome elotl. gilt: : 2is. nowror"

Pictures from Bible Lands Driawn witli Pen and P'encil Estited by the ler, s. (i. Grew. D. I), The Engriring's hy Elward Whymper ant orhers.

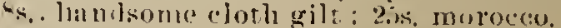

\section{New Ellition. Just l'ublishy.r.}

The Land of the Pharaohs. Egypt and sinat. Illustruted by l'en atur

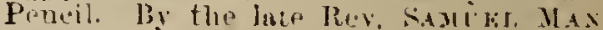
xist: L.I.I). With numerons tine En-

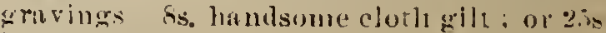
in nusuero.

Swiss Pictures. Drawn with lea

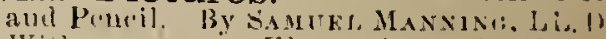
With numerous [lfustrations. Sx. lianul some cloth gilt : 2.5s, morocco. 


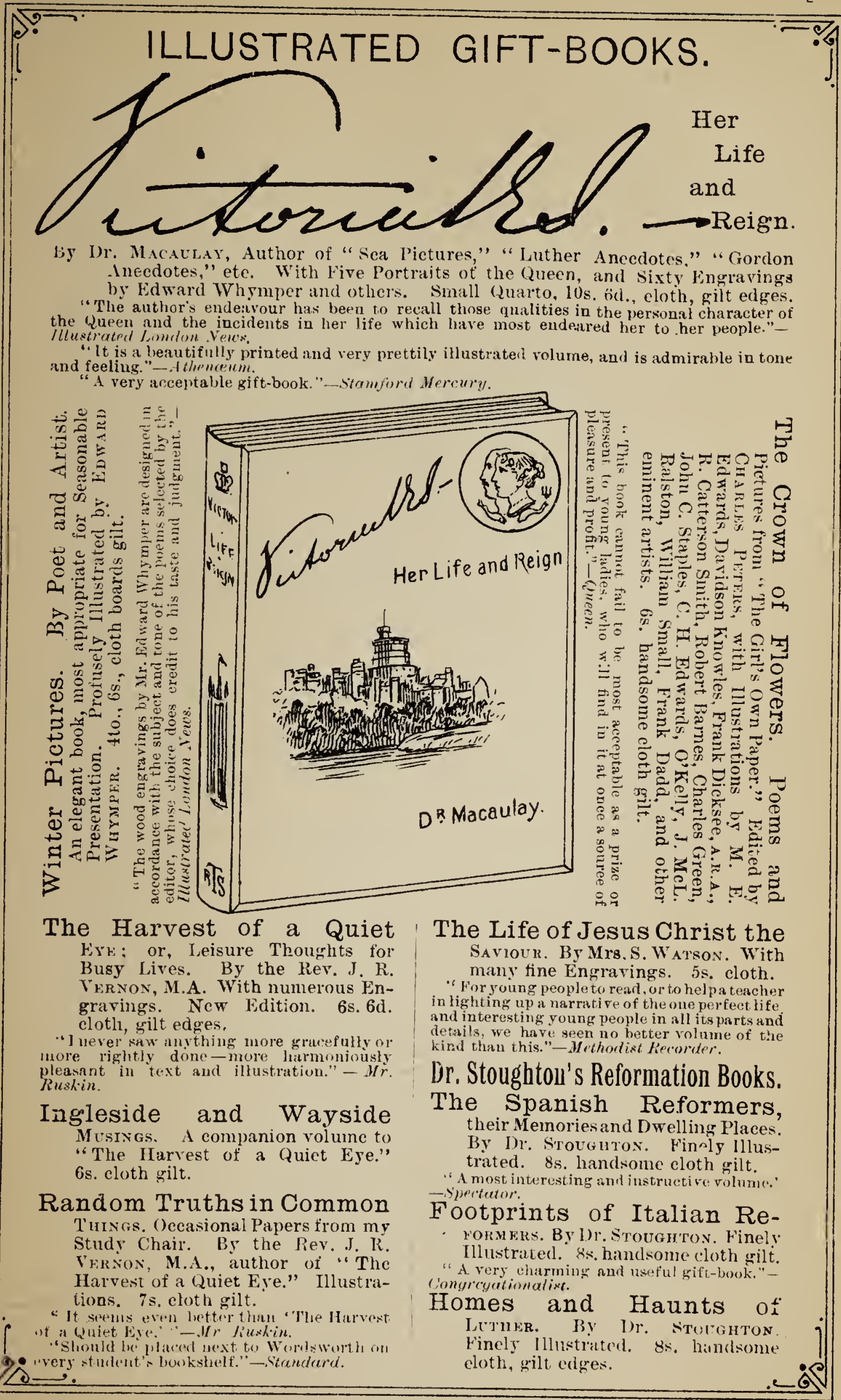


To a Minister or Sunday School Teacher.

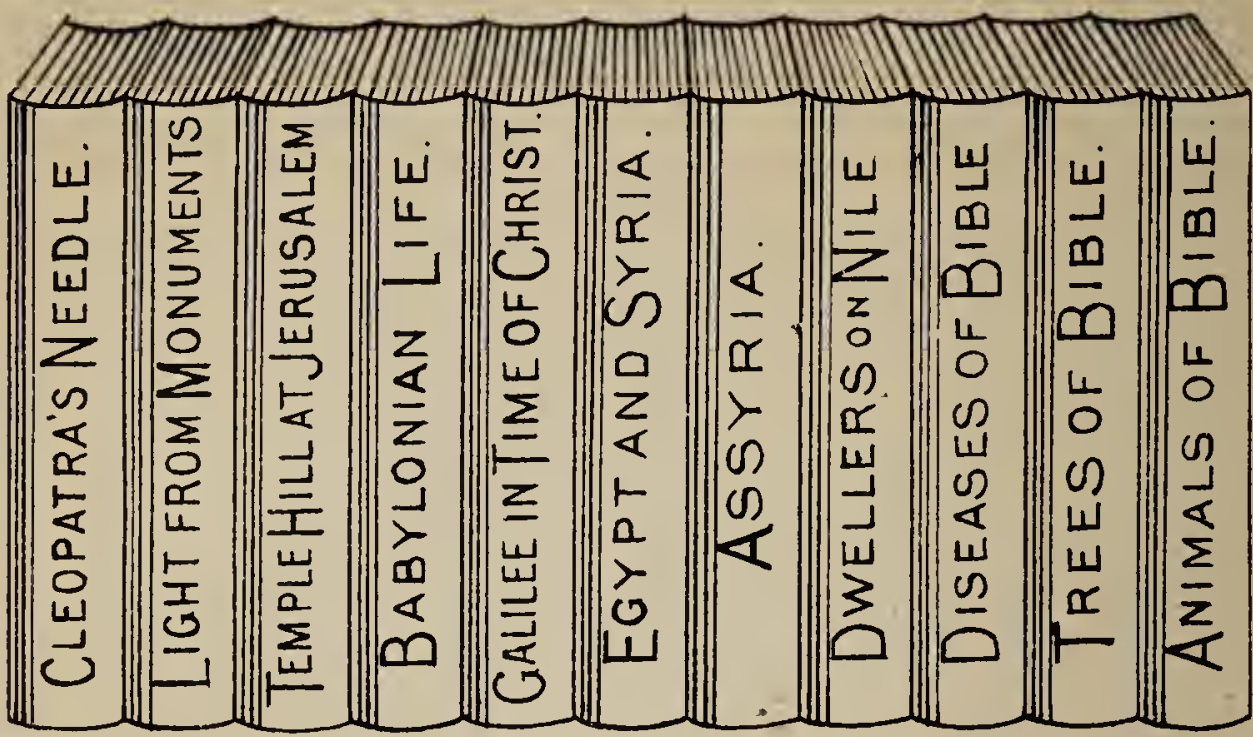

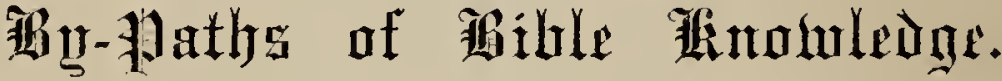

-The rolumes which the Tract Society is issuing under the above title fully deserve success. They have been entrusted to scholars who have a special acquaintance with the subjects about which the severally treat."-The Athenceum.

1. Cleopatra's Needle. By the Rev. J. KINr, Tecturer for the Palestine Exploration Fund. With Illustrations. 2s. 6d.

2. Fresh Light from the Ancient Monuments. By A. H. SAYce, L..1., Deputy Professor of Comparative Philology. Oxford, ete With Facsimiles from Photographs. 3s.

3. Recent Discoveries on the Temple Hill at Jerusalem. By the Rev. J. Krvg, M.A., Lecturer for the Palestine Exploration Fund. With Maps, Plans, and Illustrations. 2s. $6 \mathrm{~d}$.

4. Babylonian Life and History. By E. A. WAllis BungE, M.A., Cambridge, Assistant in the Department of Oriental Antiquities, British Museum. 3s.

5. Galilee in the Time of Christ. By Selah Merrill, D.D., Author" of " Kast of the Jordan." With a Map. 2s.6d.

6. Egypt and Syria. Their Physical Features in Relation to Biblc History. By Sir J. W. DAwson, F.G.S., F.R.s. With many Illustrations. $3 \mathrm{~s}$.

7. Assyria: Its Princes, Priests, and People. By A. H. SAYCE, M.A., LL.D. Illustrated. 3s.

8. The Dwellers on the Nile. Chapters on the Life, Literature, History, and Customs of Ancient Egypt. By E. A. WALLIS BUdGK, M.A., of the British Museum. Illustrated. 3s.

9. The Diseases of the Bible. By Sir J. Risdor BennetT, M.D., F.R.s., kx-President of the Koyal College of Physicians. 2s.6d.

10. Trees and Plants of the Bible. By W. H. Groser, B.Sc. Illustrated. Crown 8ro. 3s. cloth.

11. Animals of the Bible. By H. Chichester Hart, B.A., Naturalist to Sir G. Nares' Aretic Expedition and Professor II ull's l'alestine Expedition. Illustrated. Crown 8vo. 3s. 


\section{HANDSOME GIFT-BOOKS \\ FOR}

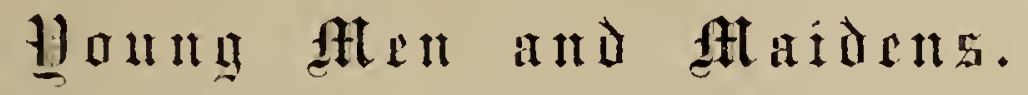

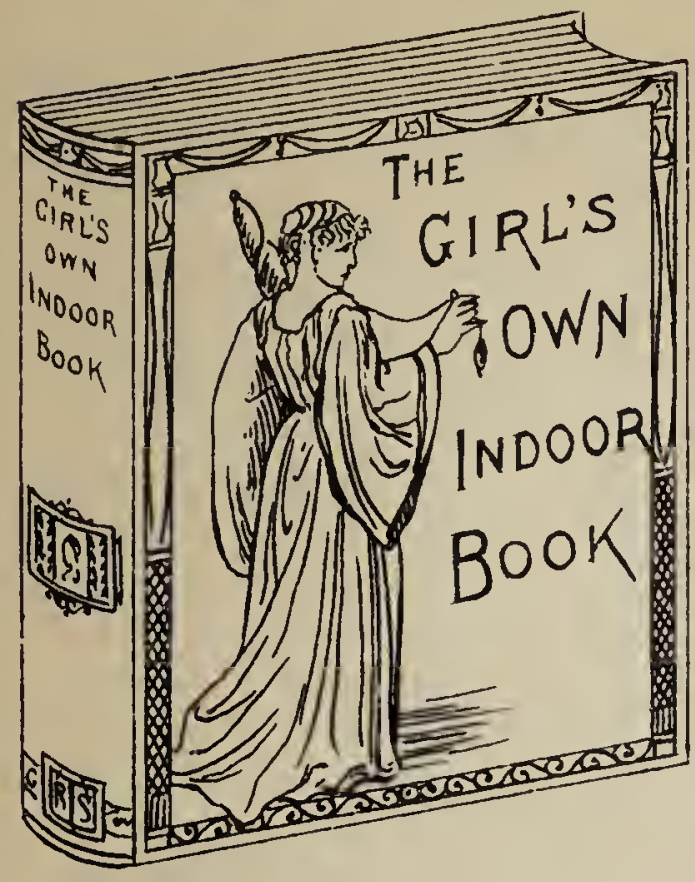

Indoor Games and RecreaTroxis. A popular Encretopertia for Boys. Edited by G. A. Hurcuson. Including ehapters by J. X. Maskeryali, lieut.- Col. Cotheit, 1). Gompon stables. R.N., Rer. A. Ni. Malar, M A., C. Stansfirld - Hicks, 1)r. Straduing, and others. "Boy"s Own Bookshelf." Vol. Vill. With many Engraviugs. Quarto. \$s. cloth boards, gilt edges. A splendid Gift-Book or P'rize for Boys. 525 pages, $8 \frac{1}{2} \times 6 \frac{1}{2}$.

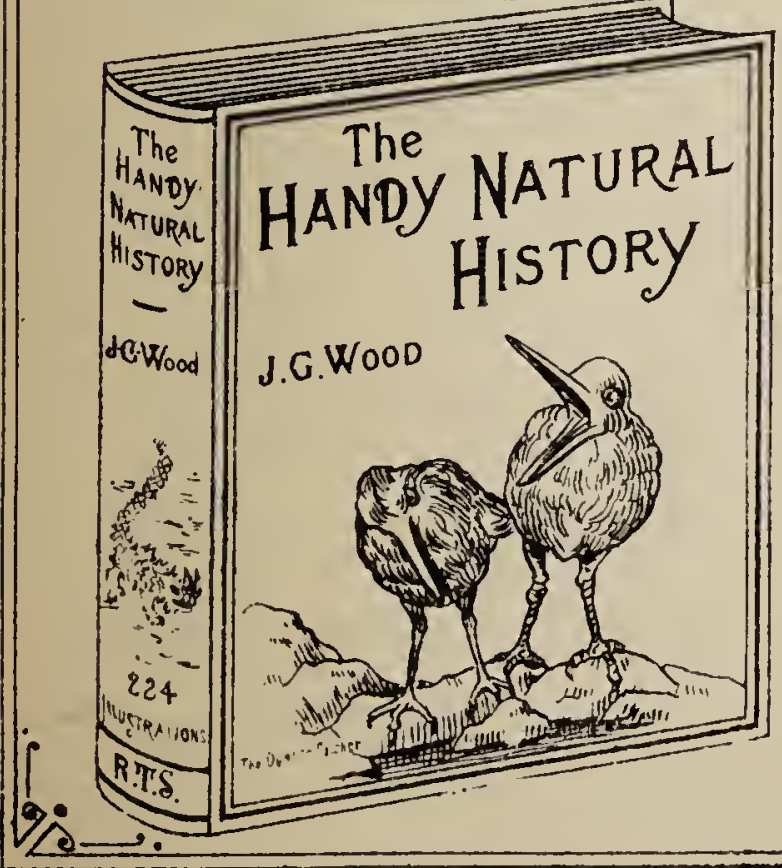

Girl's Own Indoor Book. Edited by CHartes P'ETERs. 528 pages, $8 \frac{1}{2} \times 6 \frac{1}{2}$, With over one hundred and fifty illustrations. Ss. eloth, gilt cdges.

Containing practical helps to Girls in all matters relating to their material comfort and moral wellbeing. By the Author of "IJow to be Happy though Married," Dora de Blaquicre. Dora Hope, Mlarie Karger, Lady Macfarren, Iadr Lindsay, Ernst Paner, Sir John Stainer, the Hon. Victoria Grosvenor, John C. Staples, Canon Fleming, "Medieus," Ruth Lamb, Sophia Caulfeild, and many others.

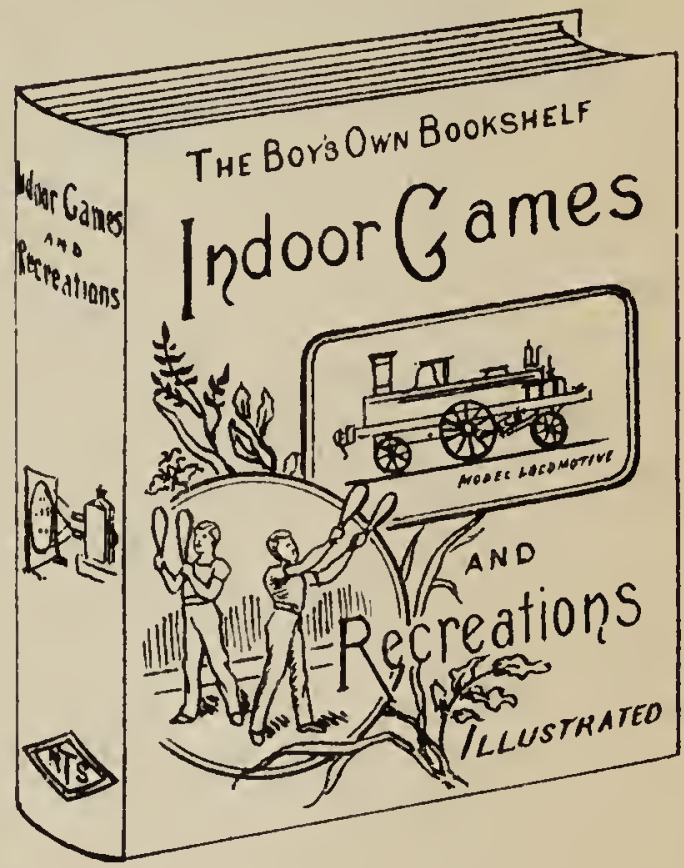

The Handy Natural His'rorr. By the Rer. J. G. Woon, author of "Homes without Hands," etc., etc. 368 pages, $8 \times 6 \frac{1}{2}$ With 224 lingravings. 8s. eloth boards, gilt edges.

"A delightful book, and will make a very handsome and enviable high-class prizc or present."School Board Chronicle.

"A handsome volume, in which the author, a well-known naturalist. tells his reaciers in simple, untechnieal language the liabits and nature of birds, heasts, ard reptiles. Mr. Wood's style is excellently adapted tor attracting the interest and insuring the attention of even ordinarily eareless readers." - Mail. 


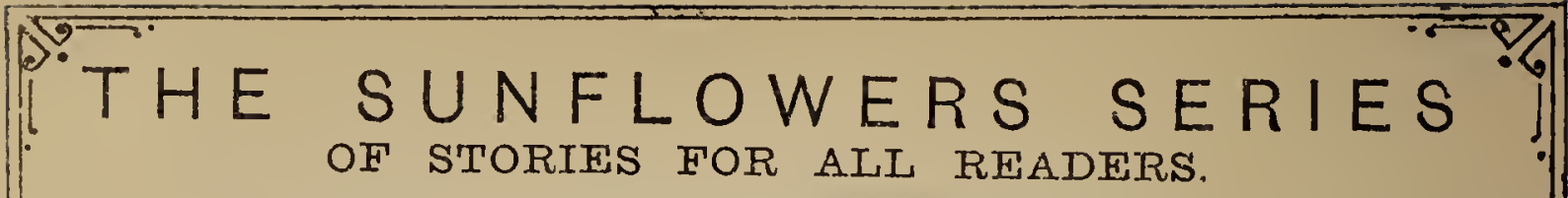

This is a Series of Books intended for adults rather than children. Large numbers of young people, as well as readers of older growth, give up much of their time to fiction. This Sprics supplies books which not only interest as well-written Stories that afford studies of character and descriptions of events and scenes likely to rivet the attention, but which also stimulate the serious thought, and derelop the better nature of those into whose hands they fall.

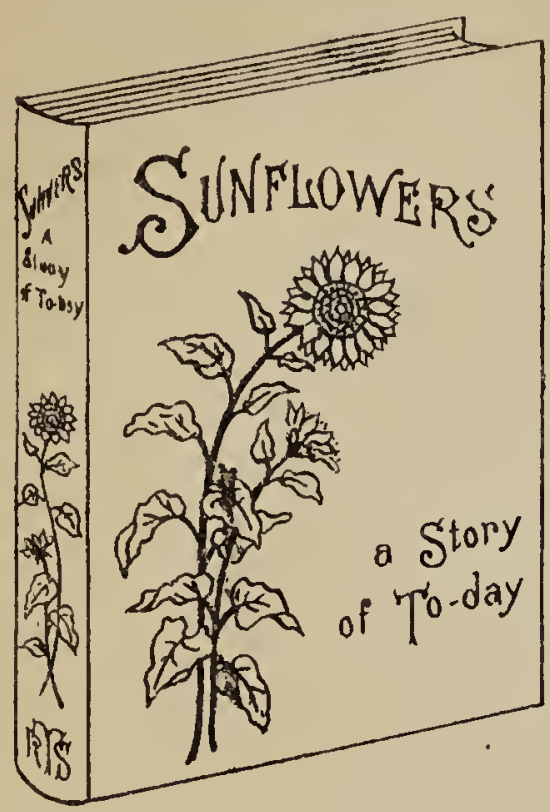

The Manse of Glen Clunie. By EGIANTOx "lionns, author of "The old Worcester Jug," "The Two Crowns," etc. Illustrated br Crarlas WHYMPER, Clown 8 ro. 3s. 6 d. eloth.

Two Enthusiasts. By E. EVERETT GREEN. Illustrated by Huward WhMmper. Crown 8vo. 5s. cloth boards.

Barbara's Brothers. By $\mathbf{E}$. LiveretT Grien, Author of "Lenore Amnandale's Story," "Joint Guardians," ete. Iilustrated by R. and E. TArion. Clown 8vo, 5s. cloth boards.

Joint Guardians. By E. ENhRET Girfen. Illustrated. 5s. cloth.

Joyce Graham's History ; or. Overcoming Eril with Good. BY H. A. Gow RING. Illustrated. Crow11 8vo. 3s.6d.

Another King. By INET EDEN. lllustrated by l. Wuympr. Crown 8 ro. 3s. 6d. cloth.

The Head of the House. A Story of Victory over Passion and pride. B F. E. Grews. Illustrated. Crown 8vo. 5s.

Ida Nicolari. By Eglanton Thorne. Illustrated. Crown 8vo. 3s. 6d.

The Old Manuscript; or, Anaise Robineau's History. A Tale of the Huguenots of La Vendee. By Blasche M. Mogrridge. Hlusirated by E. Whymer. Clown 8 o. 5s. cloth.

Young Sir Richard. By H. Frederick Charles. Illustrated. Crown Sro. 5s. clotli.

Maddalena, the Waldensian Maiden and iler People. Translated by Julie Sutrer. Illustrated. Crowli Sro. 3 s. 6 d. cloth.

Turning Points ; or, 'Two Years in Maud Yernon's Life. By L. C. Srrks. Illustrated. Crown 8vo. 3s.6d. clotli.

Reaping the Whirlwind. A Story of 'Three Lives. Illustrated. Crown 8vo. 3s. 6d. cloth.

One Day at a Time. By BLA NCHE F. M. GRexe. Hlustrater by E. WHYMPR. Crown 8vo. 3s. $6 \mathrm{c}$. clnth.

The Mistiess of Lydgate PrTORY ; or, the story of a Long life. 13y Evelya li. Grese. Crown 8ro. 5s.

The Two Crowns. By Earianton Tunse. With Illustrations. Crown Sro. 3.: firl. eloth.

Lenore Annandale's Story. By Evest F. GReer With llustrations. Clown 8 ro. 5s. cloth.

Carola. By Hespa STRETos. With Tllustrations. Crown Svo. 3s. lid.

Sunflowers. A Story of To-day. Tiy G C. GEDas. Tllustrated. Crown sro. 3s. 6a. cloth.

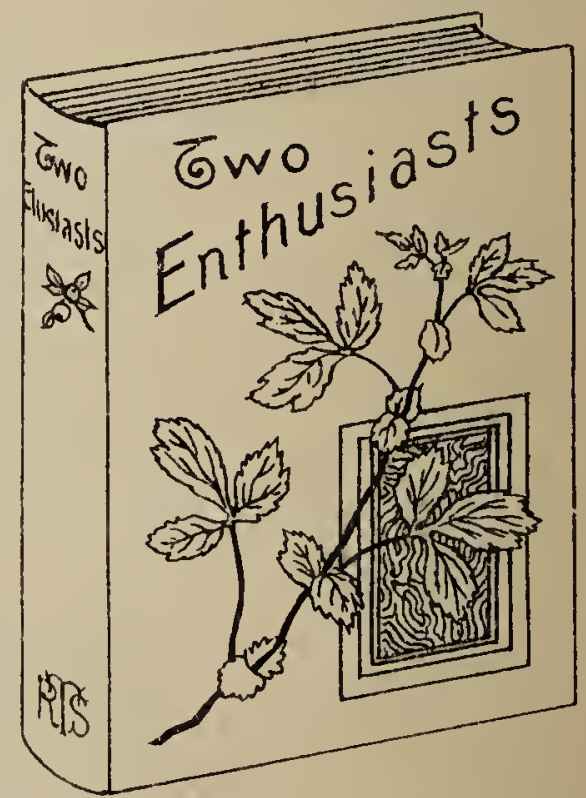



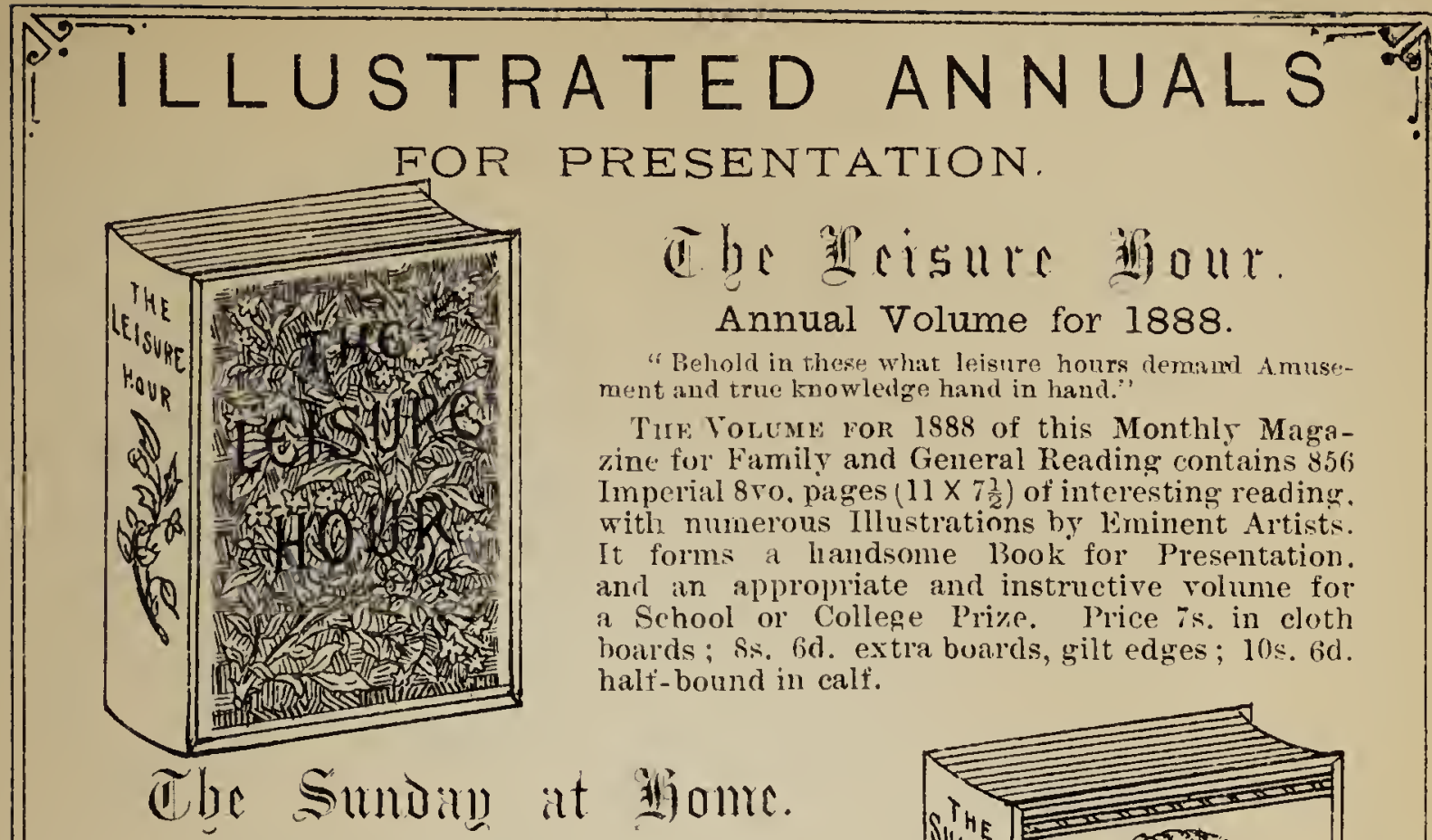

PRESENTATION

Annual Volume for 1888.

\section{AN ILLUSTRATED FAMILY MAGAZINE FOR \\ SABBATH READING.}

THIS VOLWM roR 1888 forms a verT suitable Book for Presentation. It contains 828 pages., Imperial $8 \mathrm{ro}\left(11 \times 7 \frac{1}{2}\right)$, with a great varicty of Interciting and Instructive sabbath Reading for every Member of the Family. It is profusely illustrated by Colourcel and Wood lingravings. Price 7s. cloth hoards; 8s. 6d. extra boards. gilt edges; 10s. 6d. half-bound in calf.

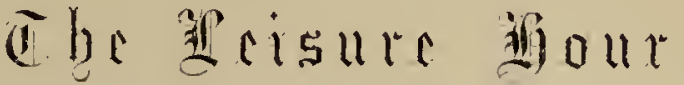 Annual Volume for 1888.}

"Behold in these what leisure hours deminul Amusezinc for Family and General Reading contains Imperial 8 ro. pages $\left(11 \times 7 \frac{1}{2}\right)$ of interesting reading. with numerous Illustrations by liminent Artists. a llandsome l3ook for Presentation. a School or College Prize. Price 75 in cloth boards; s.s. $6 \mathrm{~d}$. extra buards, gilt edges; $10 \mathrm{~s} .6 \mathrm{~d}$. halt-bound in calf.

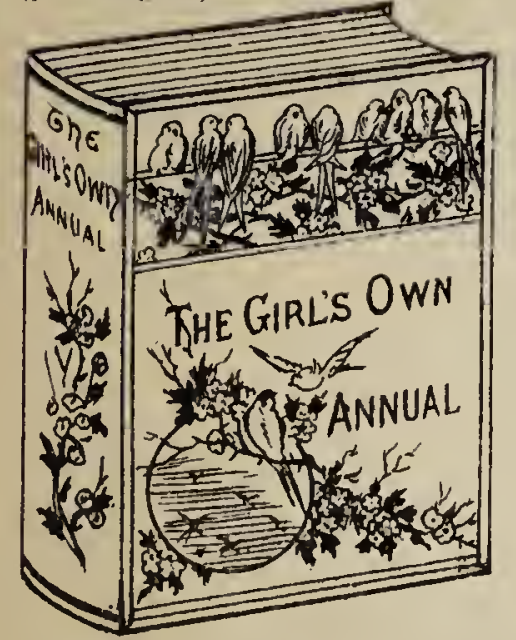

\section{The coitl's (1) Aun Anmual.}

The Ninth Volıme of "The Girl's Own Paper," -containing 848 Demy 4to (11 $\times 8 \frac{1}{4}$ ) pages of interesting and useful reading. Stories by popular writers; Musie by cminent composers ; Practical Papers for Young Housekeepers; Medical Papers by a well-known practitioner; Ncedlework, plain and fancy; Helpful Papers for Christian Girls; Papers on Reasonable and Seasonable Dress, etc., etc. Profusely illustrated. lice $8 \mathrm{~s}$. in handsome cloth; $9 \mathrm{~s}$. 6d. with gilt edges; 12s. 6d. half-morocco.

\section{Che Pou's (Aton 코mual} FOR 1888.

The 'Ienth Annual Tolume of the " Hor's Own Paper." Containing 848 large lages (1133 $\times 8 \frac{1}{2}$ ) of 'Iales of Schoolboy Life, and of Adrenture on Isand and Sca; Outdoor and Indoor Games for every Season; l'erilous Arrentures at Home and Abroad; Amusements for Summer and Winter; and Instructive Papers writtenso as to be read by boys and youths. With many Coloned and Wood Fingravings. Price $8 s$. handsome clotlı; 9s. 6 d. gilt cdges; 12s. 6d. half-moroceo.

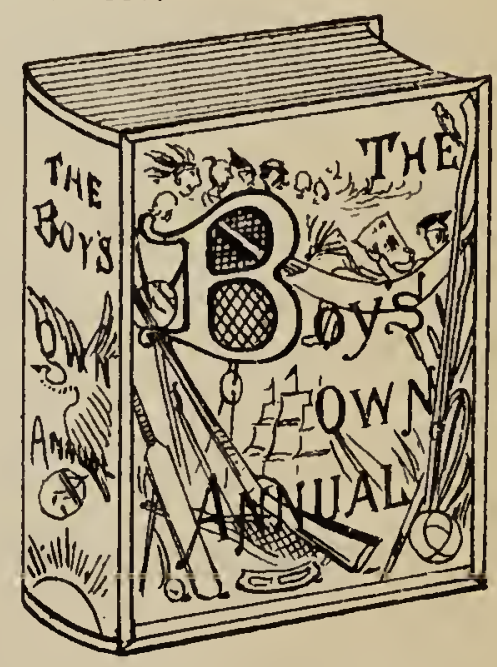




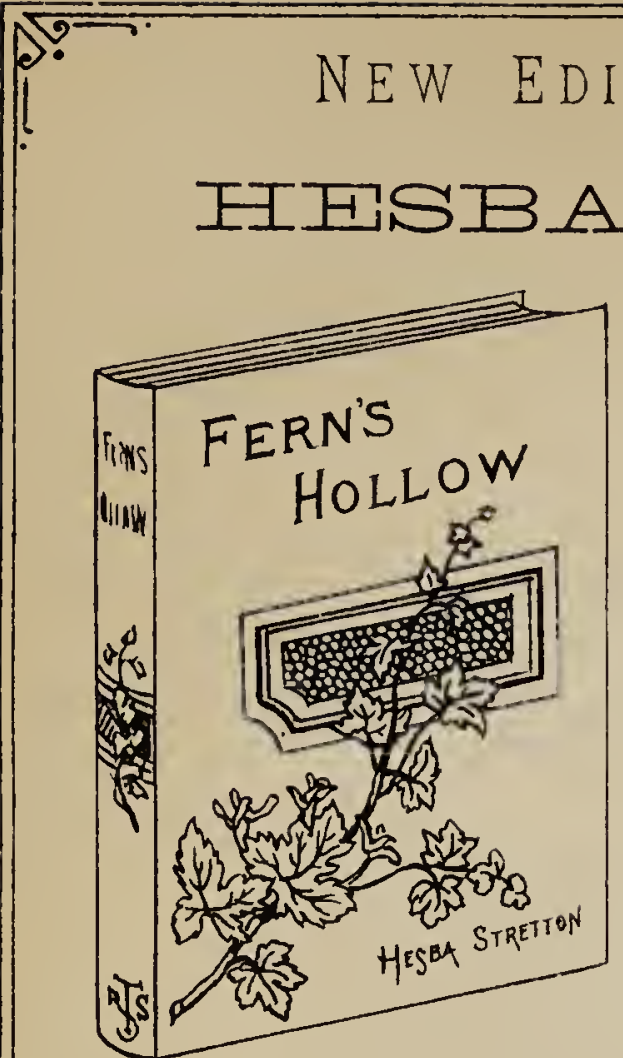

The King's Servants. ${ }^{*}$ Illustrated. 1s. 6 d.

Lost Gip. Illustrated. 1s. 6d. cloth.

Max Kromer. A Story of the Siege of Strasbourg. 1s. 6d. cloth.

No Place Like Home. Illustrated. is. cloth.

The Storm of Life. Illustrated. 1s. 6d. cloth.

A Thorny Path. Illustrated. 2s. cloth.

Under the Old Roof. Illustrated. 1s. cloth.

A Night and a Day. 9d. cloth.

Left Alone. 6d. cloth. A Miserable Christmas and a Happy

The Worth of a Baby. 6a. cloth.

Sam Franklin's Savings Bank. 6d. cloth.

Michel Lorio's Cross. Illustrated. 6d. cloth.

\section{By Mrs. O. F. WALTON.}

Christie's Old Organ; or, Home, Our Gracious Queen: Pictures and Sweet Home. 1s. clotli.

Angel's Christmas. 16mo. 6d.rloth.

Launch the Lifeboat. With 44 Coloured Pictures or Vignettes. 4 to. 3s. coloured cover.

Little Dot. Coloured Frontispiece. 6d. cloth.

Little Faith; or, The Child of the Toy-Stall. 1s, cloth.

Nobody Loves Me. Royal 16mo. 1s. cloth.

Olive's Story; or, Life at Ravenscliffe. 2s. 6il. cloth, gilt edges.

Was I Right? Fine Engravings. Imp. 16mo. 3s. 6d. cloth, gilt edges.

Stories trom Her Majesty's Life. with many pictures. New and Revised Edition. 1s. cloth.

A Peep Behind the Scenes. Imp. $16 \mathrm{mo}$. 3s. 6d. cloth, gilt edges.

Poppie's Presents. Crown 8vo. ls. cloth.

Saved at Sea. A Lighthouse Story. New and cheaper Edition. Is. cloth.

Shadows. Scenes in the Life of an Old Arin-Chair. Imp. 16mo. ts. cloth. gilt edges.

Taken or Left. Crown 8vo. is cloth. 


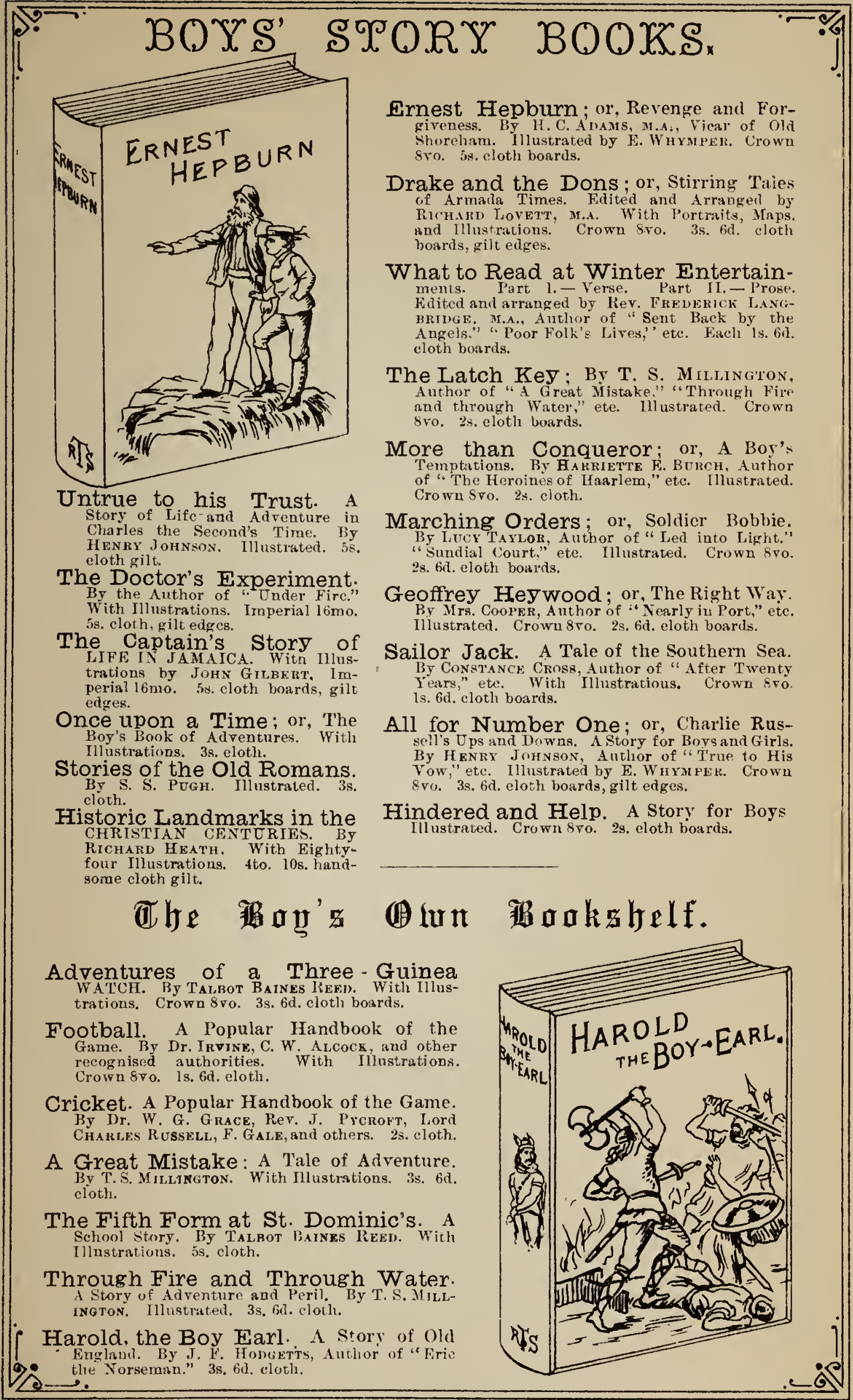




\section{BOOXS IOR GXRXS.}

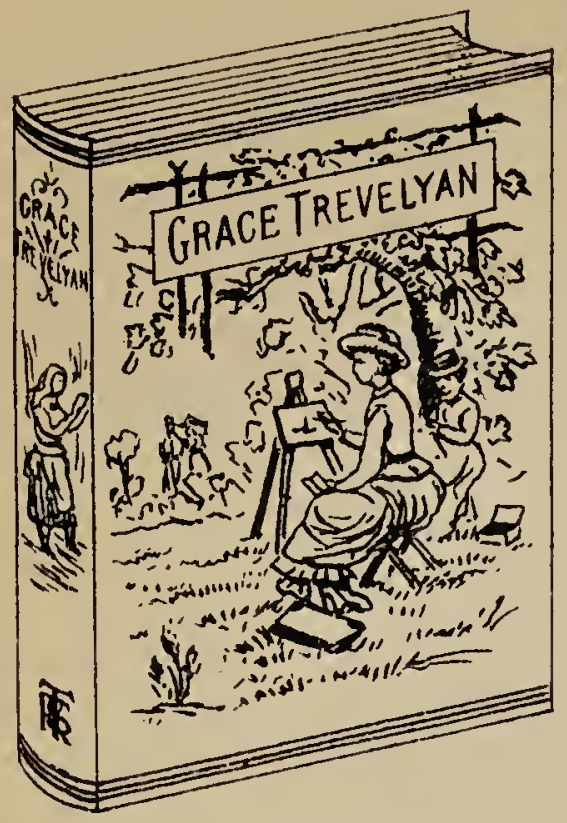

In a Jesuit Net. By A. C. CoApr, Author of "The Chatenu de Louard," ete. llustrated liv EDW sro. 5s. cloth bourds.

Mrs. Morse's Girls. A Story of Ainerican Sumulay Schoul Life, In]ustrated. Grown 8 vo. 3s. $6 d$, cloth boards, gilt edges.

The Heroines of Haarlem. Adapted from the French of Madame de Wit. By HARKIET'E H. Burcis, Author of "Count Renweherg's 'Treason," ete. With Illustrations. Crown 8vo. 3s. 6r. eloth, gilt elges.
Grace Trevelyan; or, Ied into Lig'ut. By Mrs. Coots, Aulhor of "The Sure IIarvest," "The first Gift." ett: Hhustrated hy E. WHYMPER. (irown 8ro, 3s. 6u. cloth boards, gilt erlyes.

May. "a Succourer of Many." By Miss A. G. GRAY-Jones. With fllustrations. Crown sro. 2s. aloth bourds.

Dorothy Tresilis. A Colnish Tale. By M. M. Polland, Aluhor of "lilla's Experiment," "Only Me." atc. Itlustraterl. Crown 8vo. Is, in cloth boaris.

Miss Elsie. A Story of Single-hearted Service. By H. MAKY WIsson, Illustrated. Crown 8vo. "2s. bil. clotl boards.

"Therefore," or Nessie's Ideal. A Story for Girls. By FuOBENCE E. BURCH, author of "Joseph Adims;" Etc. Il]ustrated. Crown 8vo. 2s. elotlı boaris.

John Richmond's Mistake. Br JAx EuEN, author of "Hester's Home:" "Another king," etc. Illustrated. Crown svo. 2s. bd eloth boards.

Higher Üp. By NeLitr: HFilis, Author of "Three Little Fidalers," "Rosing Rolbin," "Gipsy Jau," etc. etc. Illustrated. (rown 8vo. 28. cloth hoards.

Hope Reed's Upper Windows. By HOWF B HExist. 3s. bid. cloth gilt.

Dolly. A Quiet Story for Quiet People. By if. $\mathrm{F}, W$. Illustrated. Crown svo. 1s. 6d. clotlı boards.

Every Day. A Story for Sunday Afternoons. By Evely R. EArRali. rllustrated. Crown 8vo. is. 6d. eloth boards.

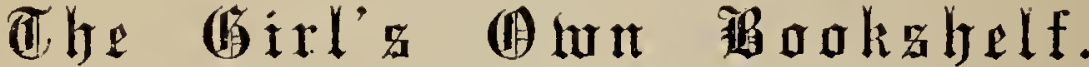

Aunt Diana. By Rosa Novchette Carey, Author of "Not Like Other Girls," "Esther Cameron's Story," ete. Illustrated. Tomerial 16roo. 2s. 6d. berelled boards. Miss Carey is well known as an able and graceful writer of stories for girls. This one illustrates the working of duty founded unon Christian principle.

Cora; or, Three Years of a Girl's Life. Illustrater. Imperial 16mo. 2s. 6d, eloth.

The Girl's Own Cookery Book. By PHILLIS IBRWNE. Feap. 8vo. is, cloth.

'The Queen o' the May. By Answ BFAL.E. Illustrated. Imperial 16mo. 2s.6d :loth.

The Master's Service. A Practical Guide for Gir]s. Illustrated. [mperial $26 \mathrm{mo}$. 2s. 6à. cloth.

How to Play the Pianoforte. Fcap. fro. ls. Gd. cloth. M. Avi. Illustrated. Imperial 16mo. 2s. 63, eloth.

The Sunbeam of the Factory, and other Stories. Illustrated. Imperial $16 \mathrm{mo}$ 2s. fid. eloth.

Esther. By Rosa Novchetre Carfy. Illustrated, Imporial 16mo. 3s. bd. eloth,

The Shepherd's Fairy. By Daniey Datw, Aluhor of "The Great Ank's Egres," Illustrated. 2s. til. cloth

Servants and Service. By Rutu Lami, A uthor of " Comforrable Mrs. Crook," ete. Is. Go choth boalles.

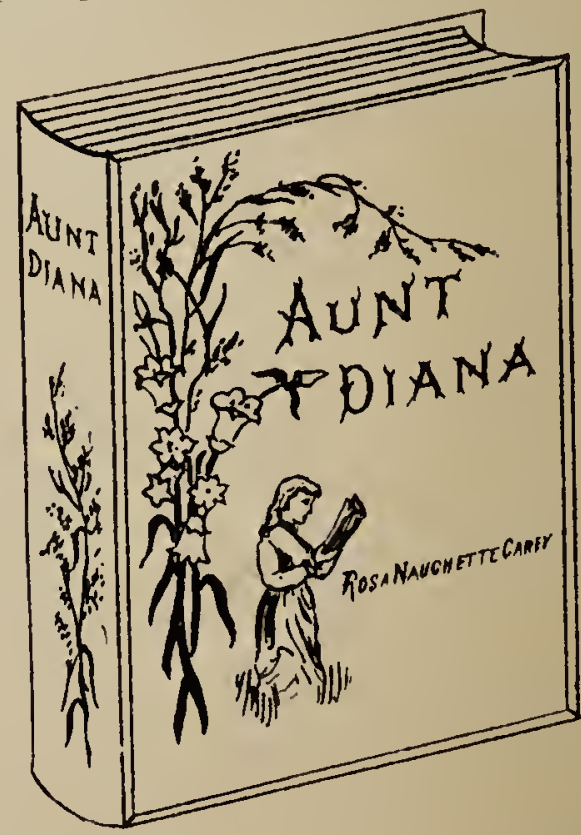




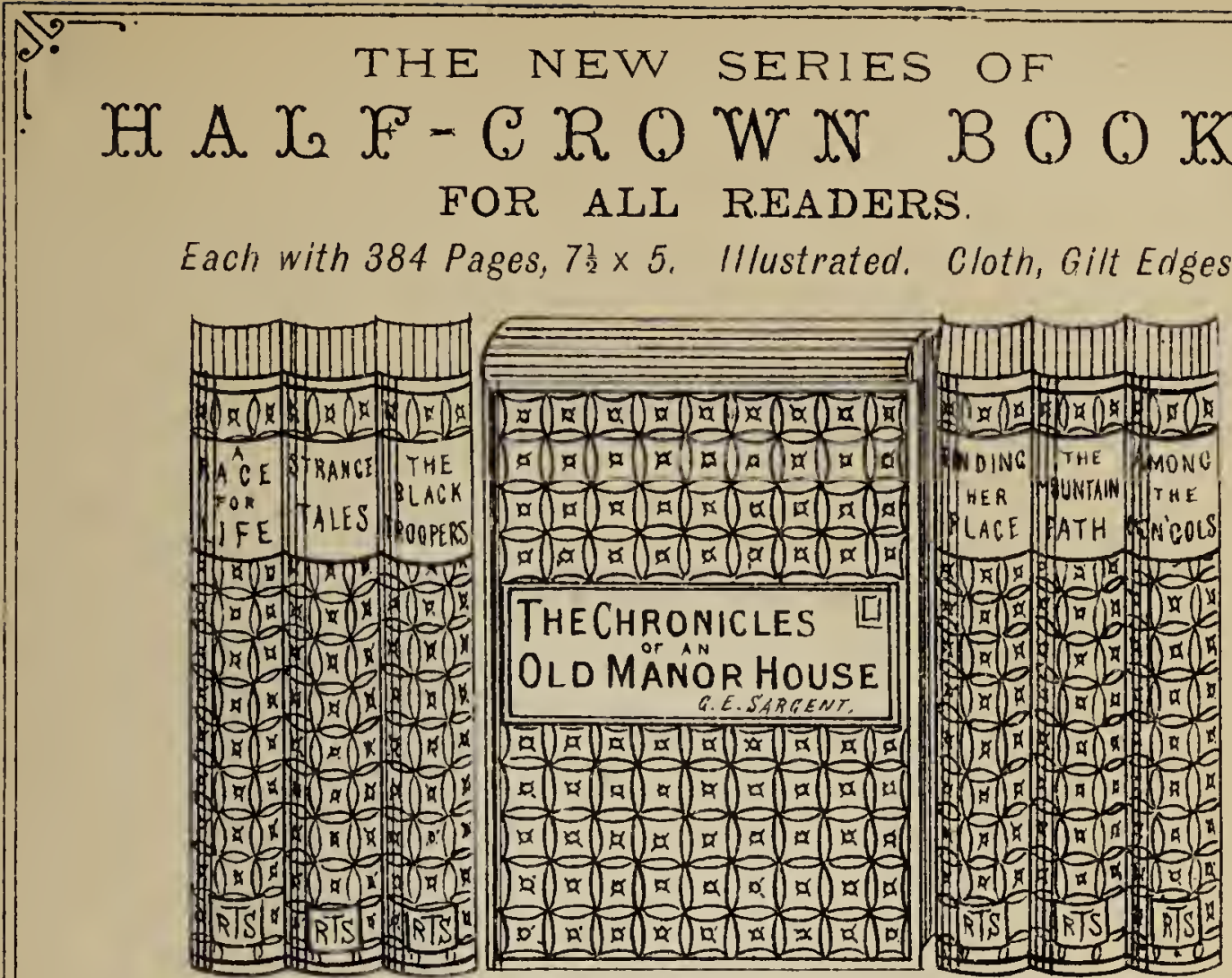

Chronicles of an OId Manor House. By the late G. E. SARGixt, author of "The Story of a locket Bible," etc. 2s. $6 \mathrm{~d}$.

A Race for Life, and other 'Tales. 2s. 6d. cloth, gilt edges.

Strange Tales of Peril and Adventure. Illustrated. 2s. $6 \mathrm{~d}$. cloth gilt.

Remarkable Adventures from Real Life. Illustrated. 2s. 6 d. cloth gilt.

The Black Troopers, and other Stories. Illustrated. $2 \mathrm{~s} 6 \mathrm{~d}$. cloth gilt.

Adventures Ashore and Afloat. Illustrated. 2s. 6id. cloth gilt.

Finding Her Place. By Howe Bennina, Author of "Quiet Corners," "Lrsula's Beginnings," etc. Illustrated. Crown 8vo. 2r.6a. cloth gilt.

The Mountain Path. By LiLY WATsox. Anthor of "Within Sight of the Snow," ete. Illustrated. Crown 8ro. 2s. 6d. cloth gilt.

Among the Mongols. By Rev. J. Gilmour. Mlustrated. 2s. 6d. cloth gilt.

Within Sea Walls; or, How the Dutch kept the Faith. By G. E. SARGExT. Illustrated. 2\%, 6d. cloth gilt.

The Story of a City Arab. With Portrait and Memoir of the Author, the late G. E. SarGerT. 2s.6d. eloth gilt.

\section{A PRETTY PRESENT}

Morning and Evening. Keble's Morning and Evening Hymns. Beautifully illustrated from sketches by J. (nakl, J. H. HIPSI.EY, JAvidson

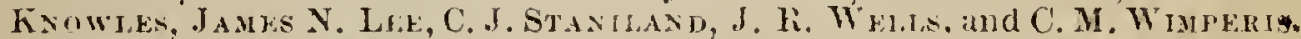
l'rinted in colour by ALFRs Cooks. In a handsome colonred cover, tied with ribbon. Squale $16 m 0$. 1 s.

\section{COLOURED BOOKLETS}

Signals for the Voyage of Life and Heavenly Graces With Verses ly Maky L. Kopks.

Two attractive little coloured books, each consisting of twenty-tour pages, with a cover. 'The Texts are given in illuninated letter's, and the Fersen are from the practised pen of Miss kopes. The booklets are finished with gilt edges, rounded comers, and tied with ribbon. 6d, each. 


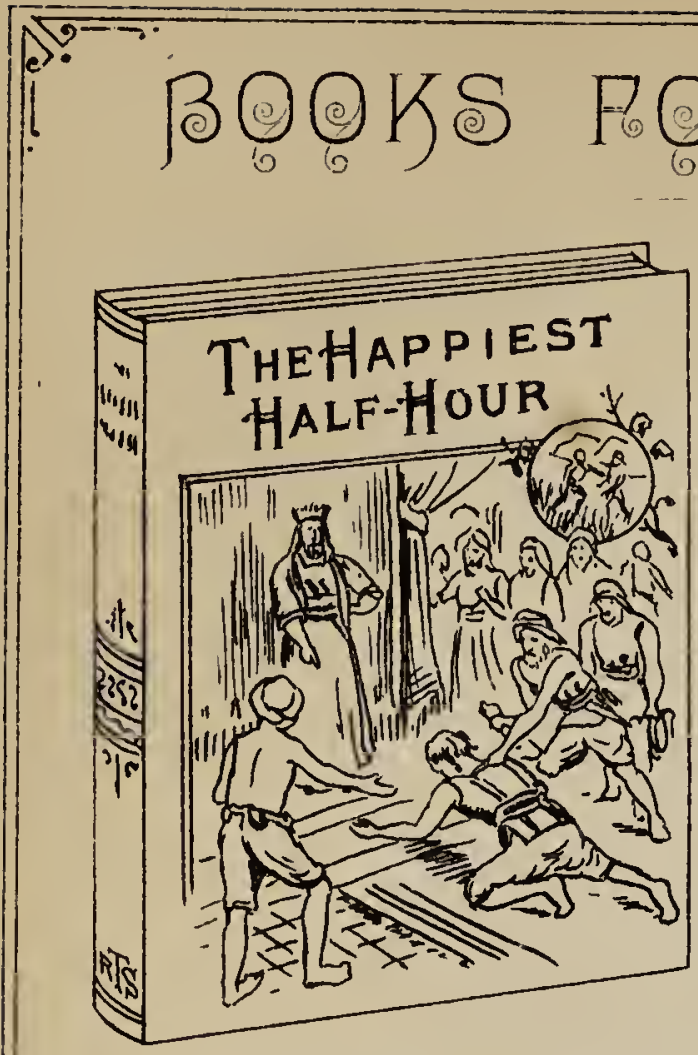

R GILAREA.

The Happiest Half-Hour; or, Sunday 'Lalks with Ghildren. By Frenersck LaNGHende, M.A. With many Illustratious. Small quarto. 3s. 6il cloth boards, giit edres.

The Sweet Story of Old. A Sunday Buok for the Lit.tie ouez. By Hesra ST kerrov Auttior of "Jessicn's First Pray"r," "Bede's Charity," rete. With Twelve Colourer Pietures by L. W. Mannox. 4to. 3s.6ule eloth bonrds, colonred riges.

Watts's Divine and Moral Songs. New Fdition. With many fiue Coloured Illustratious by Fonert Barnks, Gordon Browne, R. W. MALDOX, and J. L. LEE. 2s, 6d. eloth boards.

My Holiday Picture-Book. Comprising : Holiday'Time in the Conntry-Contented Johnnic-The Children of the Bible-The Bnsy Farm ; or, a Visit to our Couutry Friends-Amy's Birthray Present-The Bible Picture Alphabet. With Coloured Pietures. 2s.6d, cloth.

My Coloured Picture Story-Book. With Twouty-four full-coloured page Pictures aud Forty Vignettes. Comprising: Our Pretty Village-Little Antoine and the Bear-Rosa, tlic Little Cousin from India-The Blackbird's Nest. 4s. handsome cloth gilt.

Bible Stories and Pictures. With Twenty-four Coloured page Pictures and furty Vignettes With simple letterpress in large type. As. landsomely bound, cloth gilt.

Harrison Weir's Pictures of Birds and other Family Pets. With 24 large Colon red Pictures. 5s. lrandsomely bound, with side in Gold and Colours.

Storyland. By Sinney Gury. With Thirty-two Illustrations by RoBerT BARSES, Fngraved and Printed in Colour by EDMUSD EVAss. 6s, handsomely bound in coloured puper boards.

Our Pets and Companions: Pictures and Stories Illustrative of Kindness to A uimals. By MarY K. MAn'Tr, A Athor of "Fruits of Pible Lands," ete. Profusely Illustrated hy Wetr, Staces, Whymper, M. E. EDWards, 1. G. BritTain, aud others. Small 4to. 2s. clotll buards.

Talkative Friends in Field, Farm, and Forest. By Marr E. Ropes, Author of "Tom's Beunie," "Till the Sugar Melts," ete. Profusely Hllustrated. A similar Volume to "Our Pets and Companious." Small 4to, 2s. eloth boards.

Little Dot and Her Friends. With Twenty-four Coloured P'ietures and Forty Viguettes. 4s. eloth boards gilt.

Launch the Lifeboat! By Mrs. O. F WaLTON, Author of "Cliristies old Organ," ete. With Coloured Pictures and Vignettes, from Drawings by H. J. Ruoves. Beautifully printer in Colonrs. 4to. 3 s. in attraetive boards.

Sunday Afternoons at Rose Cottage. Bible Talks with Mamma. By Mrs. Waterworth, Author of "Blessings for the Little Ones" etc. in very large type. With Jlustrations, is. 6d. clotli gilt.

Listening to Jesus. A Sunday Book for the Little Oncs. By E. M. WATERWORTH. With Illustrations by W. S. STACEY. Small 4t.o. 1s.6d. cloth boards, gilt edges.

Children's Daily Bread. A Picture, Text. and Verse for Every Day of the Year. 2s. 6a. cloth.

Rible Tales for Children. With Forty full-page Illustrations. Small 4to. 3s. 6d. cloth be velled boards, gilt edges.

Stories of Bible Children. A New Sunday Book for very Little Childreu, Br Mrs. E. M. Waterwonth. In very Jarge type, With llustrations. Sinall 4to. 1s. fid. cloth hoards, gilt eilges.

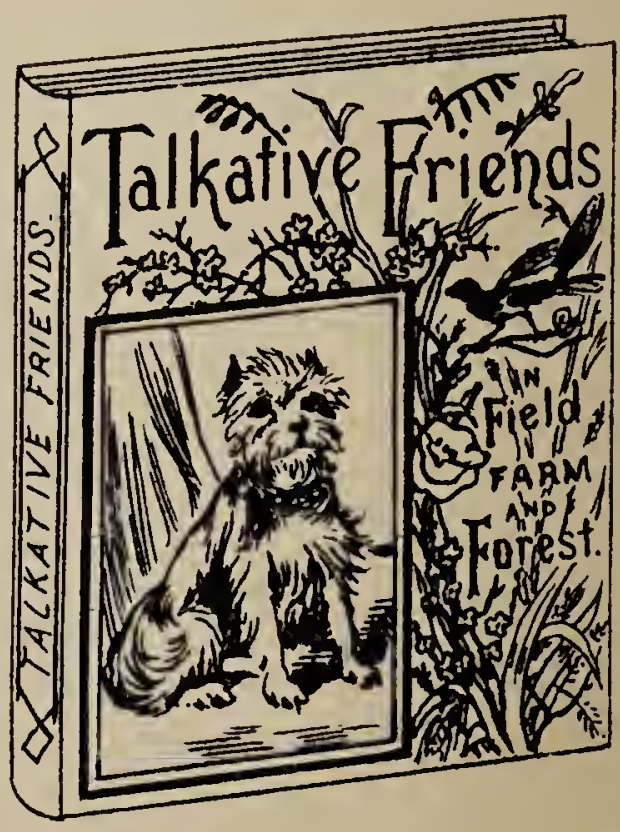




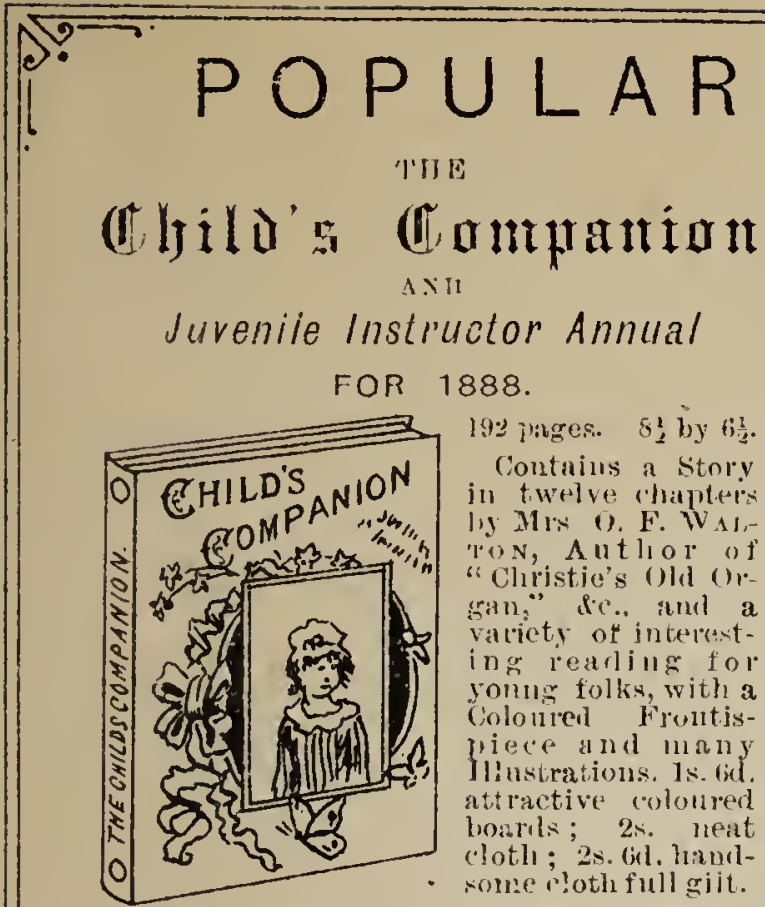

\section{ANNUALS.

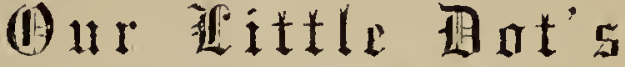 Annual for 1888. \\ 192 pages. 83 by bit.}
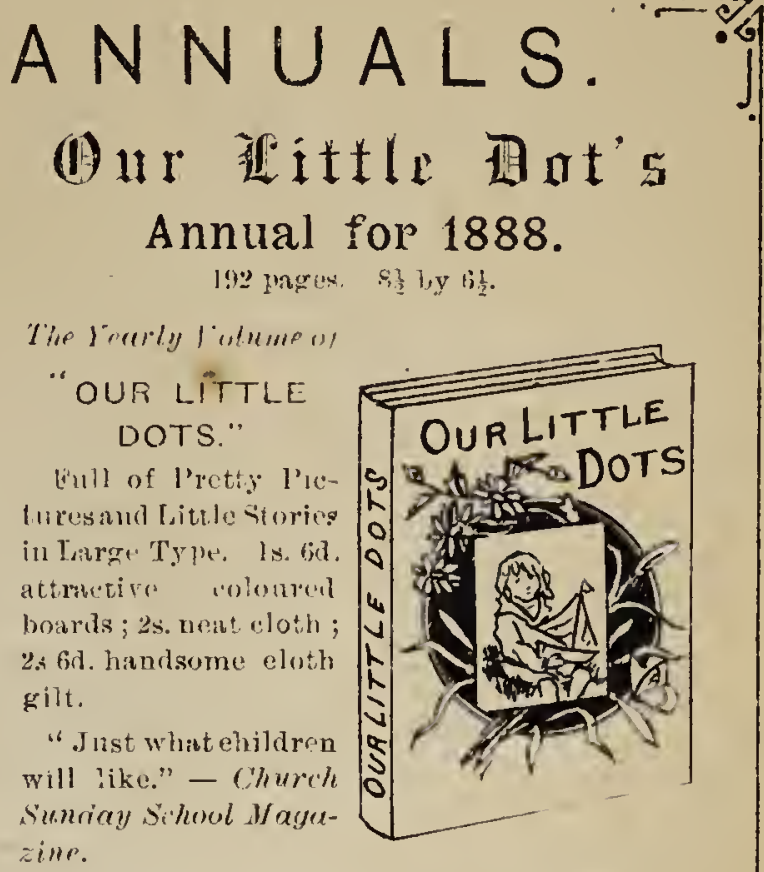

\section{(II) (U) ottager and Artían Annual. THE VOLUME FOR 1888.}

\footnotetext{
It contains 144 puges of interesting readingandillustraticus. A most suitable brok (.) preselet lu tle Workmen's Institute, Club, or Rending lionn, aud for the Home Rearling of Working People in 'lown and (isuntry. Niny Large Pictures, forming yrutea fimily scrap-look. Much of the letterpress is in large type. 1... 6id. in pretty coloured rover; 2s. bil. cloth boards grilt.

>ize of page $1: 3 y_{2}$ by 10.
}

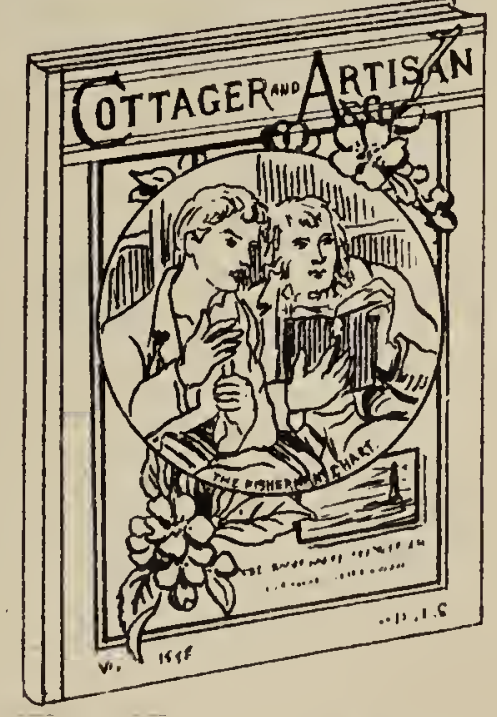

"Telling picturesand pra"tiral articles. We ouly wish that any praise of ours might increase the eireulation of a most vaimable perioulical." The Times.

"A large amount of gool reading for those wlio lave little time or opportunity. The type is large and clenr, and the Illustrations numerous and good." - Scottinh Leacier.

"A weleome addition to the liomes of the working riasses."-Western Mornina Ners.

\section{(alik Tract flanaritti Annual for 1888.}

\section{Grienty Gretting.}

ILICLSTRATED READINGS FOR THE PEOPLE.
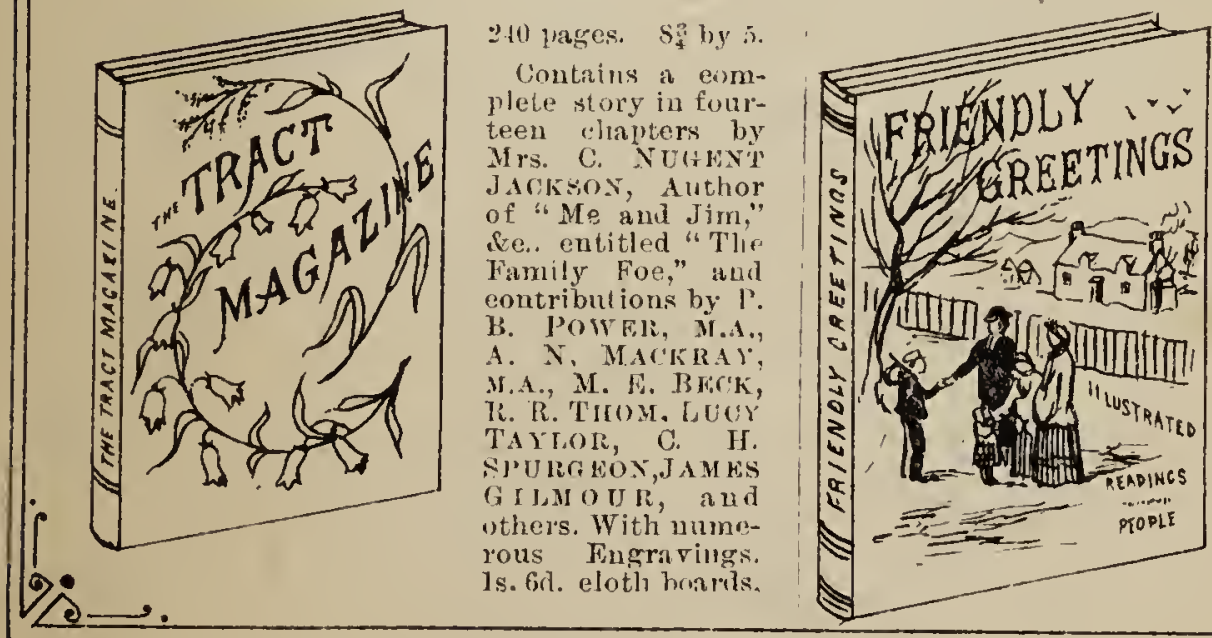

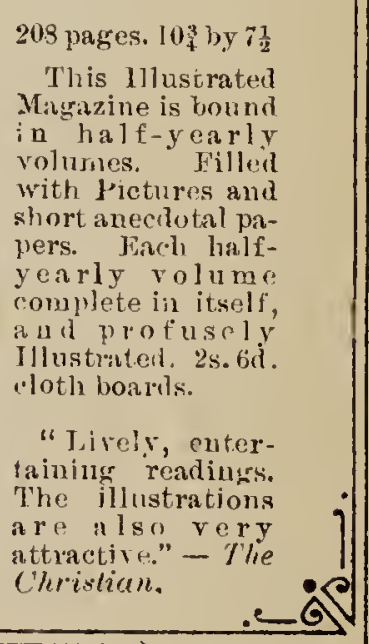




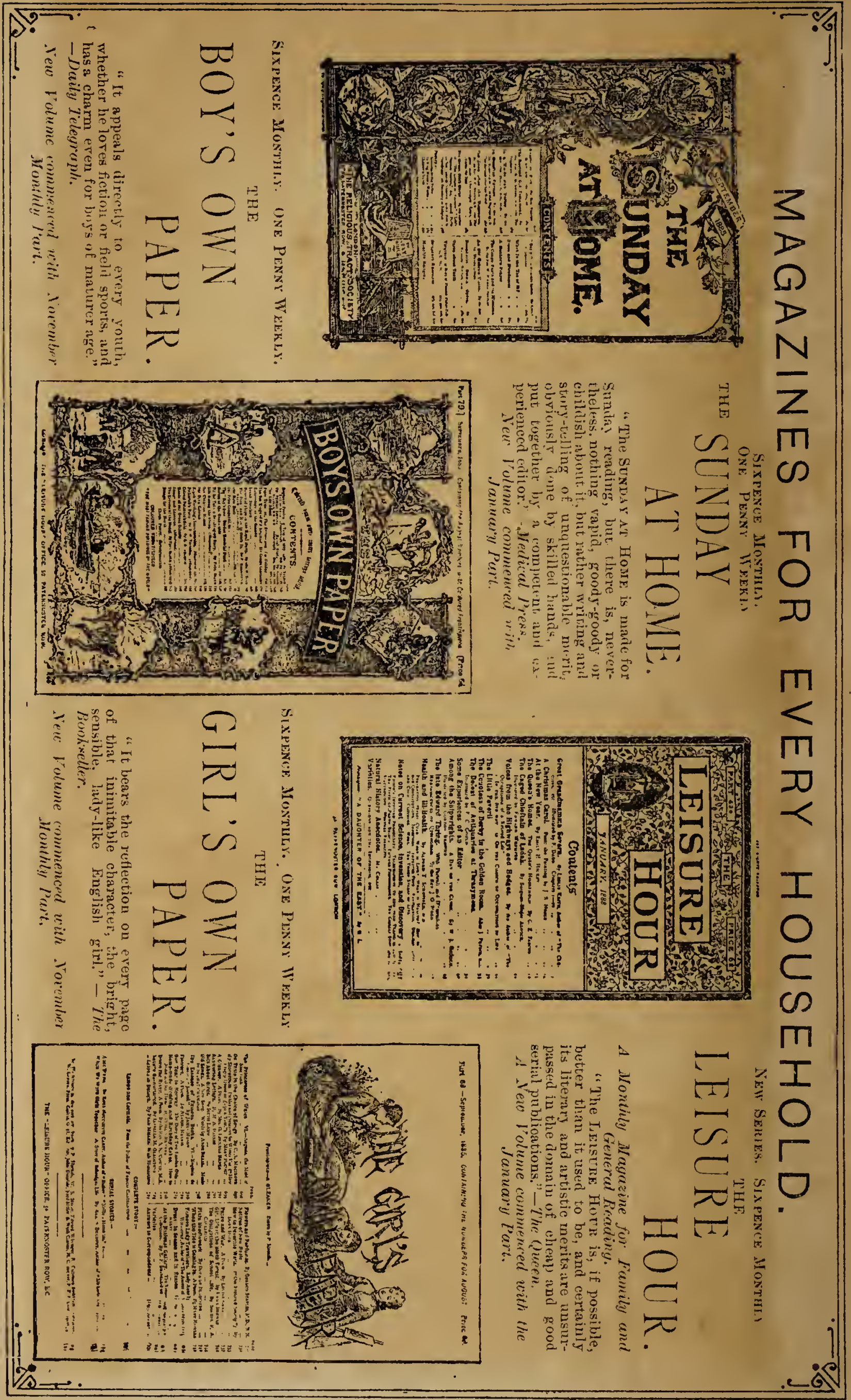




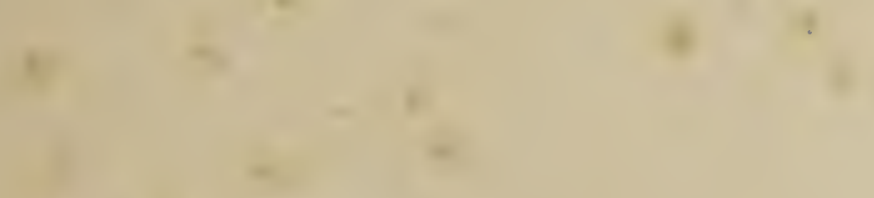

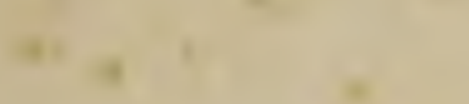
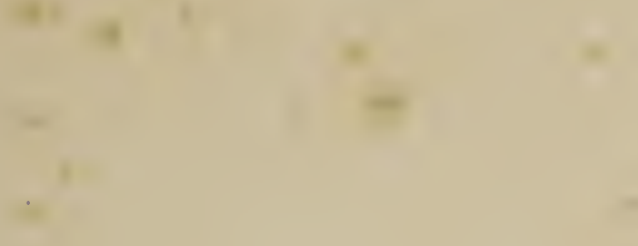

.

+

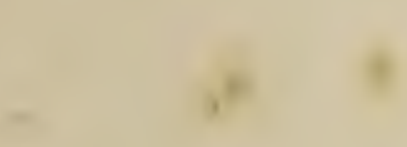




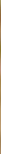

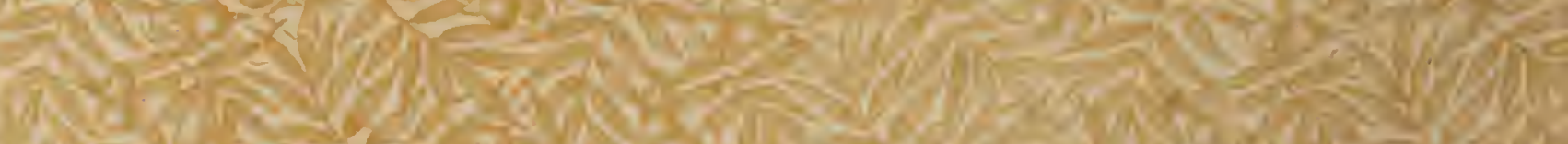

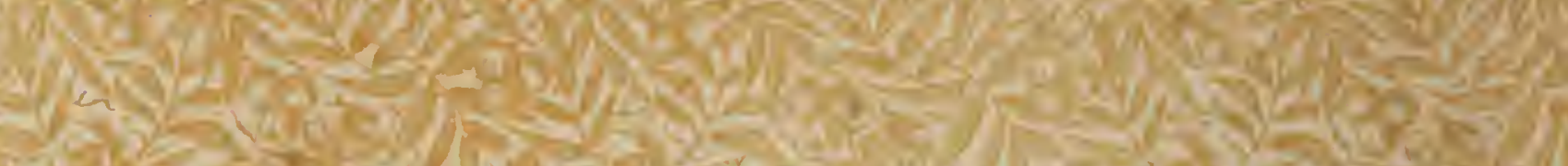

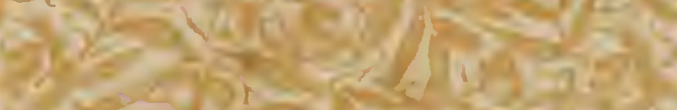

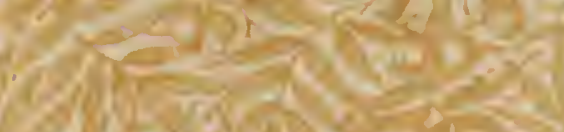

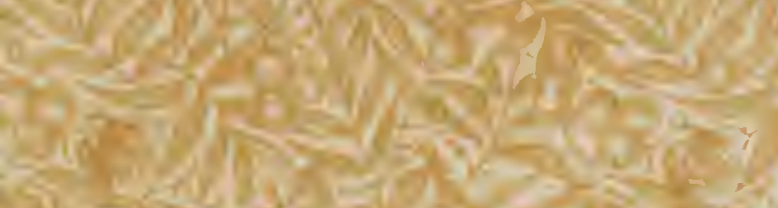
T.

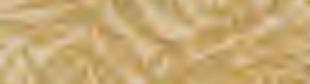

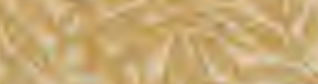

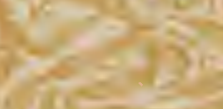

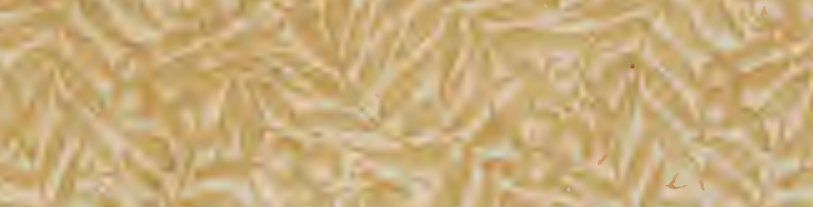

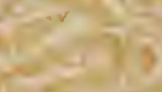

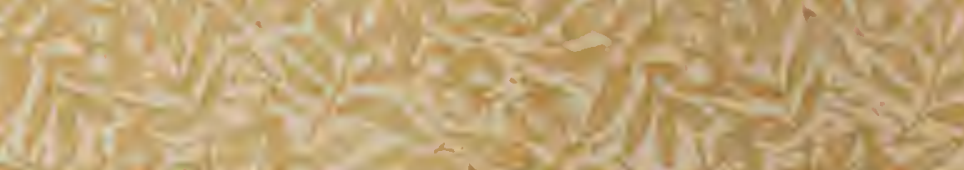

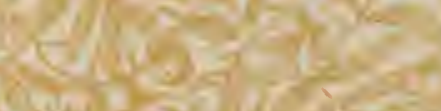

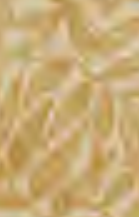
and oringer $\frac{13}{2} \times 10$

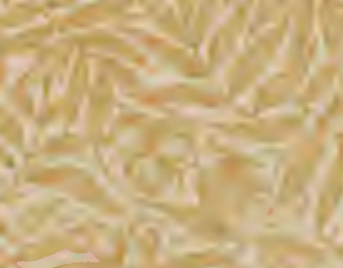

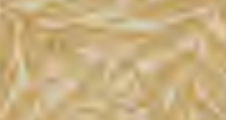

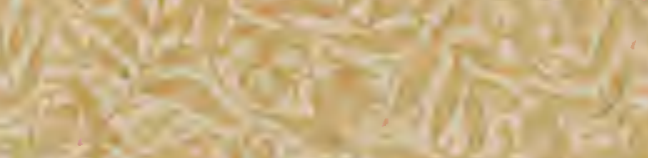

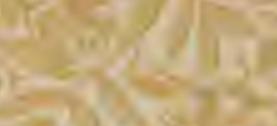

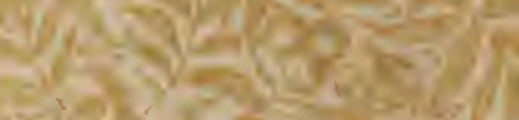
$1,9050=43$

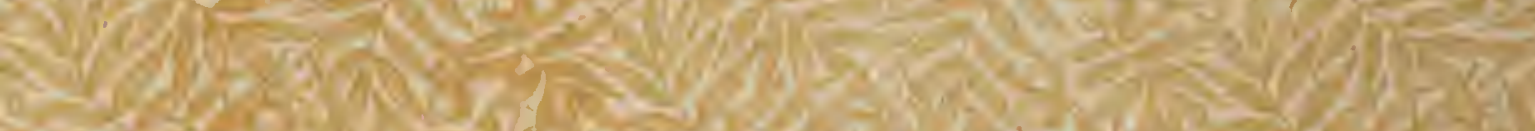

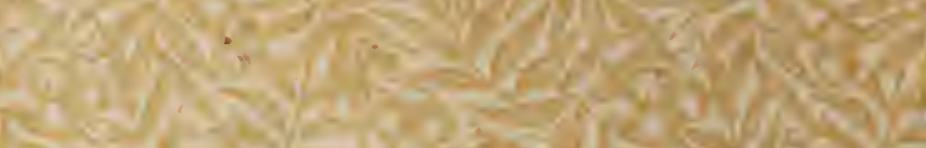

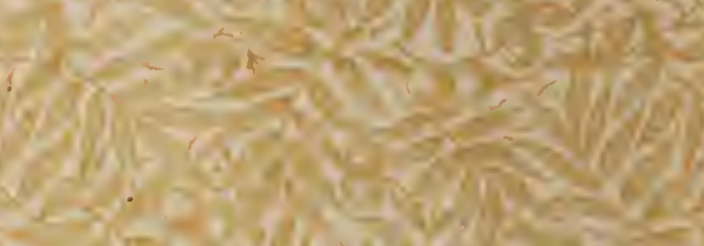

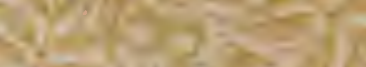

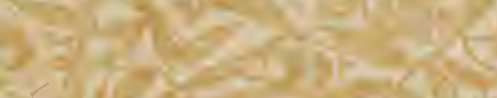




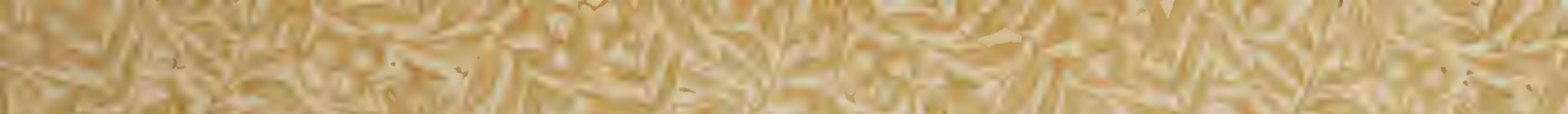

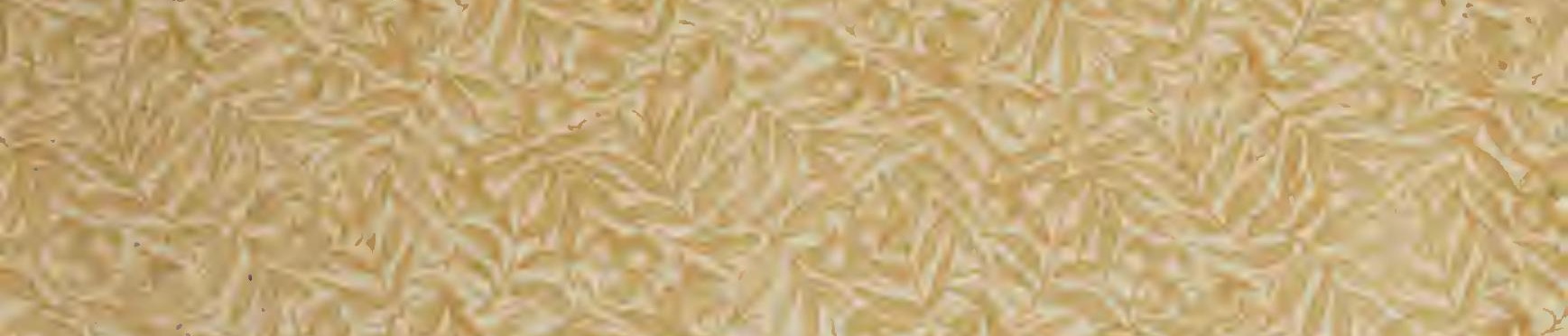

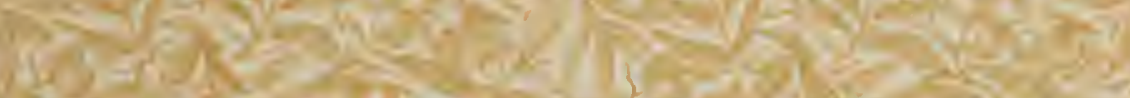

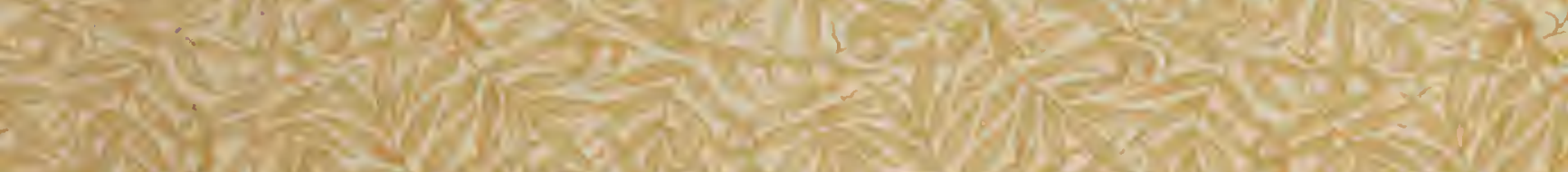

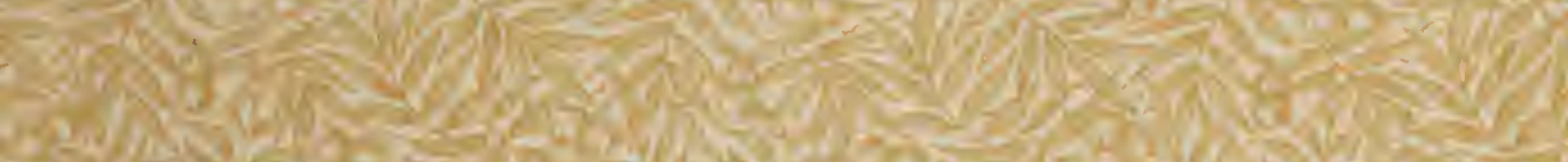

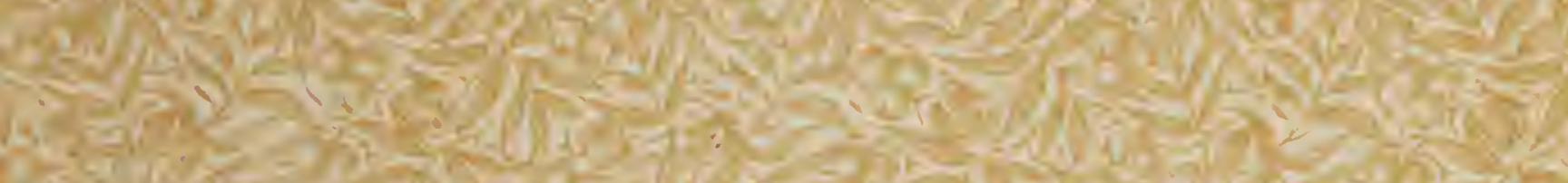
Wis

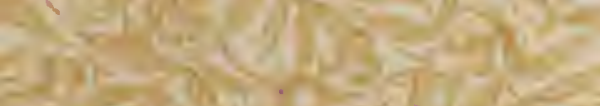

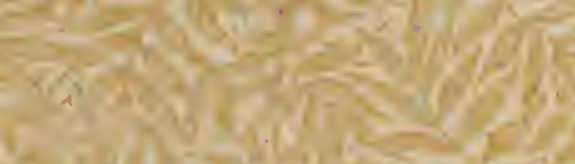

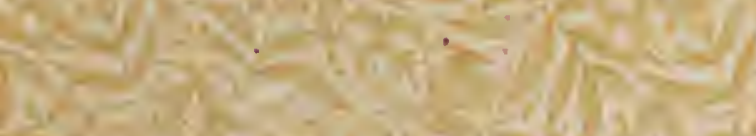

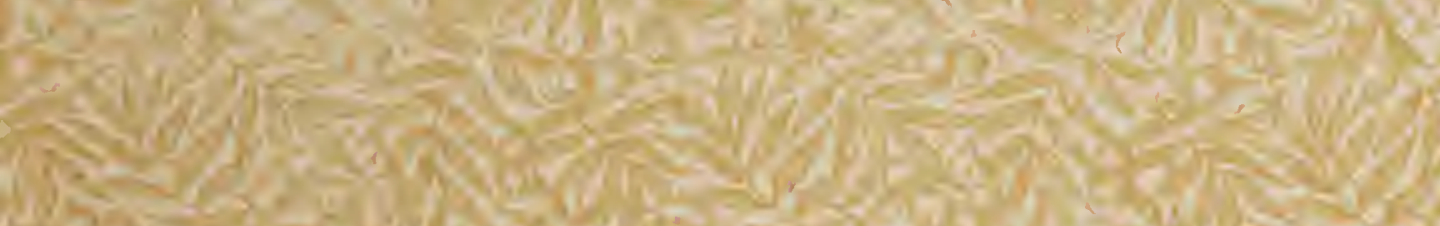

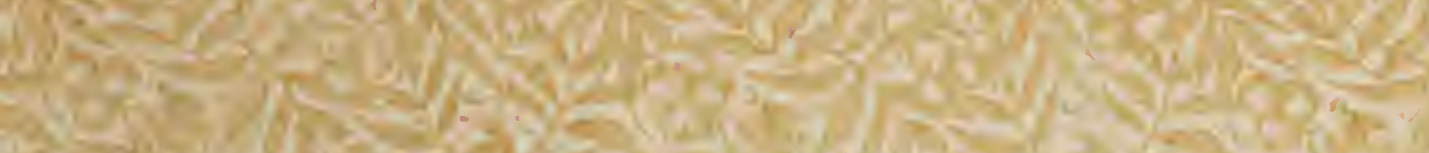

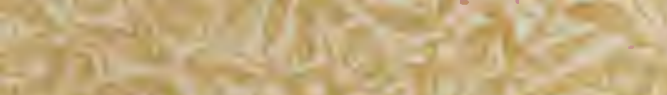

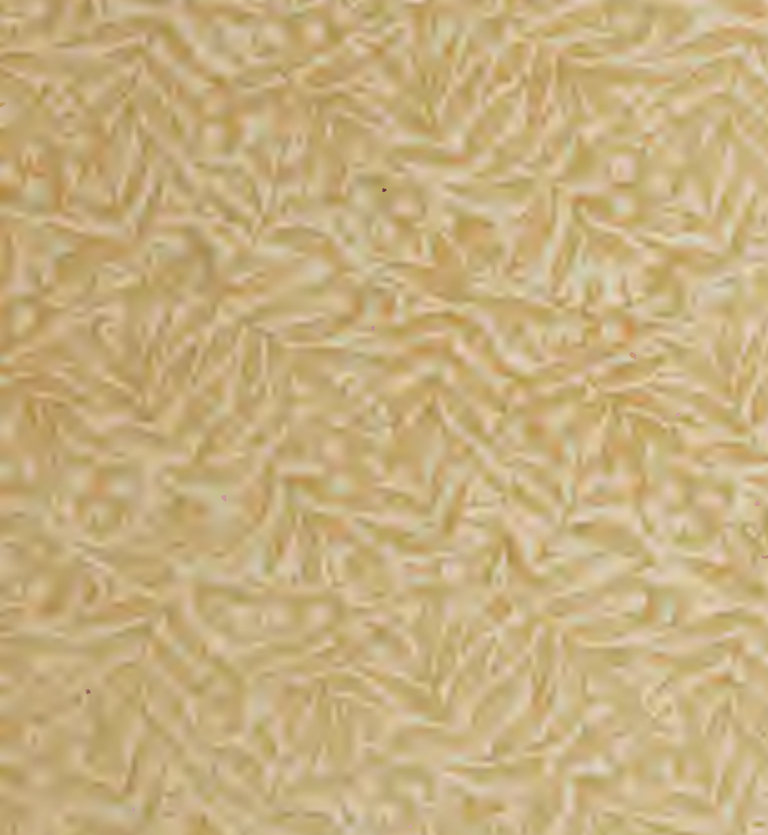
12

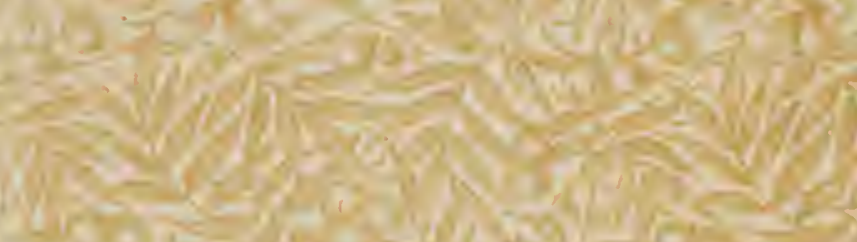

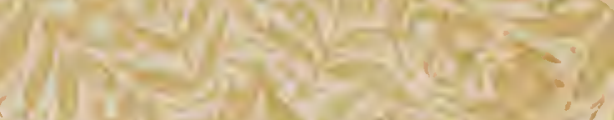


w.

$\therefore=y$

45.

$=$

$-110$

पर

4

$x$

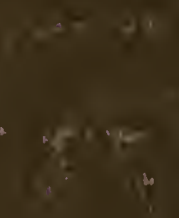

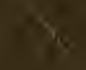

4

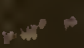

a

B

ain 4 